Fall 1921

\title{
1921 Cedrus Yearbook
}

\section{Cedarville College}

Follow this and additional works at: https://digitalcommons.cedarville.edu/yearbooks

Part of the Higher Education Commons, Organizational Communication Commons, and the Public Relations and Advertising Commons

\section{Recommended Citation}

Cedarville College, "1921 Cedrus Yearbook" (1921). Yearbooks. 91.

https://digitalcommons.cedarville.edu/yearbooks/91

This Book is brought to you for free and open access by DigitalCommons@Cedarville, a service of the Centennial Library. It has been accepted for inclusion in Yearbooks by an authorized administrator of DigitalCommons@Cedarville. For more information, please contact digitalcommons@cedarville.edu. 


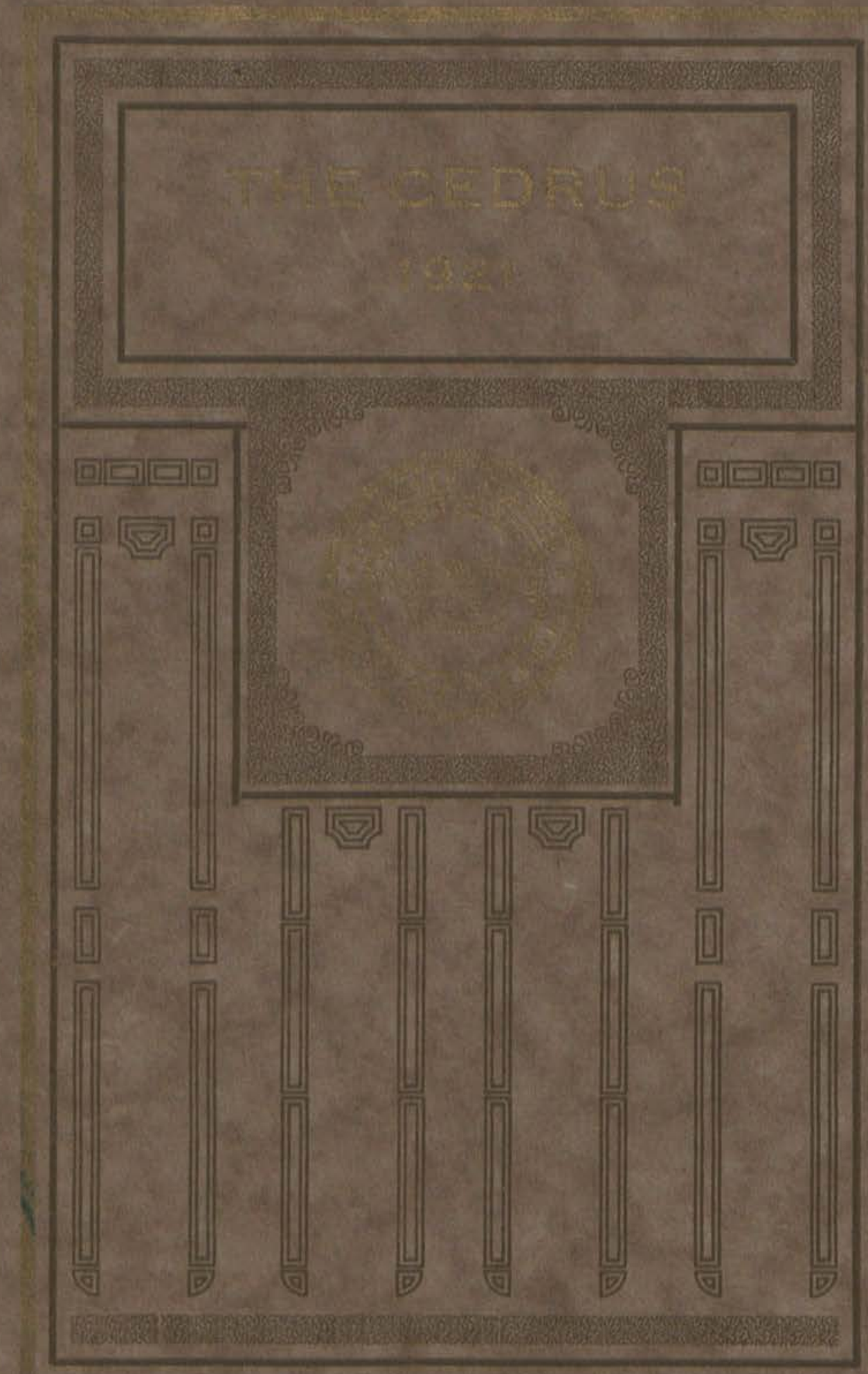




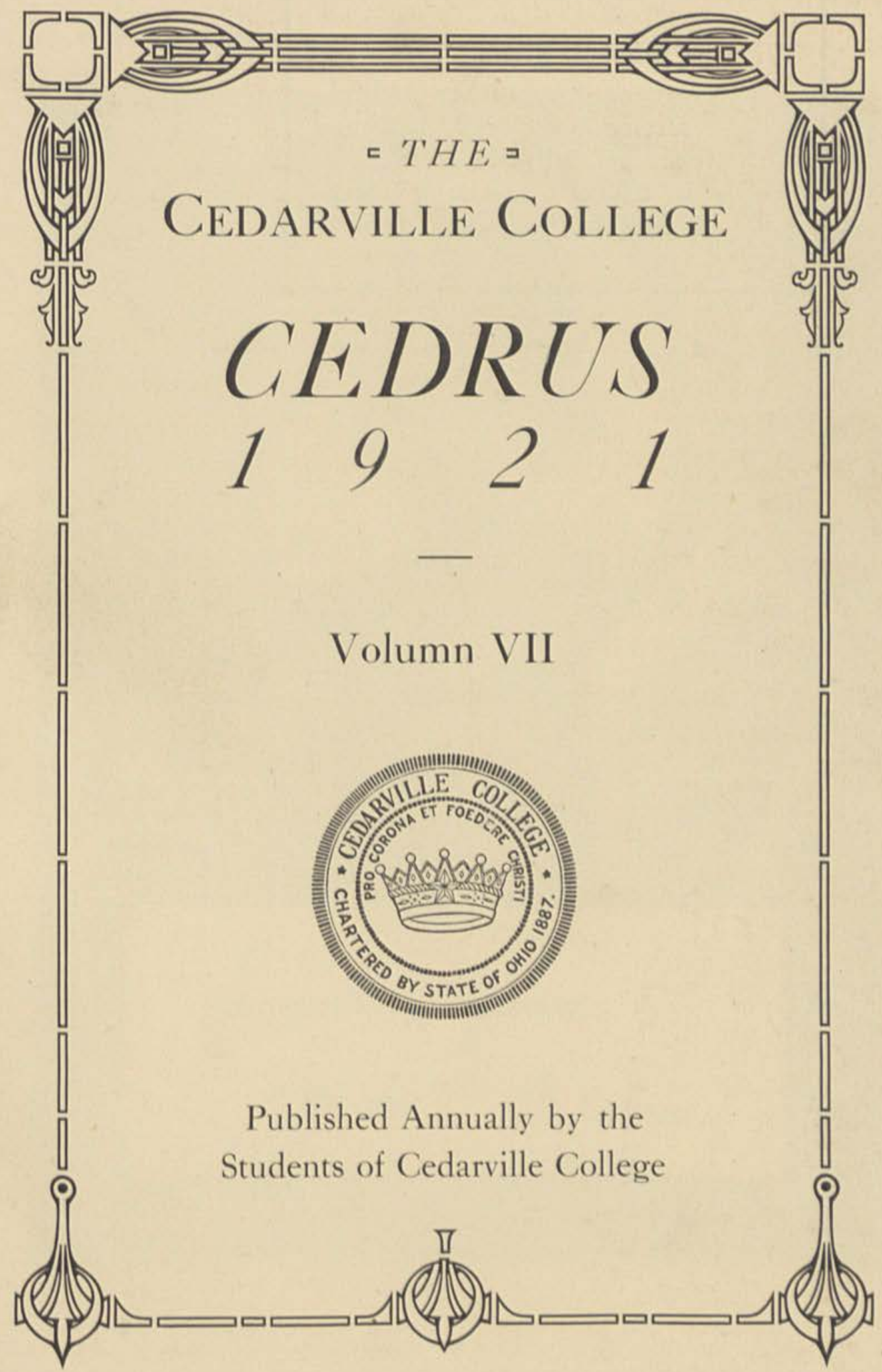




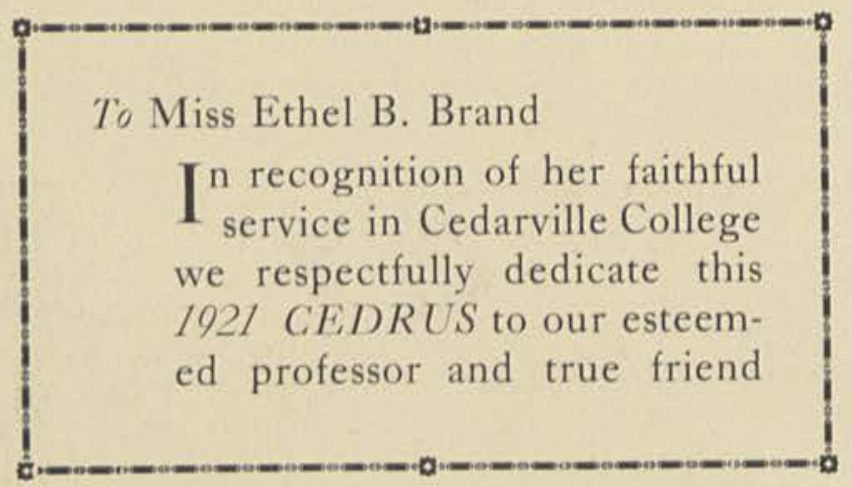




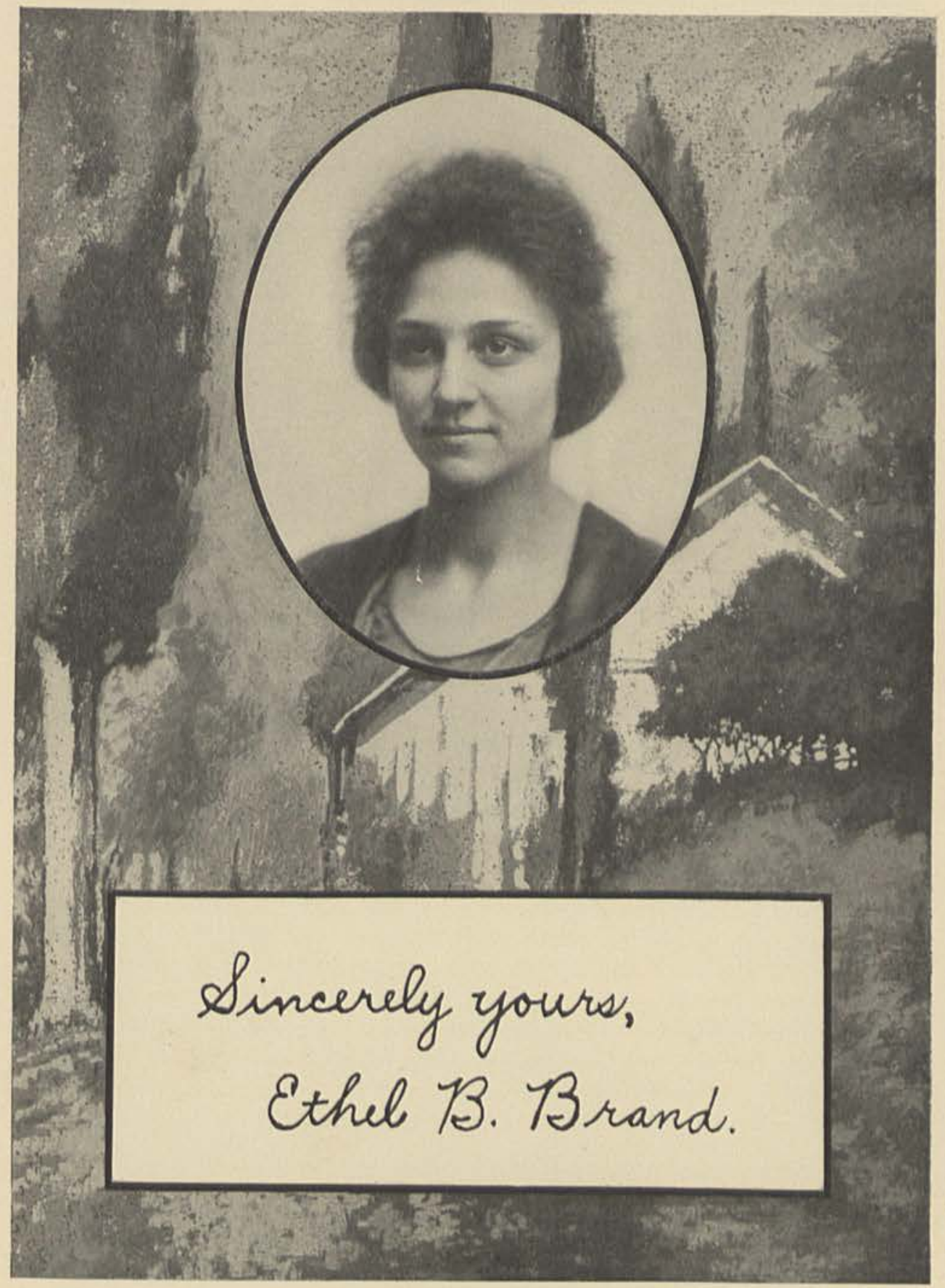




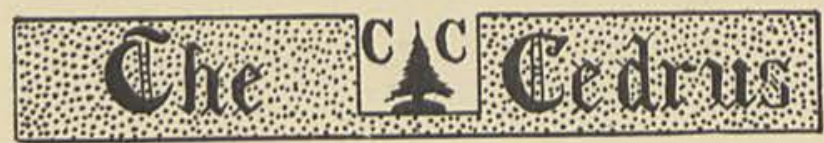

\title{
Foreword
}

\author{
5. \\ "Lest you forget the dear old ways, \\ The joys, the toils of youthful days, \\ This book of memoirs to you we give \\ That College years may always live."
}

Unwritten history must necessarily be quickly forgotten, hence this volume.

In presenting this reflection of College life we decline to make any apologies, although the work may warrant such. Yet we feel that we have striven in the highest degree to produce a memoir that we hope shall meet with your approval now and may serve in the future to recall "Those good old days" at C. C.

If you who possess this volume shall reap from its pages one-half as much enjoyment as the staff has harvested in work and worry, we know our efforts shall be well repaid.

We desire to thank the faculty and students of our College for the splendid cooperation which was afforded the staff, and especially do we feel grateful to our advertisers, who have so well supported this volume.-Editor. 


\section{1}
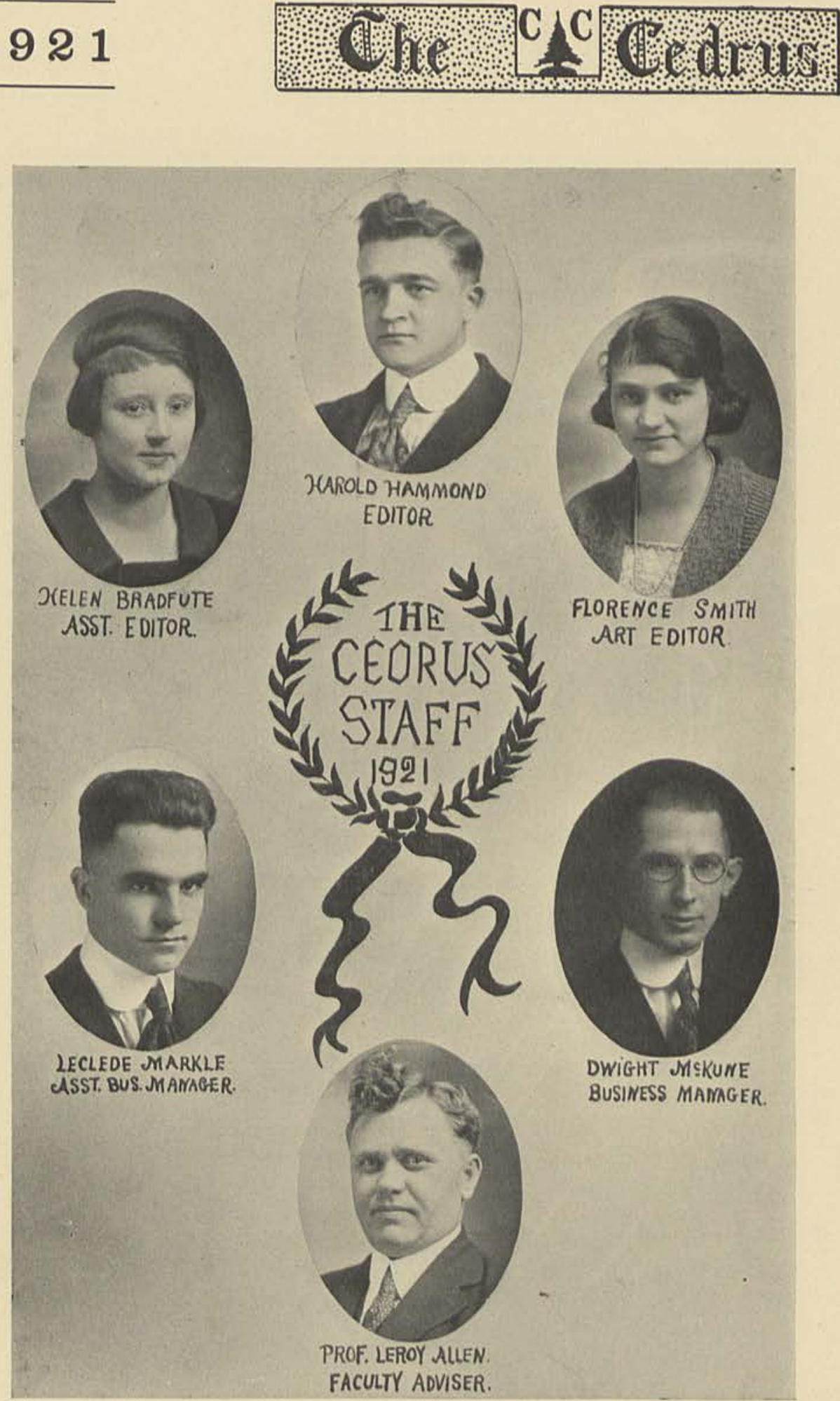

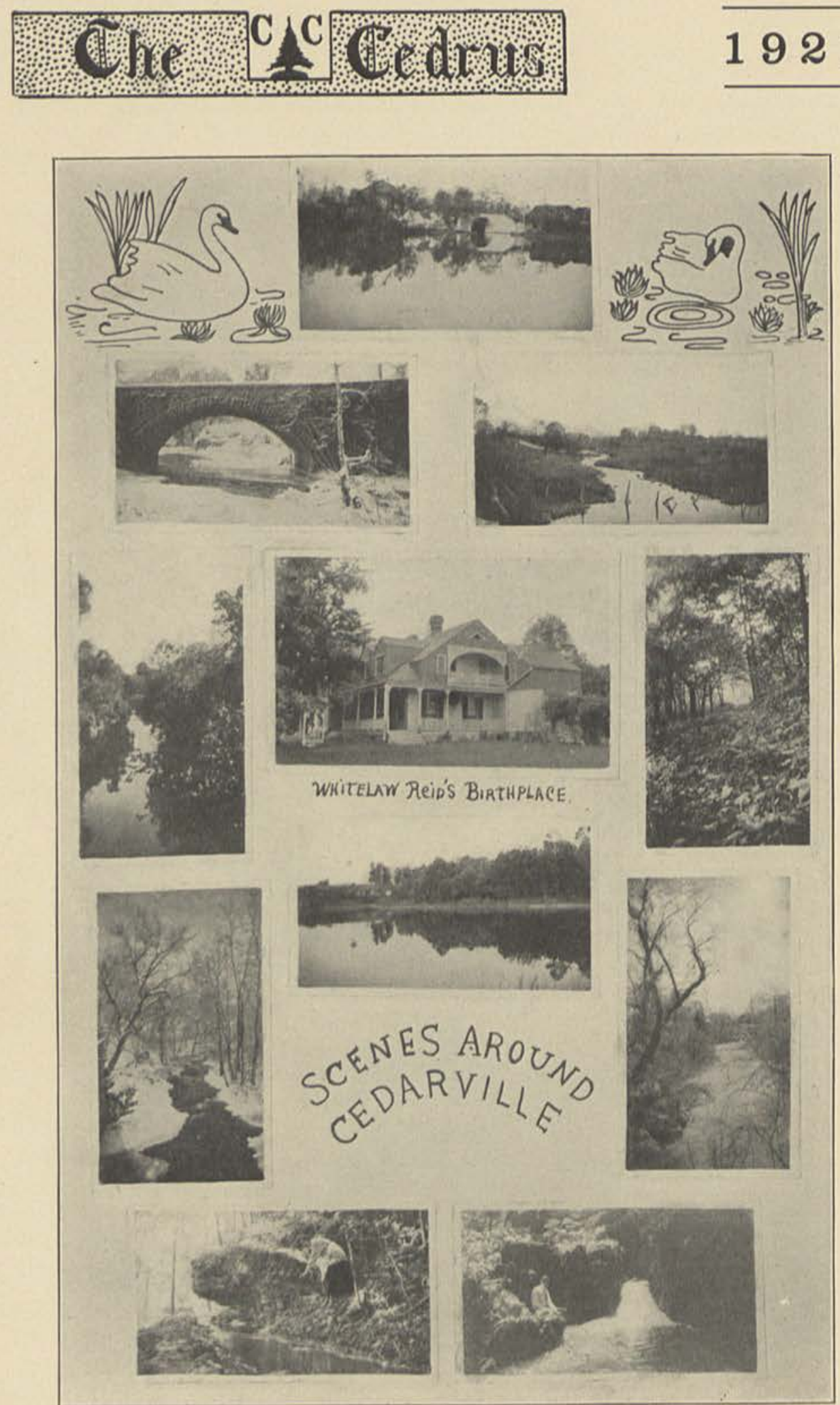


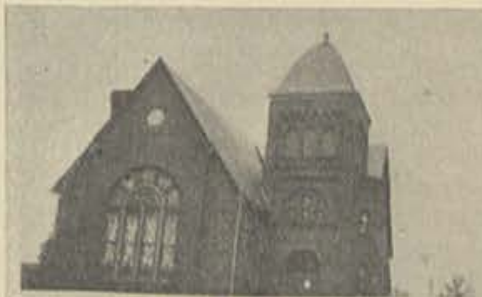

UR.R СHURCH

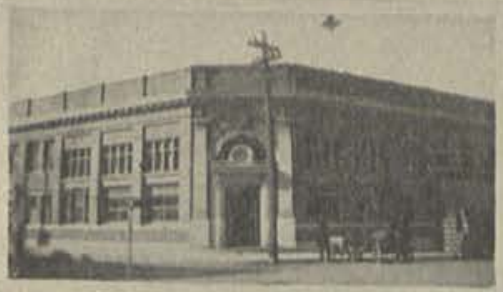

OUR NeW BAMK.

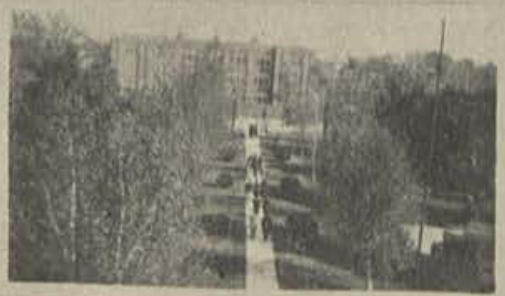

AEROSS THE WAY -

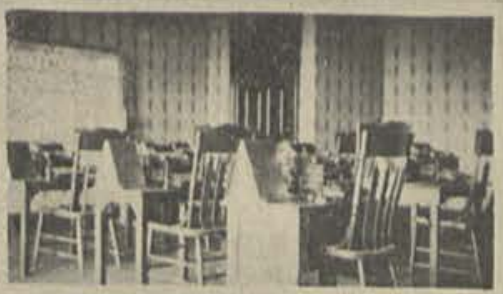

TJPEWRITING DEPT

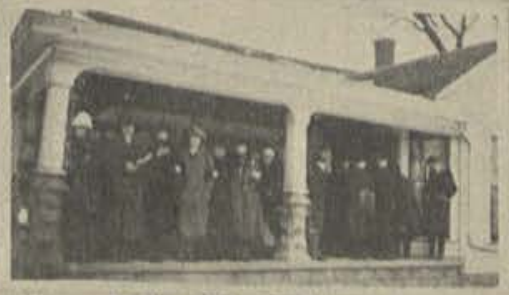

TAE QLUB "

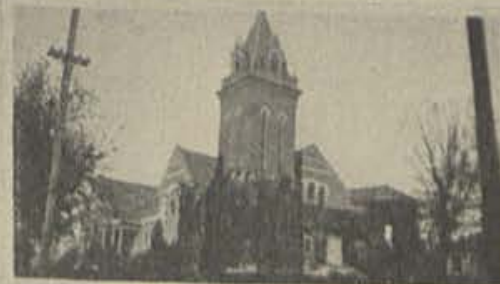

R.P. CHUREH.

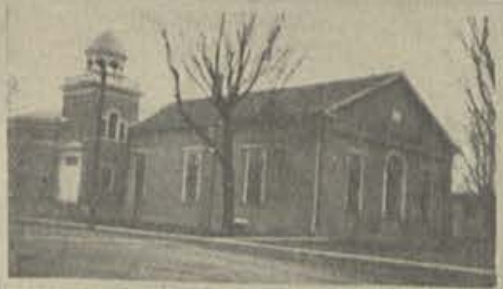

CM.E. CHUREH.

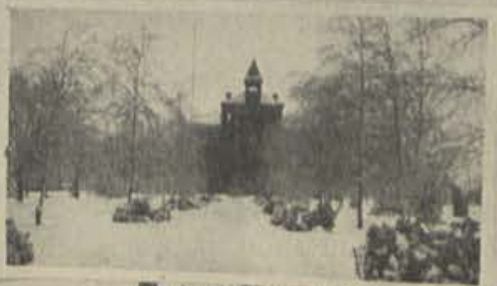

SNOWBOUND -

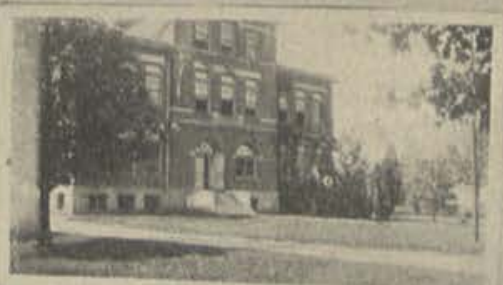

COLLEQE.

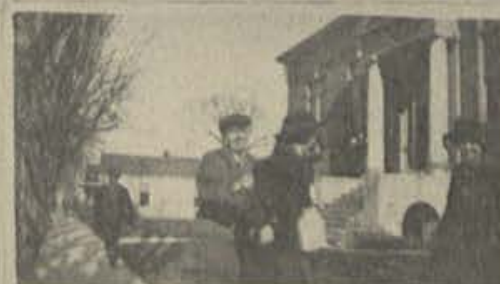

CARNECIE LIBRARY 


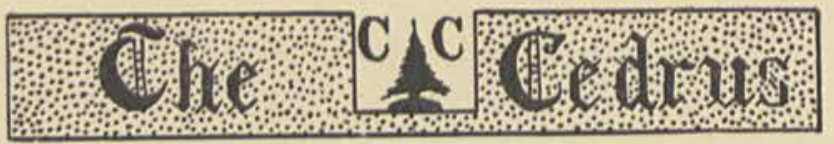

\section{1}

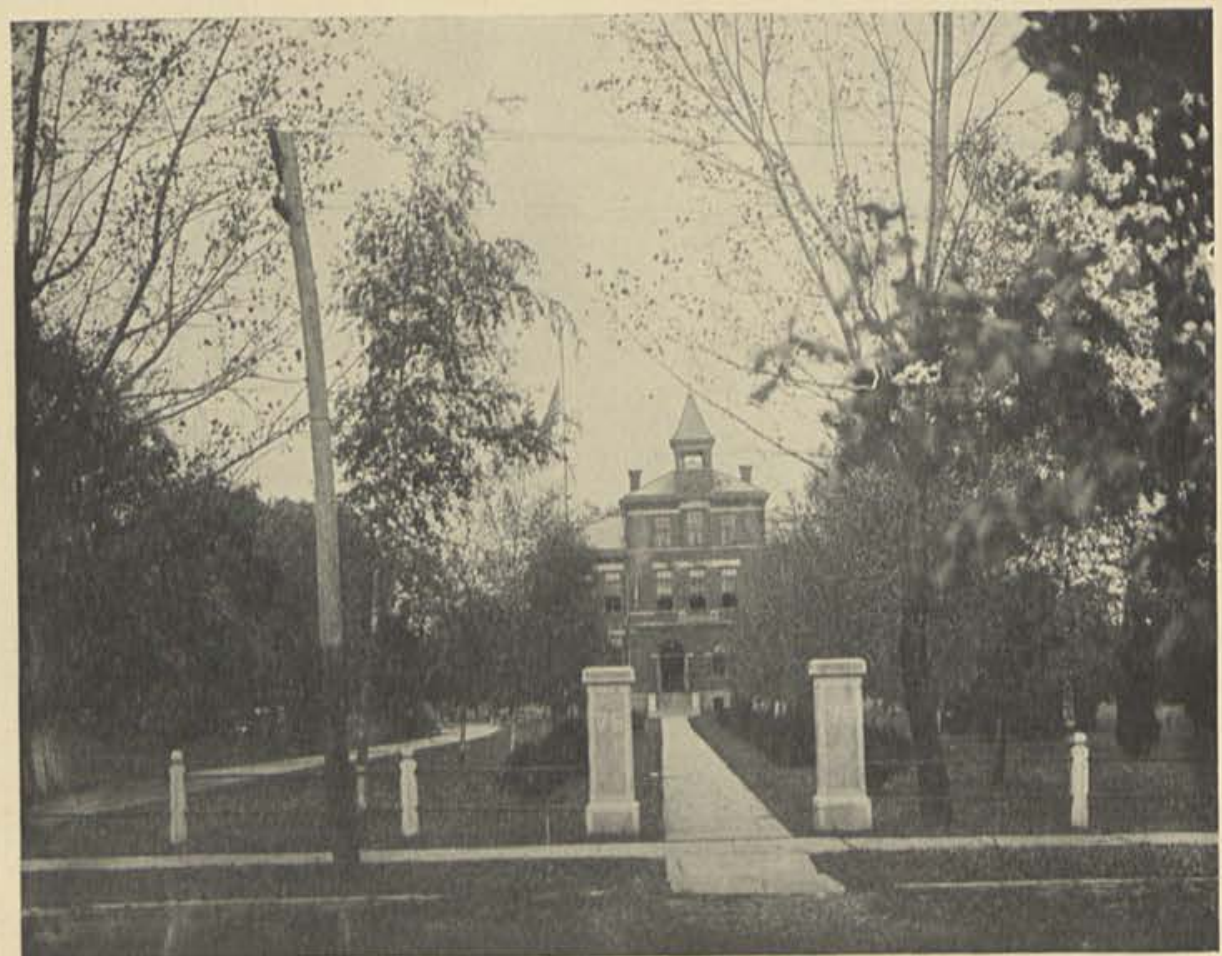

CEDARVILLE COLLEGE

YESTERDAY

\begin{tabular}{|l|}
\hline \\
स्ज?
\end{tabular}

ESTERDAY, twenty-seven years ago, Cedarville College was but a dream. September 19, 1894, the fulfilment of the dream began. A rented house for quarters, a faculty of five, thirty-six students, a plot of ground, a nest-egg of $\$ 20,000$ for endowment, and a literary society - the Philadelphian - with these the dream began to be realized. The next year brought the present College Hall, the planting of the campus, sixty students, football, tennis, baseball and another literary society-the Philosophic. In 1902 came the Alford Gymnasium. In 1905 Andrew Carnegie's gift was received and the new Carnegie Library was entered in 1908. The Y. M. C. A. was organized in 1907, and the Y. W. C. A. in 1909. The Theological Seminary was added in 1913 . In 1915, the first president, Rev. David McKinney, D. D., LL. D., after twenty-one years of faithful, pioneer service, resigned. He was succeeded 
by the Rev. W. R. McChesney, Ph. D., D. D. The endowment fund had grown to the sum of $\$ 83,000$ and Cedarville College was well established to enter upon a most useful career.

\section{TODAY}

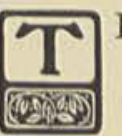

HE endowment now amounts to $\$ 117,000$ for the College and $\$ 75,000$ for the Theological Seminary. During the past year the College came into the possession of one hundred acres of land bequeathed by the late Anderson Collins to be known as the "Collins Educational Fund for the Training of Young Men and Young Women." The faculty now numbers fourteen. There are five departments of instruction. The attendance in all departments is one hundred and eighty-seven. The Orange and Blue Literary Society, founded in 1917 , has taken the place of the original societies, and it is rendering an invaluable service. The Alumni Association is thoroughly organized and is cooperating in every possible way with the College authorities. The Board of Trustees and the Ladies' Advisory Board are doing efficient work. The present faculty is composed of College and University trained men and women, who are working to their limit for the progress of the College. The Community and the Church are back of the College as never before in its history. The cooperation between the College and the High School is commendable. The Basket Ball season has been a good one. The spirit for all athletics is high.

\section{TOMORROW}

OMORROW is to be bigger, brighter and better. The College is in The Greater Athletic League of Cedarville. The plans are laid for a physical director and coach for football, basketball and base-

ball. Next year will witness a new era in Athletics and physical culture. The Alumni Association has organized and is forming plans to raise $\$ 100,000$ for the endowment fund and thus make their Alma Mater a full fledged member of the Association of Colleges of Ohio. The College now is recognized by Ohio State University and the Department of Public Instruction in the State of Ohio. The Community is expected, along with the church and other friends to raise $\$ 100,000$ to remodel and refit the present Gymnasium for a Science Hall, erect a new Gymnasium, and a new Science Hall. A large increase of students is expected next Fall. The largest attendance in the history of the College will be enjoyed. The highday of Cedarville College is on. Come and cooperate with us to make Cedarville College all that it ought to be just as soon as it is possible for us so to do.

W. R. M. 


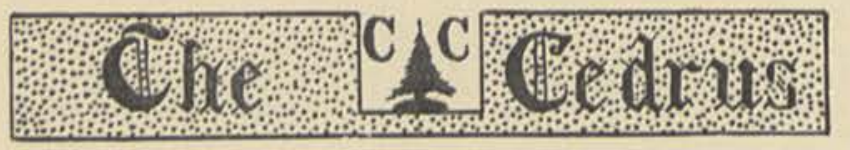

\section{1}

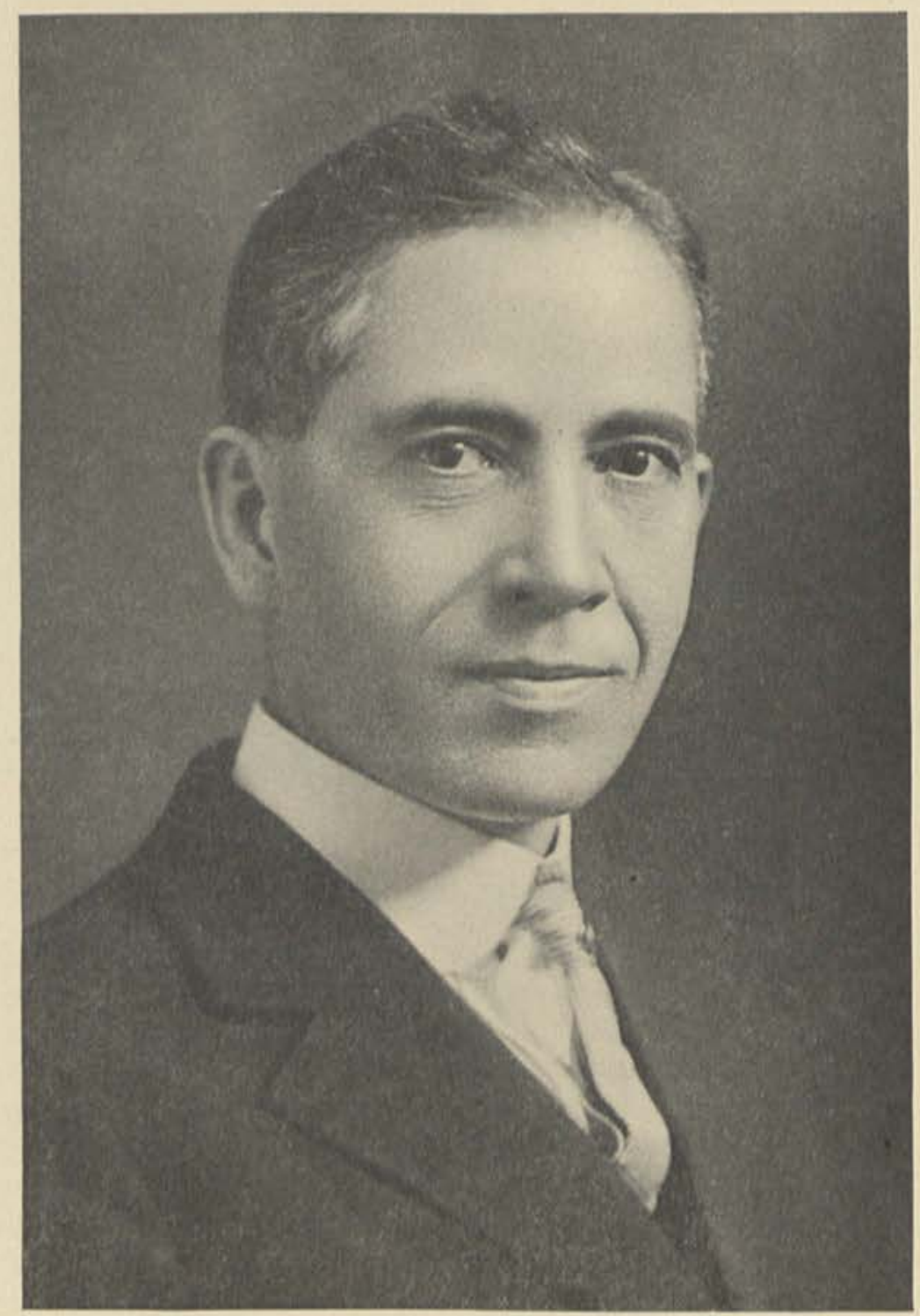

W. Renwick McChesney, PH. D., D. D. PRESIDENT

Professor of Psychology, Oratory, Greek 


\section{DR. MCCHESNEY AS A TEACHER}

\section{FROM A STUDENT'S VIEWPOINT}

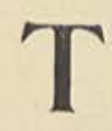

HE history of Dr. McChesney as a teacher is practically the history of Cedarville College.

Dr. McChesney has done very little teaching outside of Cedarville College. His first experience at teaching was at Franklin College. There he was Professor of Latin and Greek from 1890 to 1894 . In 1894 he came to Cedarville College as Instructor in Greek. Since then he has risen to the Presidency of Cedarville College and to the position of Dean of the Reformed Presbyterian Seminary. Woostcr College has claimed our "prexy" for seveial summers, teaching Latin and Psychology. His life has therefore been that of the College. It has been through his efforts that the college has prospered and he has great plans and aspirations for the future.

Cedarville College has not been the only school to seek the services of our distinguished orator and psychologist. He has received many offers to leave our institution and give instruction in other schools; such schools as Parsons College, Iowa; Baldwin University, Kansas; and Wooster College, Ohio.

In the classroom we find him a perfect logician, presenting in a pleasant and yet persuasive manner the problems and facts of the subjects he teaches. No subject is too dsep but what he can find in it some thought, some use or principle which can be adequately presented to his students. A student can enter his classes with but a vague conception of the truth of his lesson, yet before he leaves the room he knows that truth and can explain it in all its many details. One of his favorite methods of teaching is to illustrate a subject. His illustrations are to the point and very often drive home a moral axiom or rule to aid in the student's Christian life. He never lets an opportunity pass in class, or out of class, to build up the faith of all in the principles of Jesus Christ. Outside of class he is noted for his being a friend to all, assisting and helping, scholastically and otherwise. From his keen, well trained psychological, yet ethical and practical mind, the student receives much help and advice. Dr. McChesney loves his work and his students, and he receives his best wage in that they love and appreciate his worth.

N. H. T. 


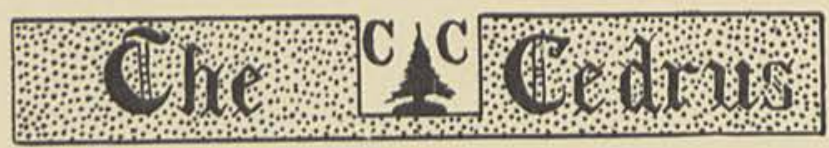

\section{1}

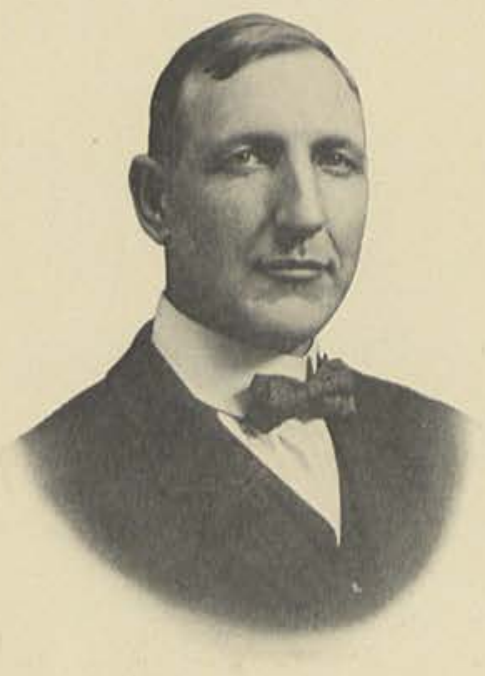

Rev. Frank Albert Jurkat

Treasurer

Professor of Modern Languages Hebrew and History

A. B., Franklin College 1895

A. M., Franklin College 1898

LL. D., Franklin College 1917

Rev. Leroy Allen

Dean and Registrar

Harper Professor of Economics and Sociology

Ph. B., Wooster University 1906

Xenia Seminary 1914

A. M., University of Chicago 1920
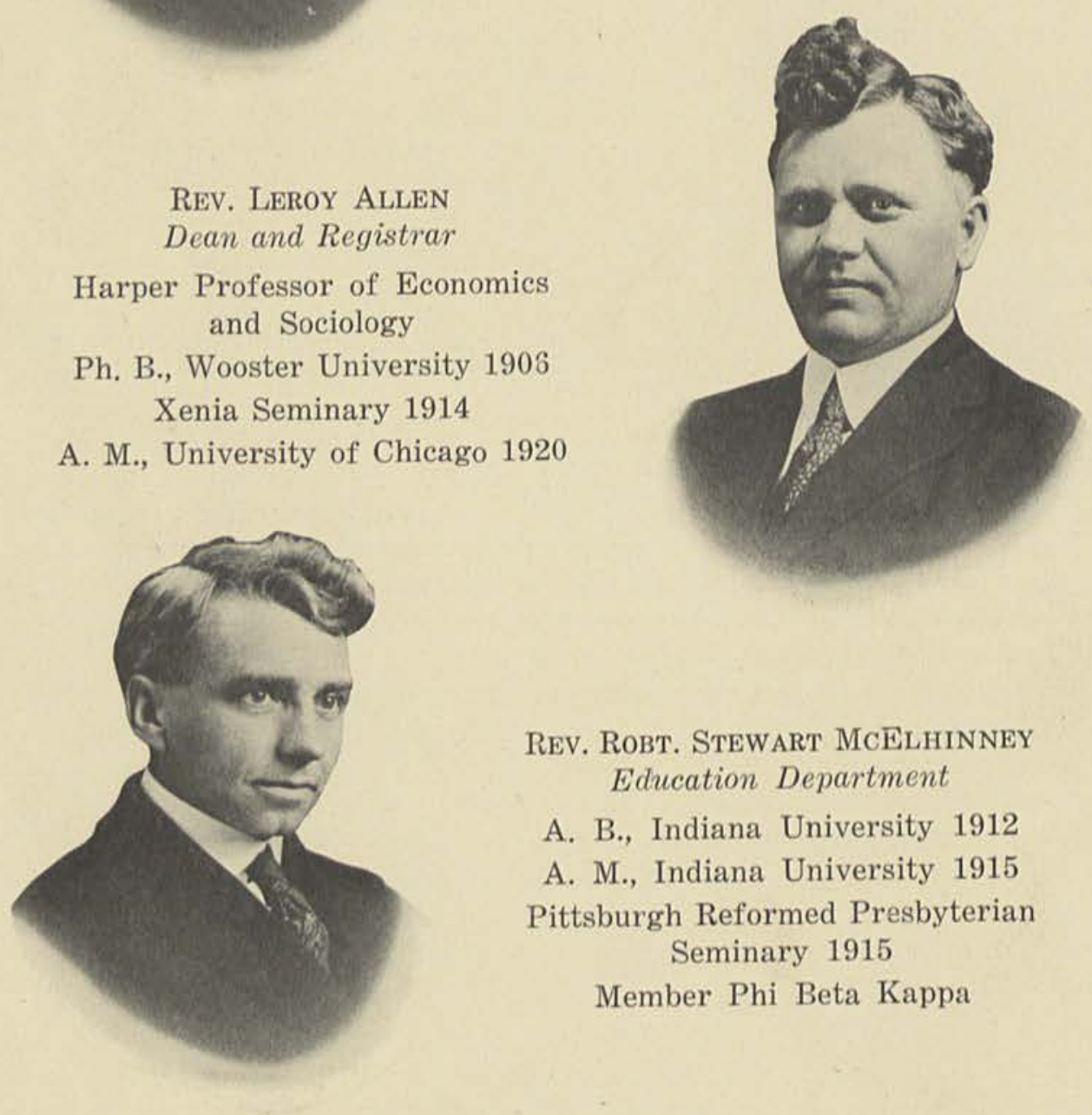

Rev. Robt. Stewart McEllinNey

Education Department

A. B., Indiana University 1912

A. M., Indiana University 1915

Pittsburgh Reformed Presbyterian

Seminary 1915

Member Phi Beta Kappa 


\section{1}
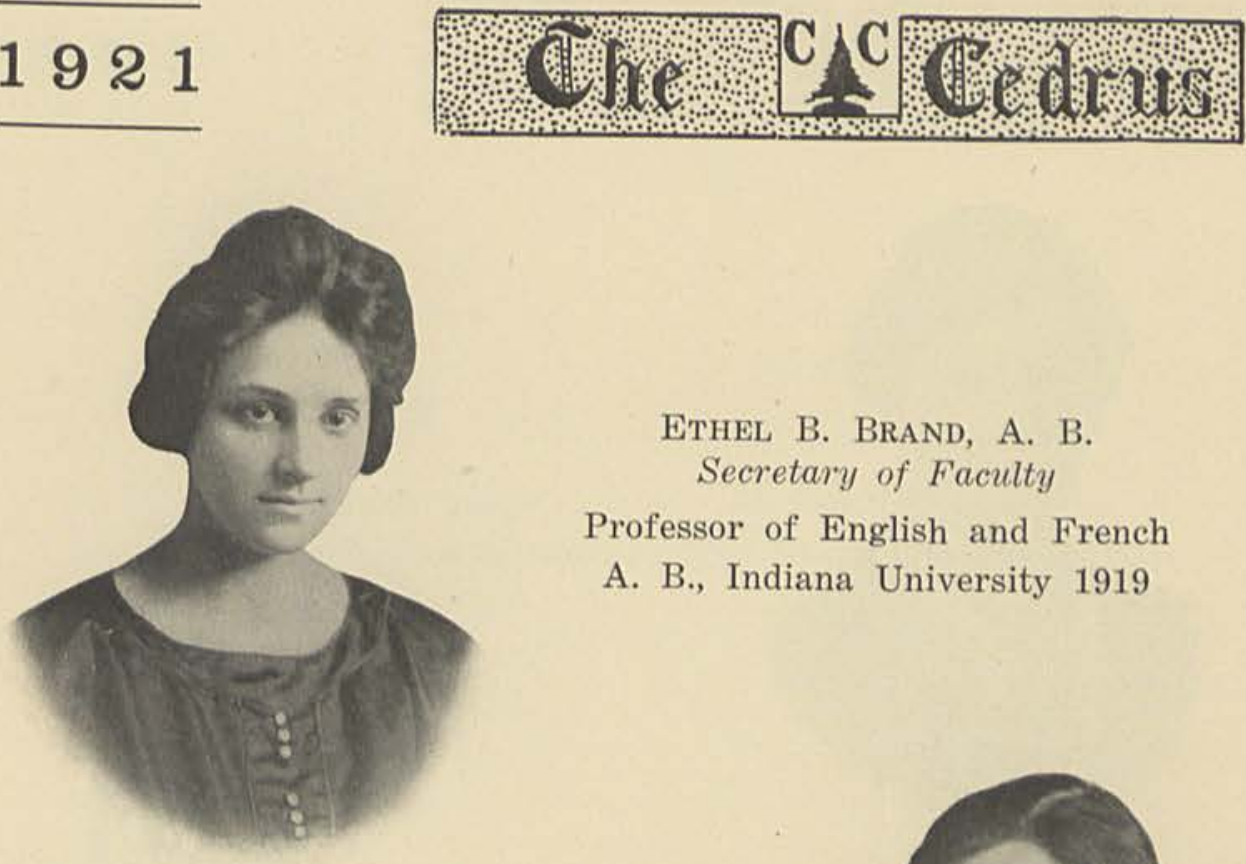

Ethel B. BRAND, A. B.

Secretary of Faculty

Professor of English and French

A. B., Indiana University 1919

Milicent L. Hathaway, A. B.

Professor of Mathematics and Natural Sciences

A. B., Wells College 1920
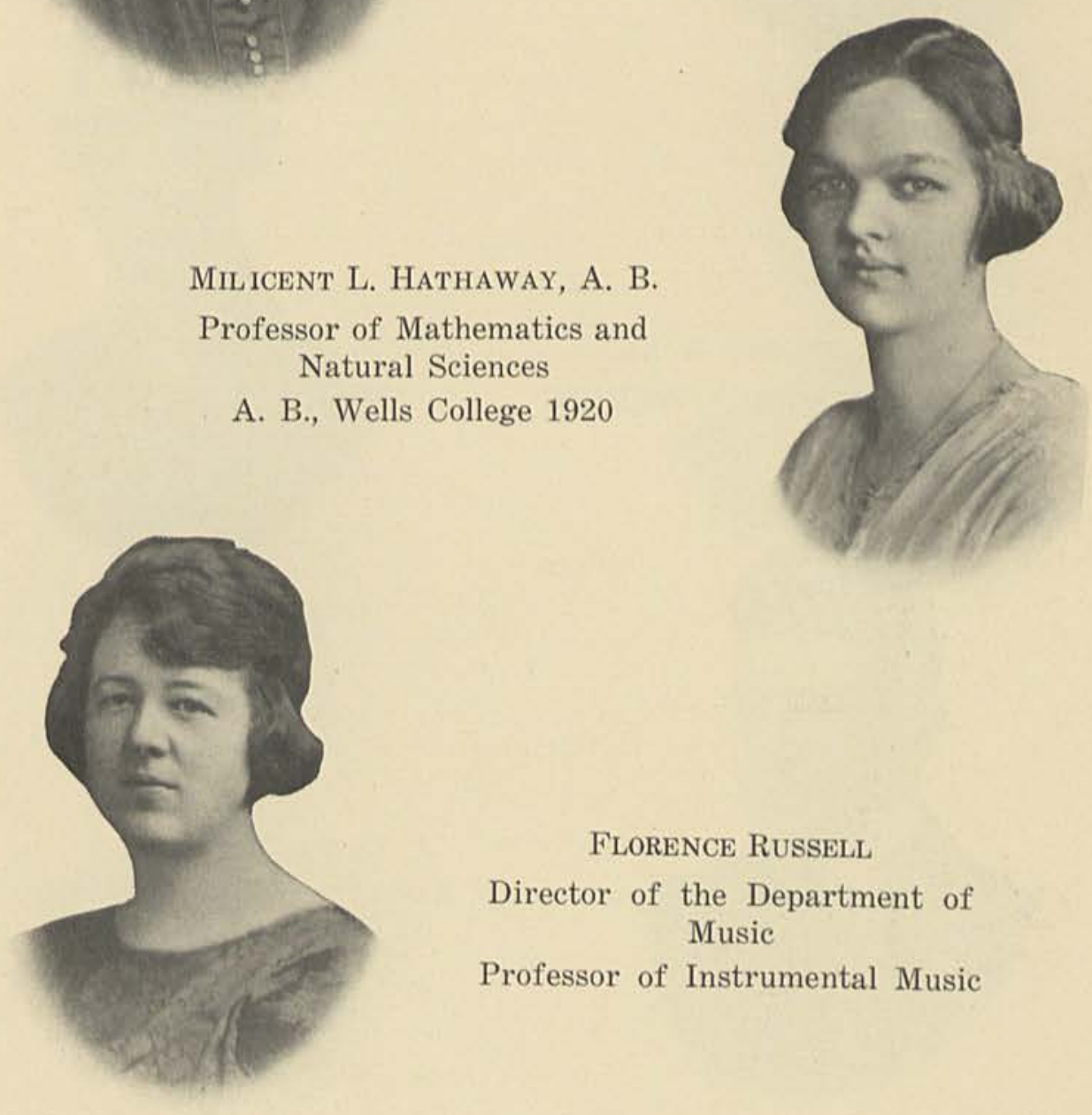

Florence Russell

Director of the Department of Music

Professor of Instrumental Music 

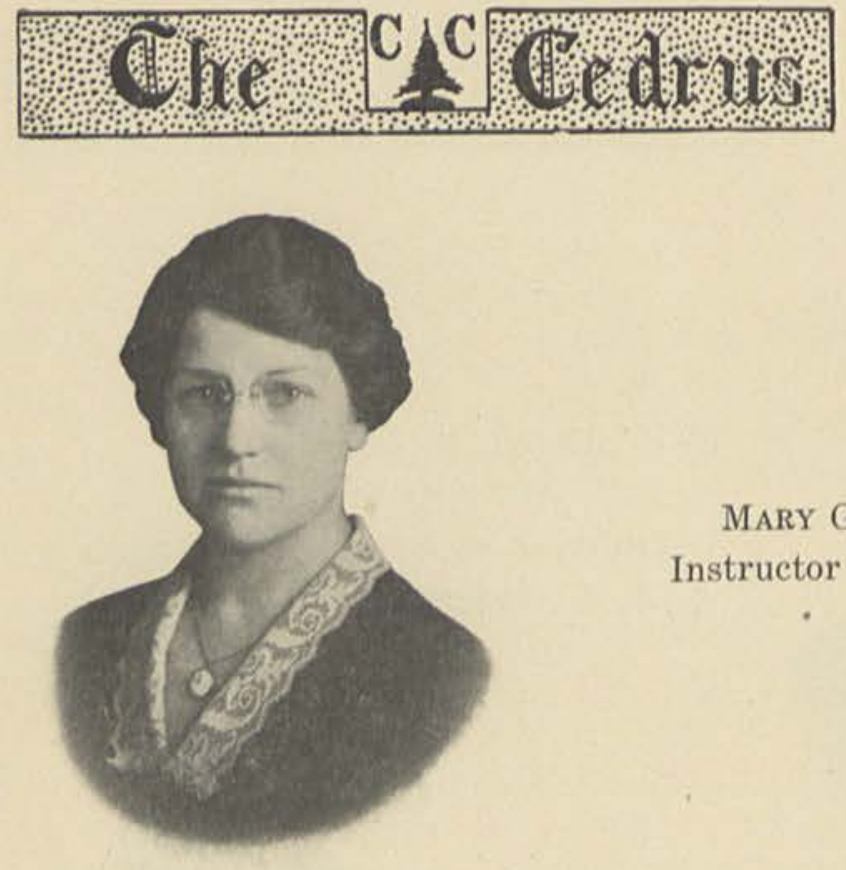

MARY GOODE ROYAL

Instructor in Vocal Music

E. Dwight McKune

Instructor in Typewriting
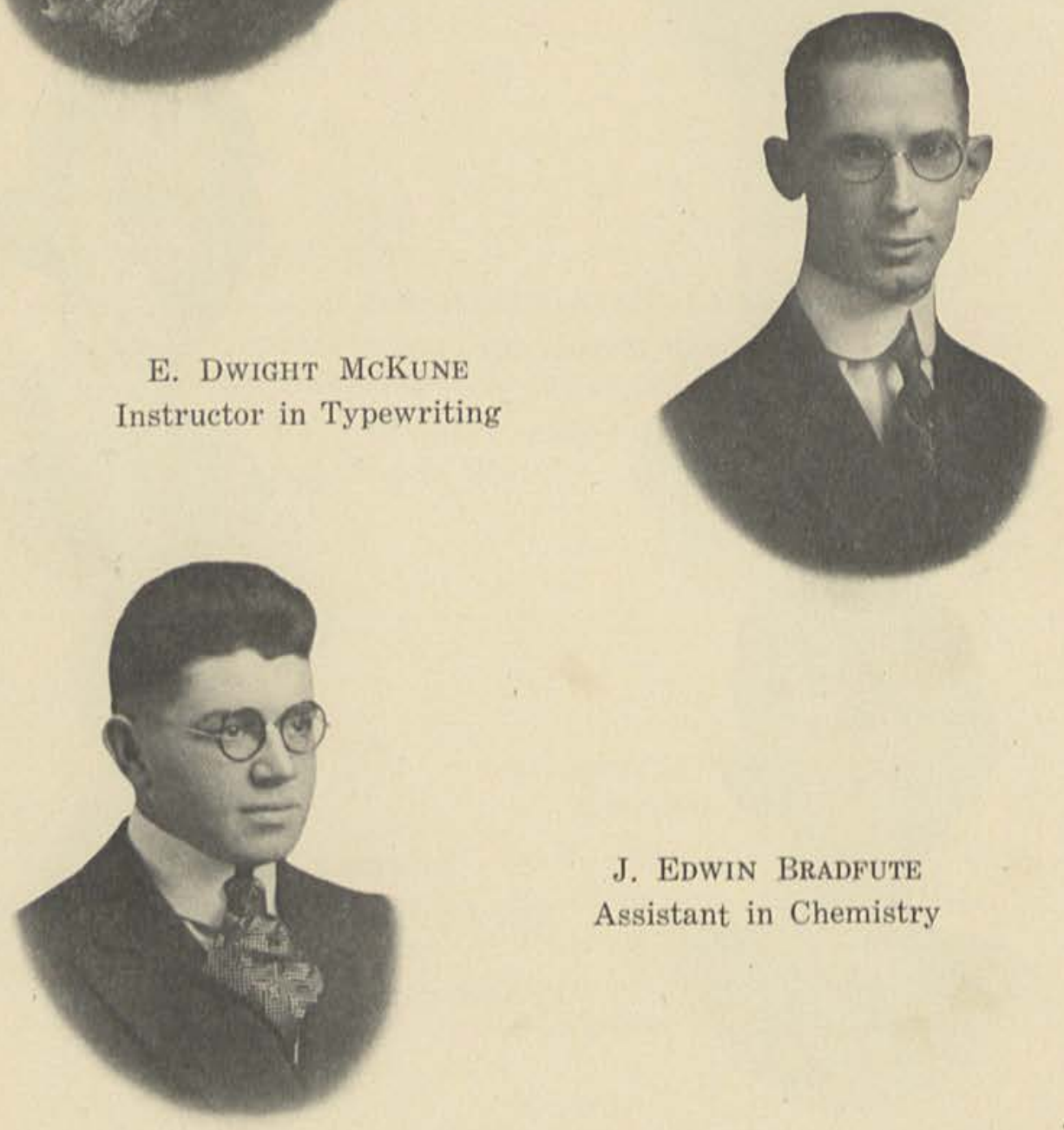

J. EdWIN BRAdFute

Assistant in Chemistry 


\section{1}
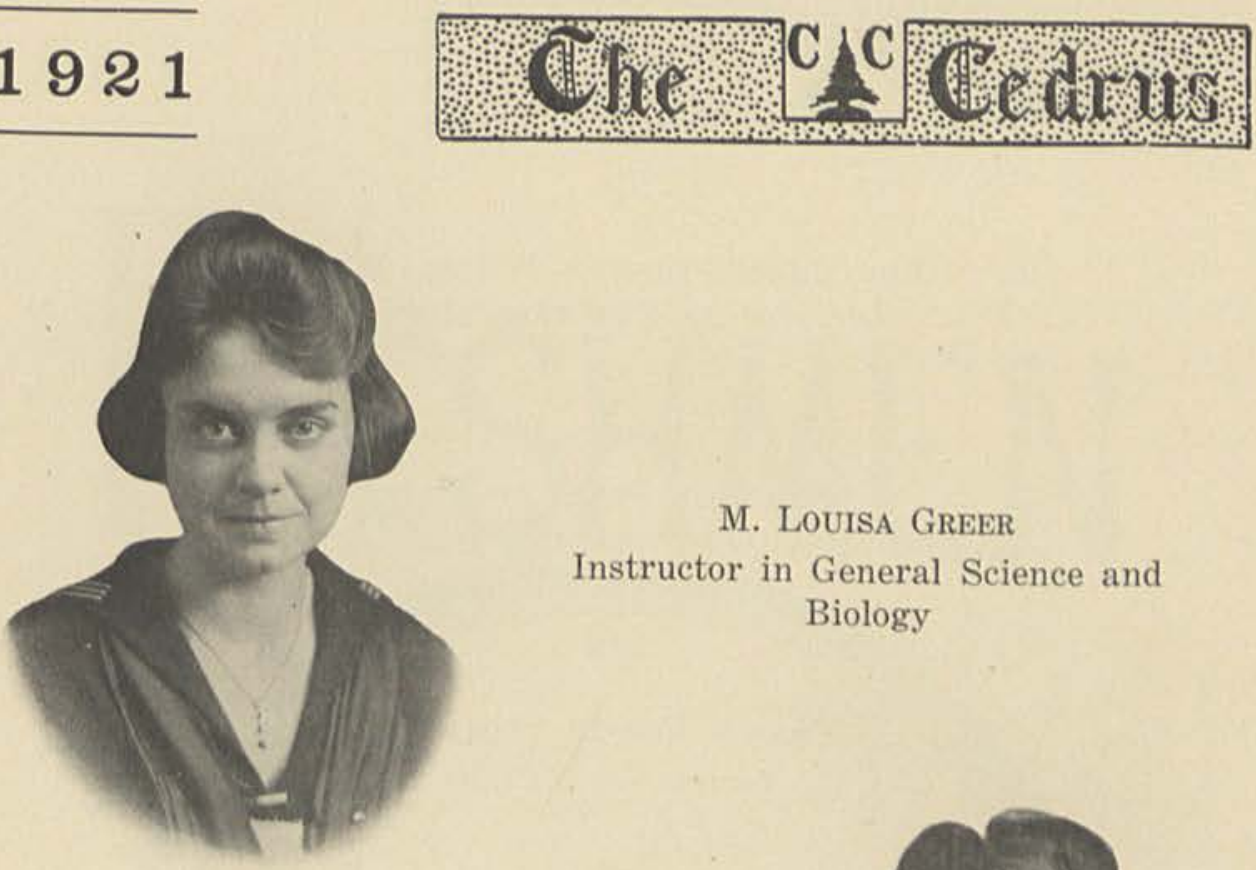

M. LOUISA GREER

Instructor in General Science and Biology

JOSEPHINE RANDALL

Instructor in Algebra and Geometry
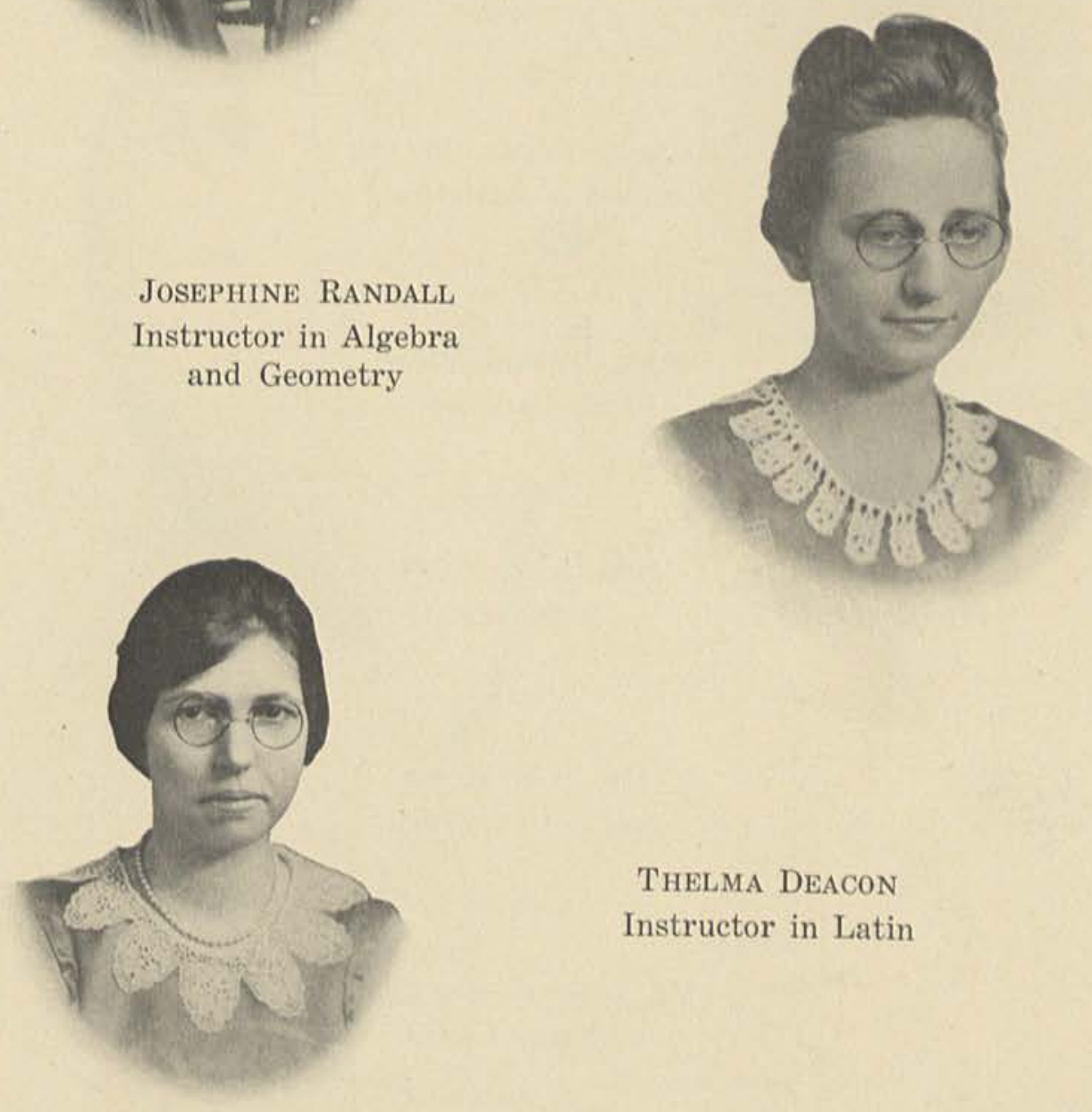

Thelma Deacon

Instructor in Latin 


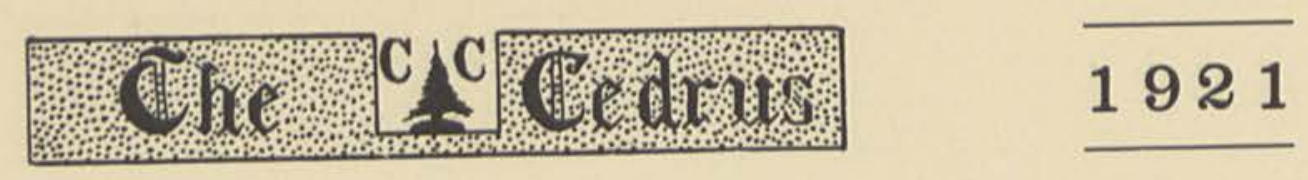

Rev. John Pressley White, M. D.

Lecturer on Christian Missions

เ5.

Mrs. John Pressley White

Lecturer on Christian Missions

2.5.

MARION FOSTER STORMONT

Instructor in Civics

is.

ANDREW ROGER COLLINS

Coach of Athletics

¿.

Mrs. Clara Morton

Club Cateress

15.

Mrs. A. E. HuEY

Librarian

+5.

MR. A. E. HUEY

Janitor of Library

S.

Mr. JoHn C. GRINDLE

Janitor of College 


\section{1}
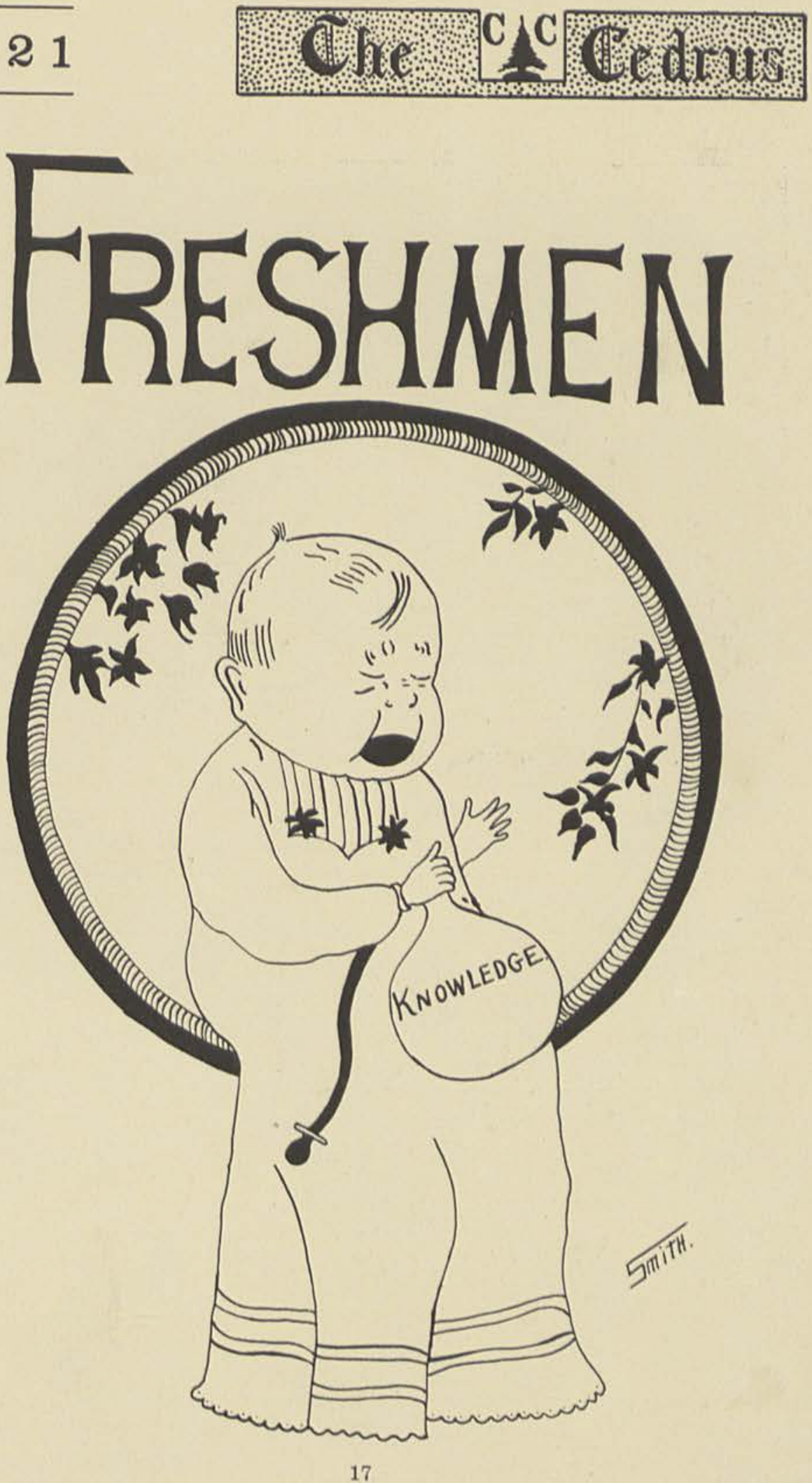


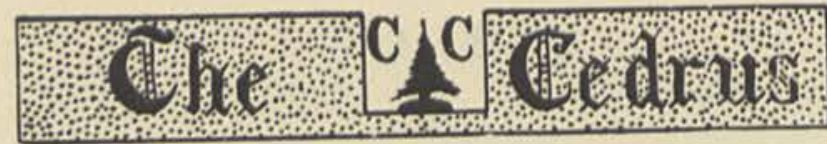

1921

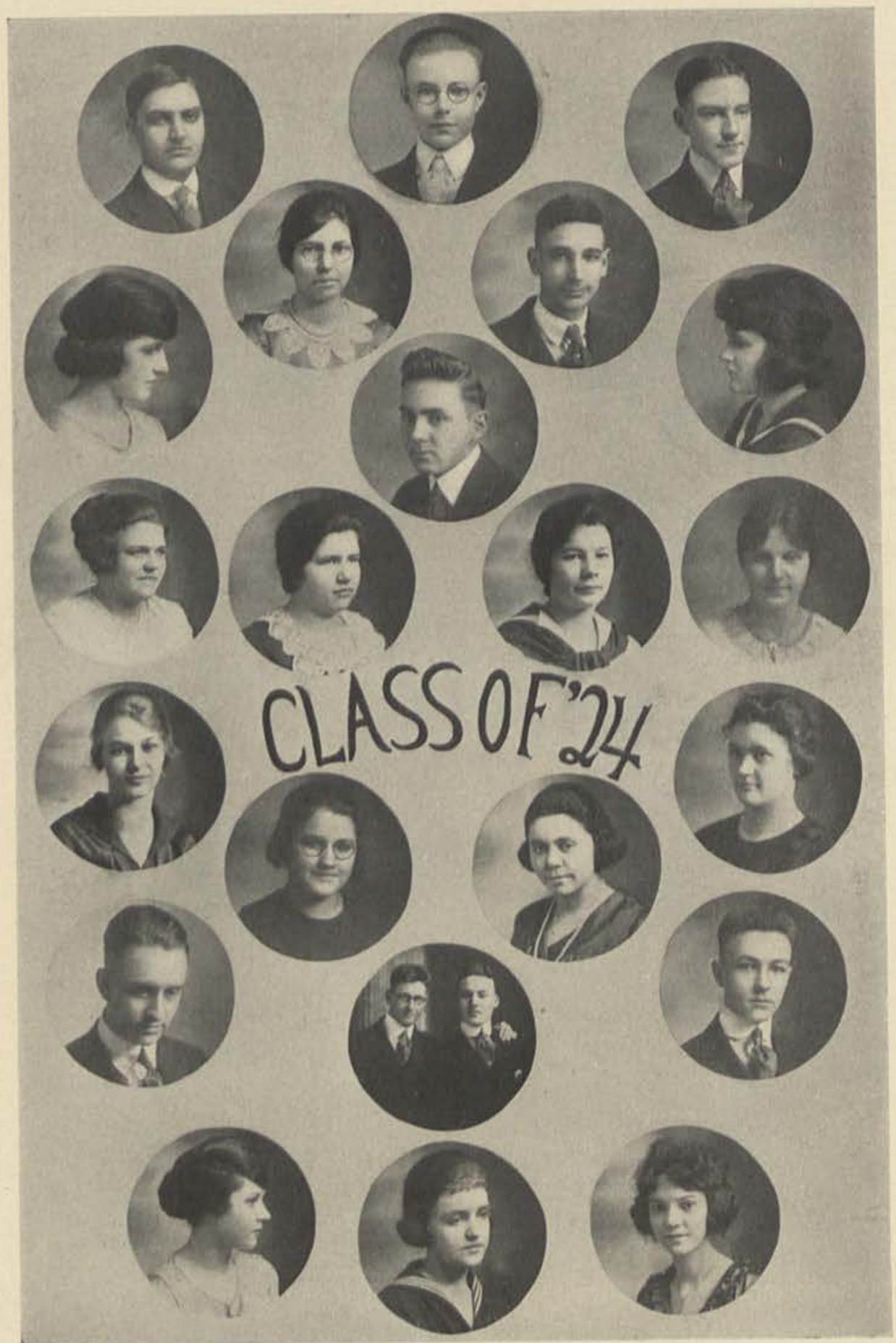




\title{
1921
}

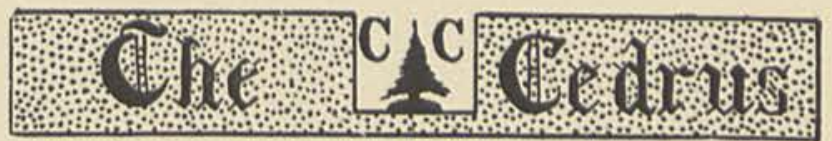

\section{OFFICERS}

\begin{abstract}
President__._._. Colman
Secretary _._._._. ALICE MCKIBBEN

Treasurer.

LUCILE JOHNSON

Historians. ANNA HARPER, LUCINDA CASKEy

Poets ALICE MCKibBen, LuCILE JoHnson
\end{abstract}

Class Flower: Lily of the Valley

Class Colors: Purple and Gold

\section{THE HISTORY OF THE FRESHMAN CLASS 1920-21}

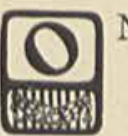

$\mathrm{N}$ the morning of September 16,1920, twenty-three happy boys and girls started in their Freshman year in Cedarville College. It was a splendid autumnal day and the air was permeated with the spirit of school days. With a feeling, somewhat of awe, we wended our way to the College to register and file our lists of studies, after which we were directed to our rooms.

In the first meeting of the Freshman class the following officers were elected: Head Boss, George A. Colman; Recorder, Alice McKibben; and Dunner, Lucile Johnson.

For the first few weeks the Freshman class had the name of being "slow" because we had no spreads. At last the grand and glorious night came when the Freshmen had their first "spread" without even the interference of the upper-classmen.

As Freshmen of high rank, we are a source of comfort to our "Profs" and it is not strange to find some of our members at the head of the few Cosmopolitan classes. Besides this we excel in other branches of our college life. Religiously we cannot be beaten for we have two Elders and one Deacon.

Our programs are enhanced by the exquisite singing of Lucile Johnson, accompanied by the Harp-(er), the wit of the Elders and the quaint remarks of Calla and Edna, who come from a Glen in Kentucky. Space does not permit us to write the praises of our entire class and therefore the Hart of the whole matter is, we are some "Class" representing the following territory, Canada, Pennsylvania, Ohio, New York, Florida and Kentucky.

At the end of the first semester we lost one member, Gertrude Insley, and gained four, making twenty-six in all.

L. C.-A. H. 


\section{THE FRESHMEN UP-TO-DATE}

Many classes have come to school,

And some have found renown,

But in this class there wasn't a fool,

Not one could there be found.

There was Dick Elder, the wittiest boy

That ever hit our town.

He came from Pennylvania State,

And made life one glad round.

And Curtis, he's a gallant son,

From Pennsylvania, too,

He loves that little "Valley" Miss

With eyes of clearest blue.

Gavin is our preacher boy

He loves to go to Kyles;

With dear Christine for two years now

His time away he whiles.

George Colman is a home-sick lad,

He longs for New York State;

His countenance is sometimes sad,

He must think that girl's "great."

Gertrude likes a country lad

Who drives up in a Ford,

His face is always merry and glad,

$\mathrm{H}$ is name is much adored.

Rose Township sent two pretty girls,

A quiet happy pair;

One has brown eyes and dark brown curls,

The other golden hair.

When Findley struck our College halls,

The girls most all went mad;

Such beauty ne'er graced its walls

They think him quite a lad.

Calla and Edna are Kentucky belles,

But they neither fuss nor jest,

Lucinda and Olis in whom beauty dwells,

We're Eure they're Beaver High's best.

Glasgow lives where the Indians roved

Years now long gone by,

But the Serpent Mound still marks the spot

Upon a hill so high.

We have a "Deacon" in our Class,

And she's a wise one, too;

She is a tiny little lass,

But she's wise through and through.

Iva and Helen are wonderful pals;

Their studies require all their time,

In Basket Ball you may see these "gals";

They're almost in love with our clime.

These are the Freshmen of old C. C.,

The class of Twenty-four,

They all have the prospect, right honored to be

From them, we know you'll hear more.

M. A. M.

M. L. J. 


\section{1}
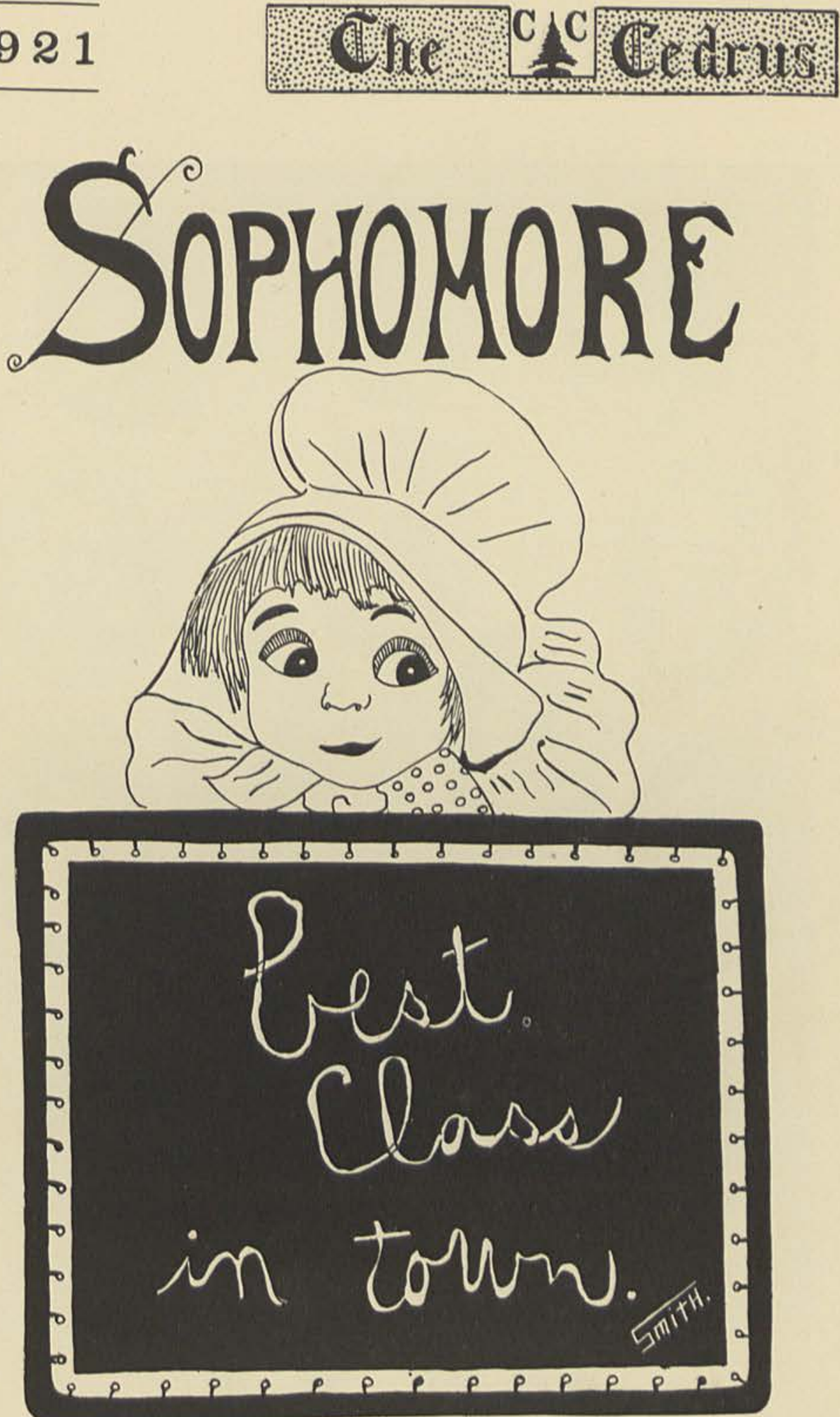


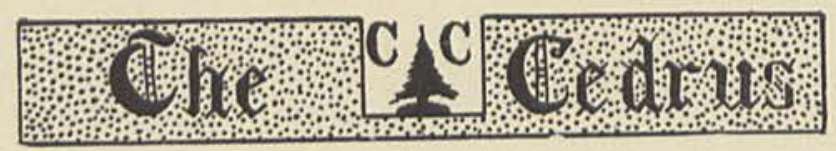

1921

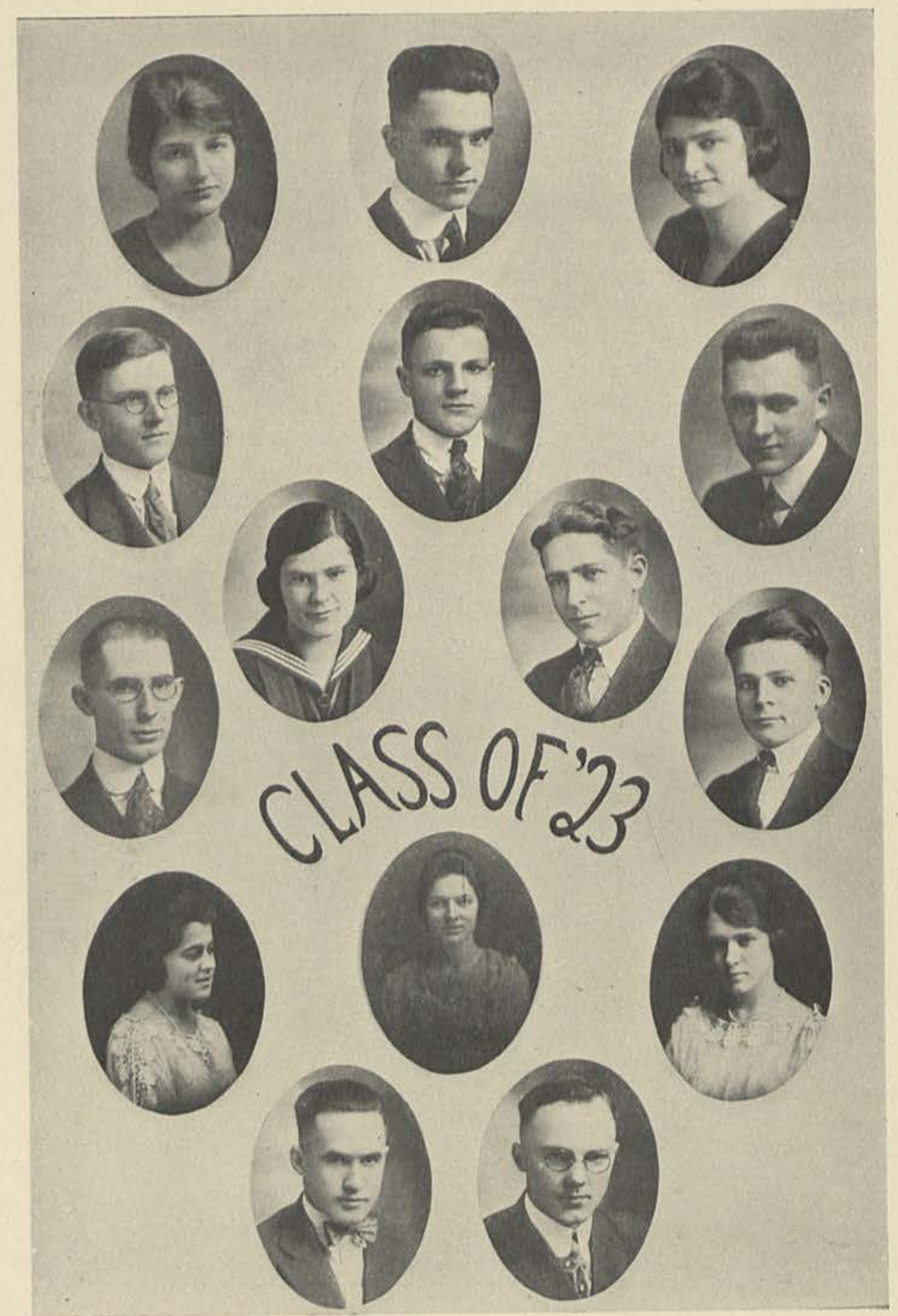




\section{1}
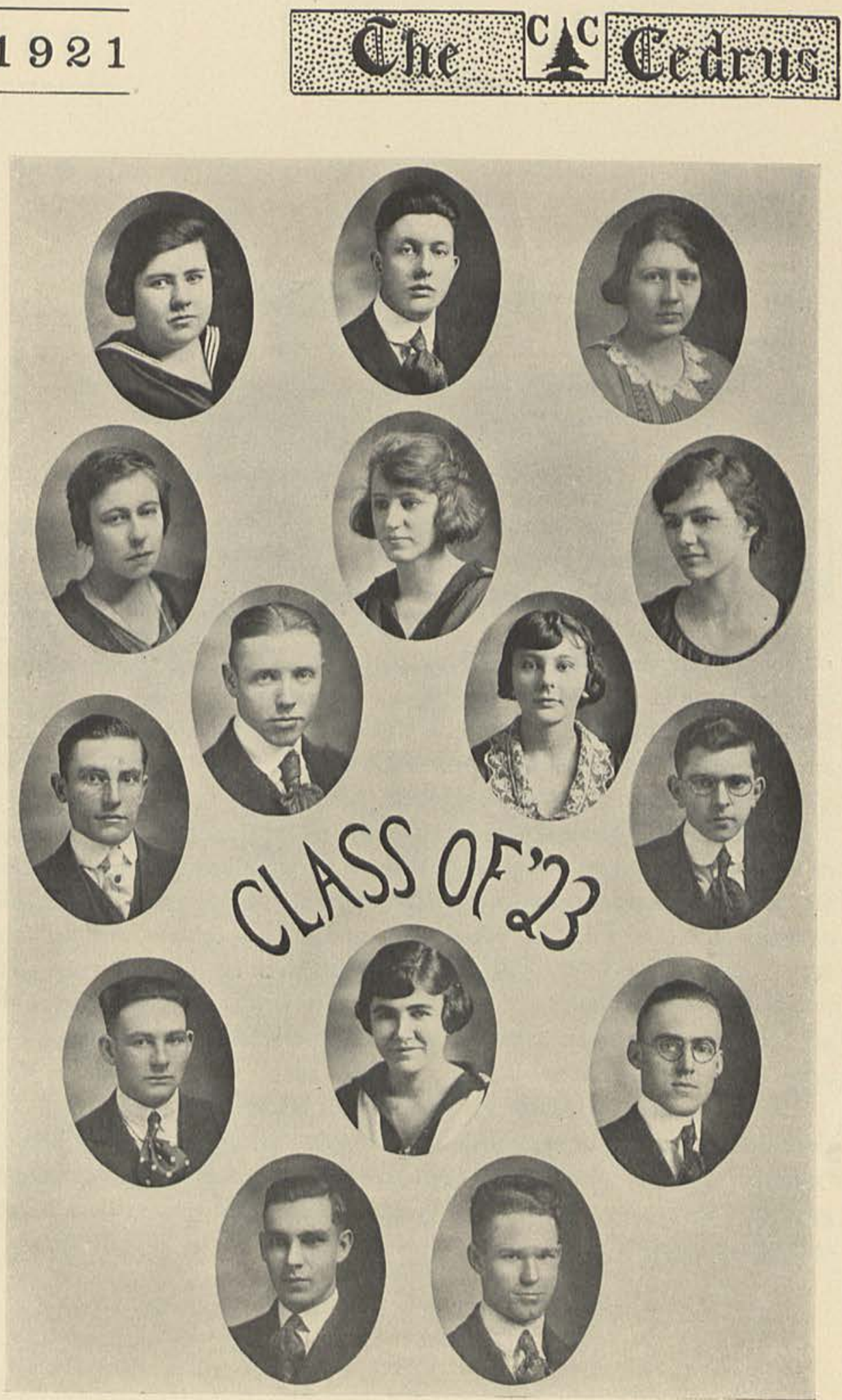


\title{
THE SOPHOMORES
}

\author{
President_..._. WILBUR W. White \\ Secretary and Treasurer..._._._._. MARJORIE WRIGHT \\ Class Colors: Gold and White \\ Class Flower: Buttercup
}

HE Sophomore Class still remains the largest in Cedarville College. Its members are always looked to by the rest of the college for the musical programs, for the star actors and actresses, for managing the basket ball games, and for the best yellers in school. Even the Faculty, wishing to have a very interesting meeting, call for some of our members. We can best show our might by the fact that the poor Freshies have been so scared they have never had one spread within five miles of town, and even at one of those they did not get their machines fixed until morning.

And tell me, please, where would our wonderful girls' basketball team, of which we are all so proud, be if not for our star basket shooter, "Flossie," our fast guards, "Cheese and Marj.," whom we are thinking seriously of using as tackles on the football team, and our tall centers, "Chris." and Ruth? Every one in the college is now especially interested in the campaign for better athletics for next year, and look who are chosen from the student body to represent them in this great work!- two sophomores. No other class in college can boast of a married couple, and of southern girls.

in spite of all our class rivalry we will always be ready to help out poor little Freshies, to help push along the Juniors that they may become "mighty" Seniors, and help the Seniors keep their dignity long enough to graduate, trying on the whole to do our best to make Cedarville a bigger and better College.

M. Mc. 


\section{SOPHOMORE 'RAH}

Just a word about the meaning of our inharmonious name And the way the Ancients used it many years before we came; Note that we, as brilliant students of the cultured days of yore, Find that every Greek and Roman was a Sophomore.

Let us take the Greek word "sophos," meaning "wise,"-we've not a few, And the Hellenistic "moros," meaning "foolish," it is true; But we put the two together ("Soph" 's the end you underscore), Inconsistent combination; we get "Sophomore"!

It is hard for us to study when the Freshmen have a spread; Then we wander o'er the landscape when we ought to be in bed; So when some suspecting Freshie sees a shadow strike the door He calls wildly to his classmates, "It's a Sophomore!"

Oh, the Juniors may be boastful of their Hammonds, Thorns and Clarks. French and Greek for us are "pickins,"-in translation we are "sharks." Gentle reader, pray indulge us, have respect unto our lore, While we wrangle, rhyme and reason like a Sophomore.

We can't cease until the battle rages fierce on Senior ground, And our democratic spirit makes them turn their heads around, Till they deign to recognize that we are coming to the fore; Yea, till each one wishes he were "just a Sophomore."

But to talk about essentials in the coming work and strife, In a day when education is on trial for its life, In the studio, the pulpit, or upon the Senate floor You will find that Mr. Winner was a Sophomore. 


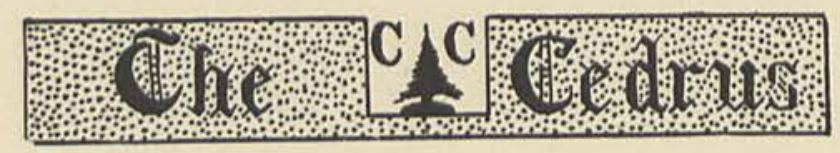

1921

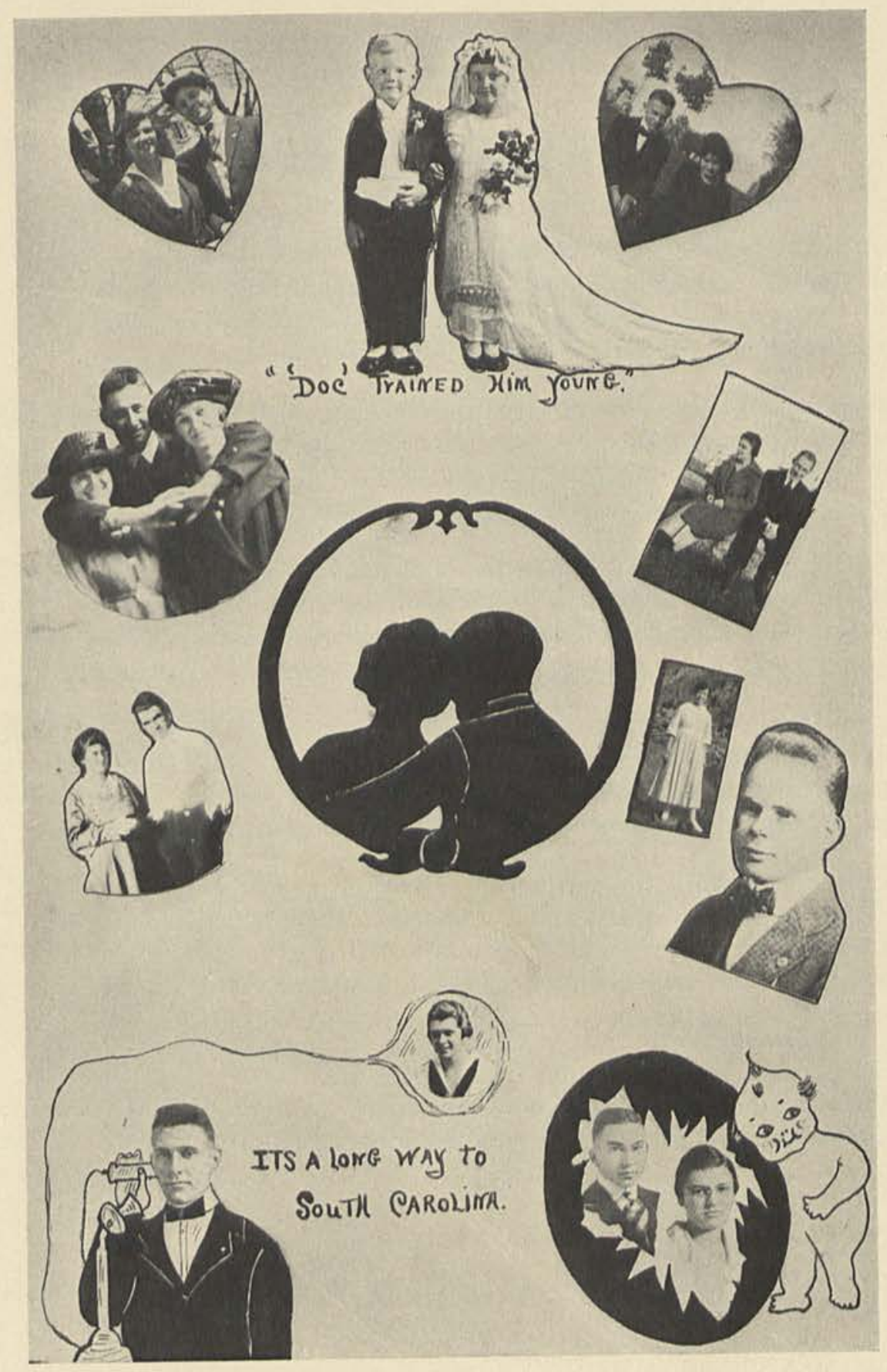



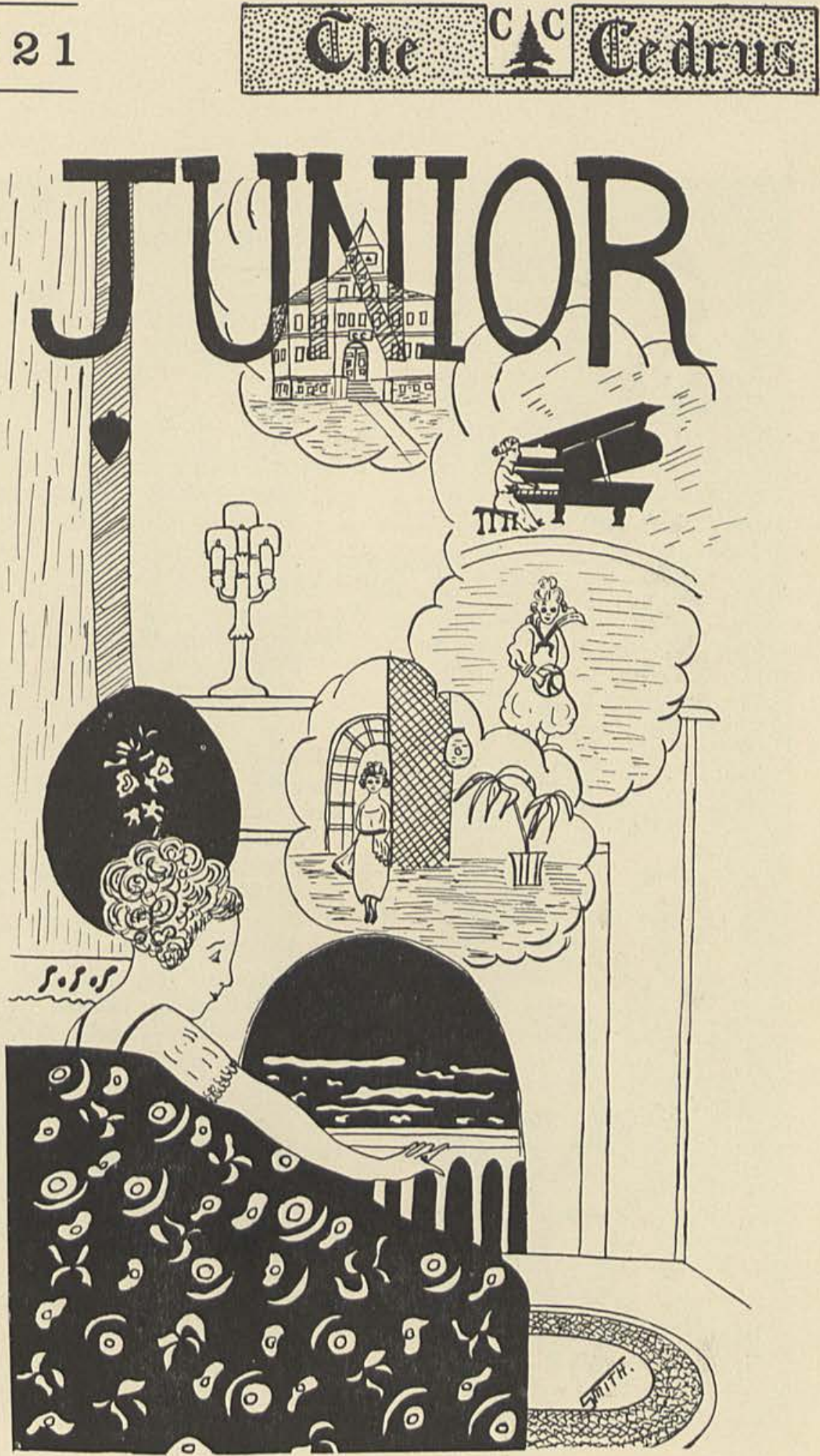

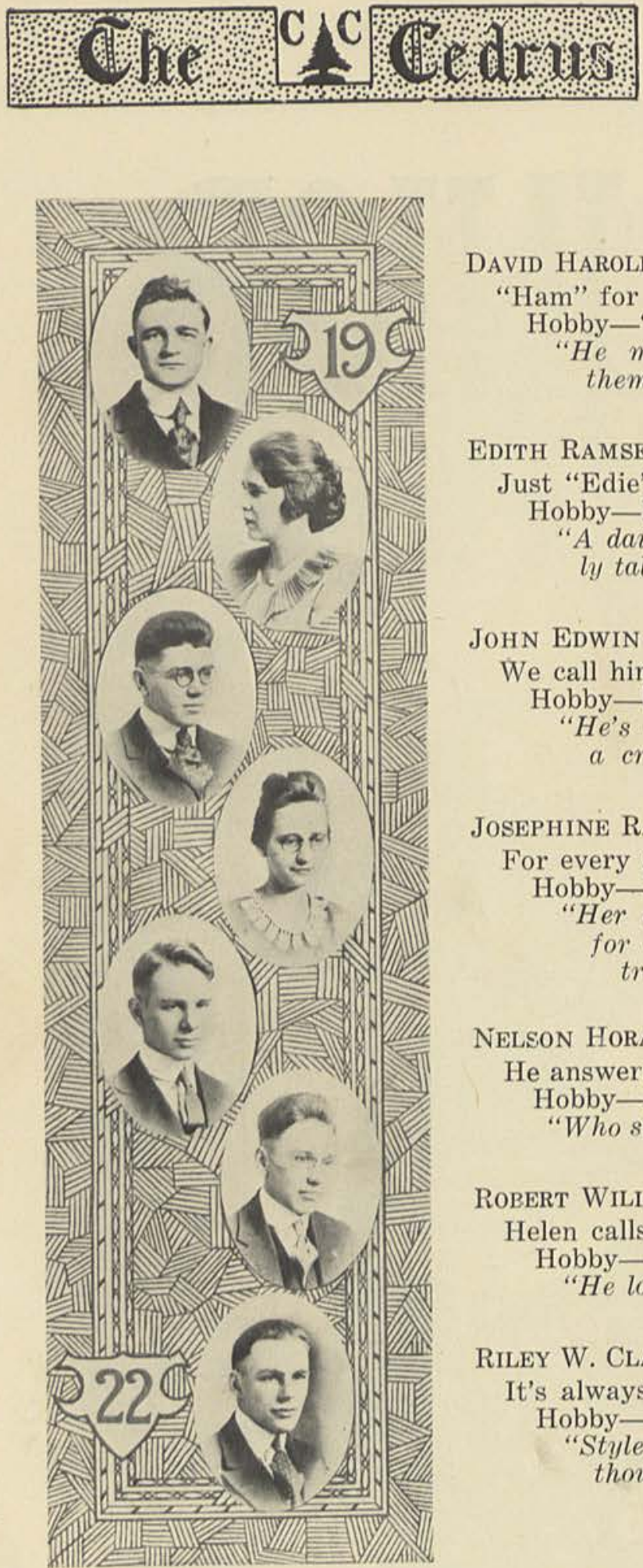

DAVID HAROLD HAMMOND

"Ham" for short

Hobby- "Park"ing on Miller St.

"He makes the least noise of them. all."

\section{EDITH RAMSEY}

Just "Edie"

Hobby-Being independent.

"A daughter of the gods, divinely tall, and most divinely fair."

JoHN EDWIN BRADFutE

We call him "Beef"

Hobby-being "Grace"ful.

"He's as lively and as noisy as a cricket."

JoSEPHINE RANDALL

For every day "Jo"

Hobby-Mathematics.

"Her days with joy are laden, for love of work is her chief treasure."

\section{NELSON HORATIO THORN}

He answers to "Nel"

Hobby-Keeping house.

"Who shall guess what I may be?"

ROBERT WILlard STEWART

Helen calls him "Bob"

Hobby-Going "out home."

"He loves but one at a time."

\section{Riley W. ClaARKe}

It's always "Clarkie"

Hobby-Making a good impression.

"Style is the dress of my thoughts." 


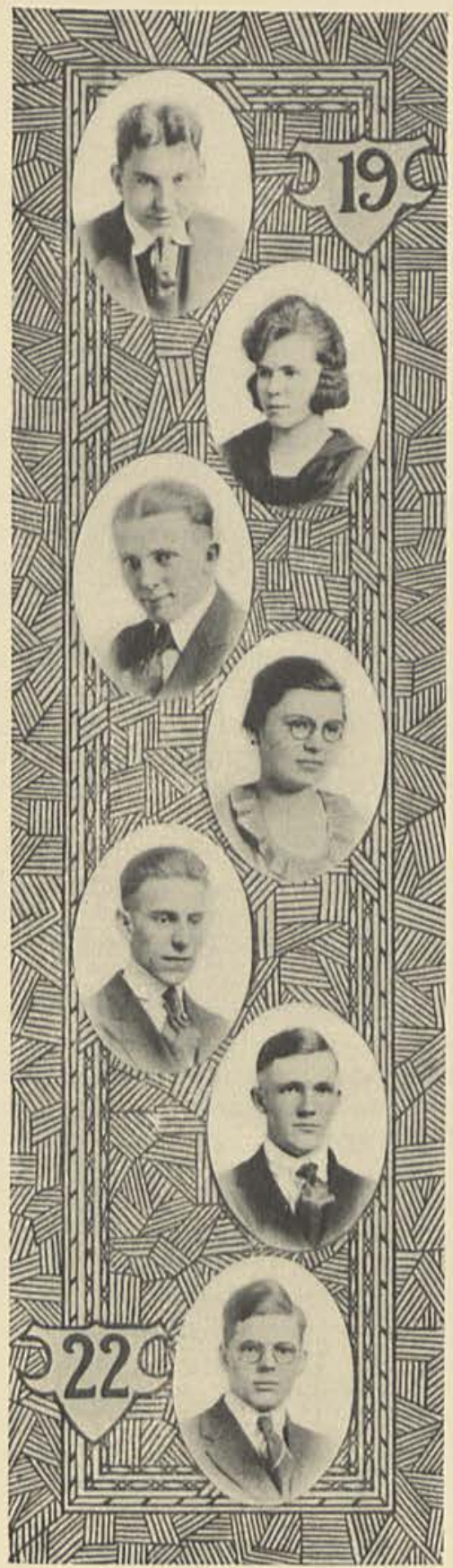

ROY FREDERICK INSLEY

Usually known as "Roy"

Hobby_Getting up spreads.

"An equal mixture of good humor and good sense."

Lillian Alice Daines

Just "Tommy"

Hobby-Reading mythology.

"A good sensible maiden whose duty combines with pleasure."

\section{WILLARD H. KYLE}

Always "Willard"

Hobby-Breaking the speed limit. "Strange to say he wears a bashful look."

\section{Margaret Elizabeth MCCARTy}

She's our "Peg"

Hobby-Keeping the 11 o'clock rule. "She makes a bright and cheerful chum."

\section{HARRY DALLAS WRIGHT}

Everybody calls him "Shorty"

Hobby-Dribbling the ball to C.C.'s basket.

"Life is short and so am I."

DAVID CECIL RIFE

Everybody says "Cece"

Hobby-Being funny.

"He who scorns a maid, must die a 'Bach'."

\section{RALPH LEROY RIFE}

He is just "Ralph"

Hobby-Doing his level best.

"Quiet, yet reliable, with hidden strength beneath." 


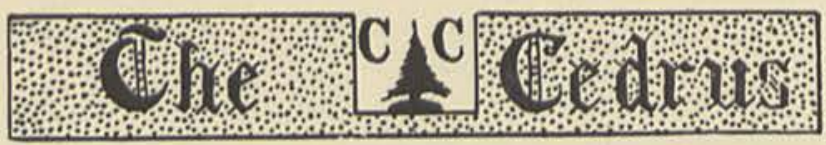

\section{THE JUNIORS}

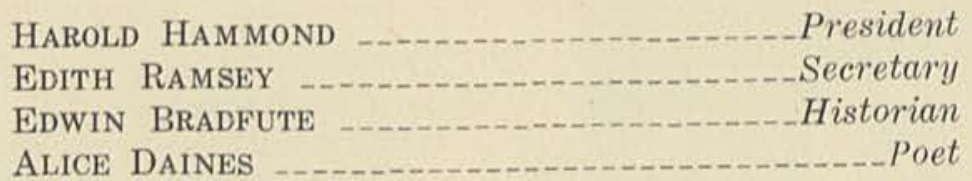

Class Colors: Scarlet and Gray

\section{COBWEBS OF TIME}

Time like an ever rolling stream

Bears all earth's sons away.

They die forgotten as a dream

Flies at the opening day.

Time is, was, and will continue to be. It is intangible, no one has seen it, or heard it, no one knows what it is, where it comes from, or where it goes. Any or all of us may use it, but whether we use it or not, it continues to go, and once gone it will never return, only the hollow mockery of its echoes are heard as it passes through the cloistered halls of the past on its fleeting way to eternity. Time is the governing factor of all things, the ultimate equalizer of all men.

Time works changes in us all. How well we remember our first day in school-the strange faces, the dragging routine-all is stamped upon our memories as if it were but yesterday. Then the first day of high school - the formation of new friendships - the gay, frivolous chatter and amid all these things we took our places for the first time among the true searchers for higher knowledge.

These two phases are however not as definitely marked as the great change into the cosmopolitan outlook of the modern college student. The catching sight of, for the first time, that vision-that mirage of greater service to our fellow-man, and the reaization that in serving others we serve ourselves to the best advantage.

Thus, amid the death agonies of a world conflict, in September, of nineteen hundred eighteen the class of ' 22 was born in Cedarville College, to share in her joys and sorrows and to participate in her activities. Verdant? Yes! As all Freshmen must be, but as time went on the green faded to the pale blue of the callow-minded, frivolous Sophomore. And now at last we are beginning to see the first faint rays of the lights of the Future. We are at last beginning to realize that the more we know the more there is to be known. Only one more golden mile post on the Appian way to the Rome of knowledge and we must assume the mantle of sedate Senior dignity. We approach it with a feeling of mixed joy and sorrow, joy in that we will be prepared to cope with the responsibilities of life and sorrow for the moments we have lost in idle play. We are by no means the largest class in our college, neither do we have the ego to say that we are the best (?), yet there is a certain distinction in knowing that we possess the spirit of co-operation both in the class itself and with the college authorities in an honest effort to place Cedarville College in its rightful place in the sunlight of fame.

Thus we see the Juniors as they were, and are, and what the years of the future will bring forth only time can tell.

J. E. B. 


\section{JUNIOR CLASS POEM}

Within the walls of old C. C.

The Juniors number ten and three.

Fearfully, wonderfully made are they;

If you don't believe it hear what I say:

Corpulent, skinny, large and small,

Married and single, short and tall,

Reckless and daring at naught we faint,

But go right on with our can of paint.

In spreads and smashups we delight;

We're in for fun as long as it's right.

When it comes to lessons we're hard to beat.

The profs say to teach us is a treat.

But we love our college, dear old C. C.,

With her competent help we will greater be

And in the future amidst the strife

We'll not be last on the ladder of life.

L. A. D. 

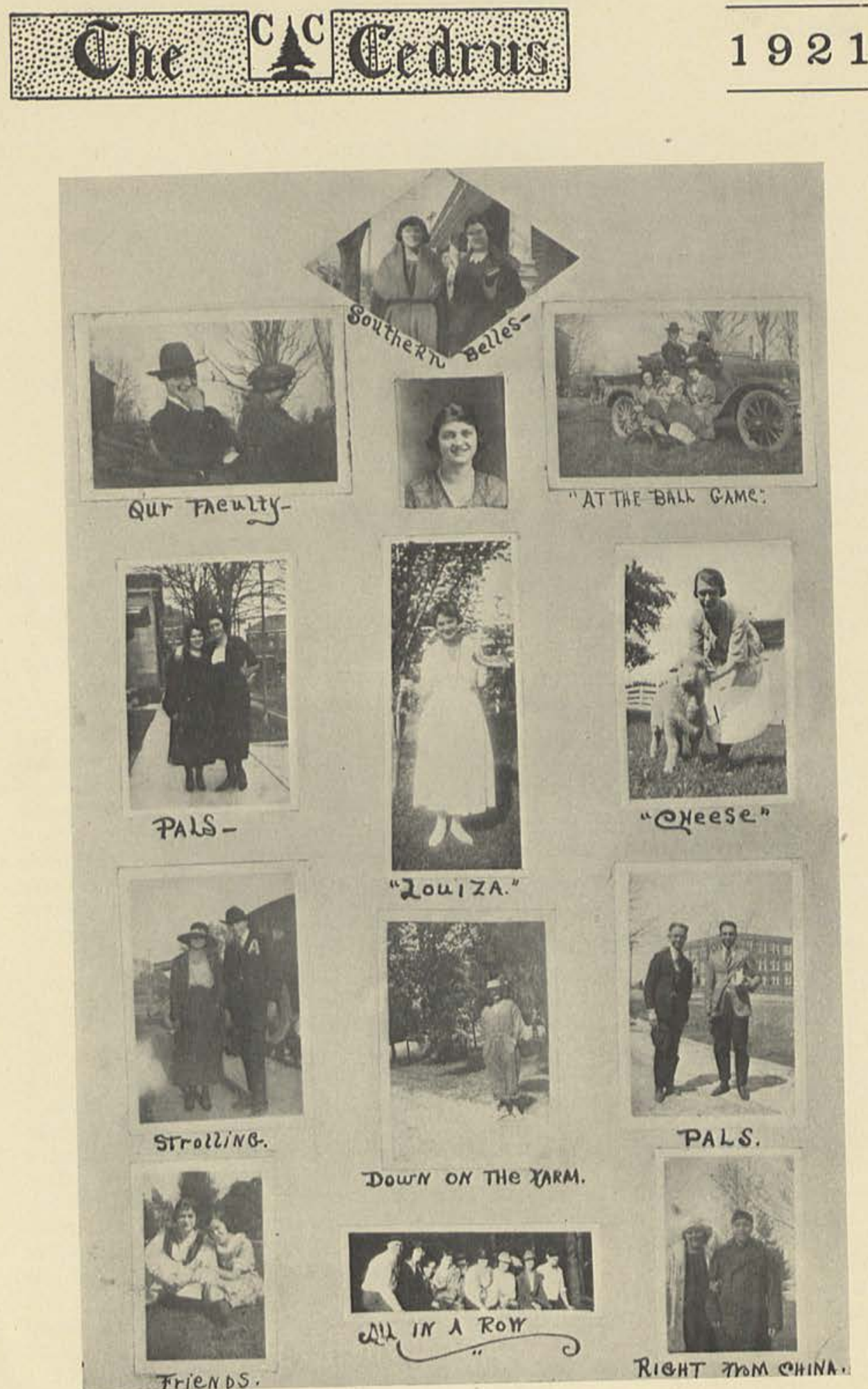


\section{1}
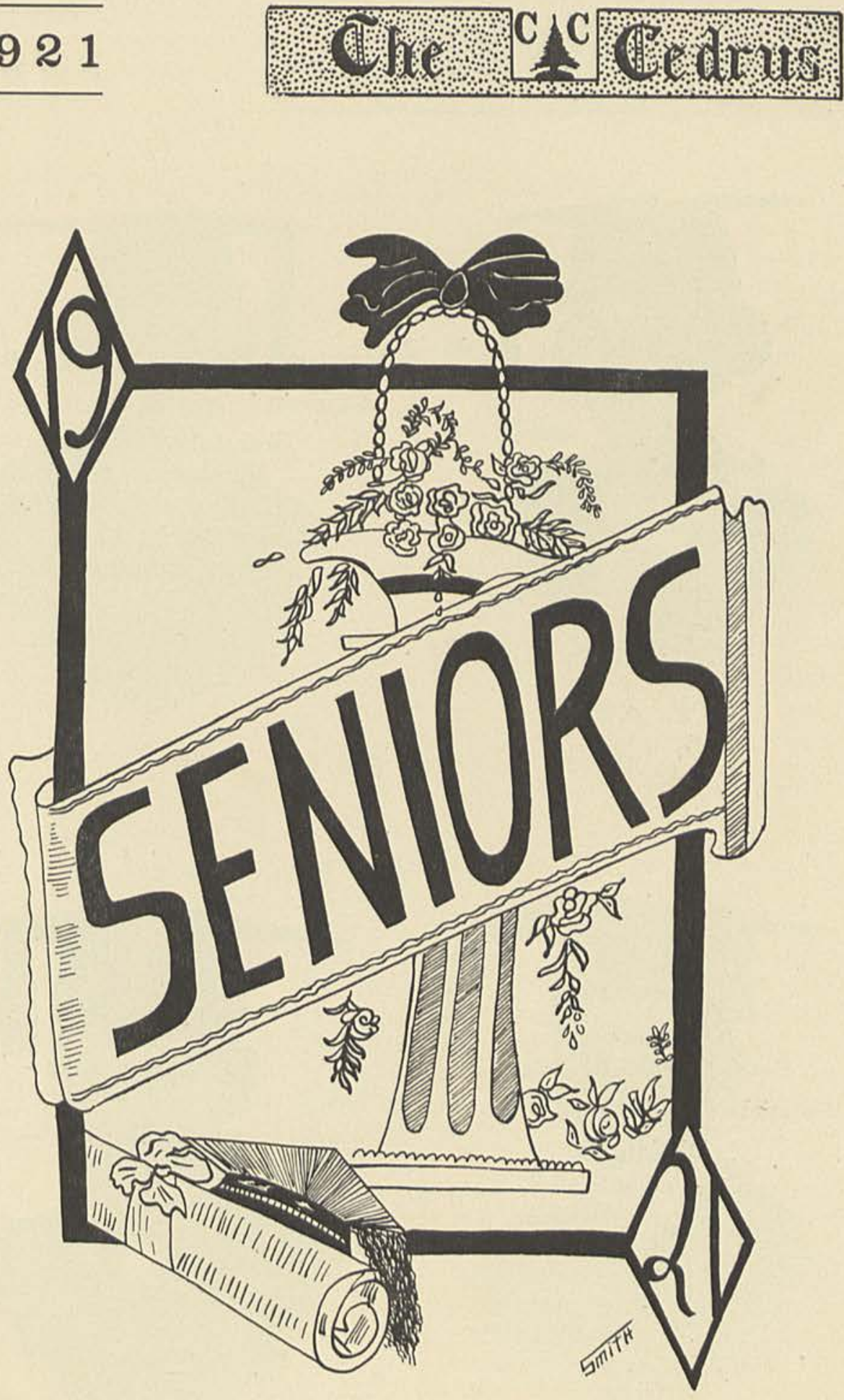

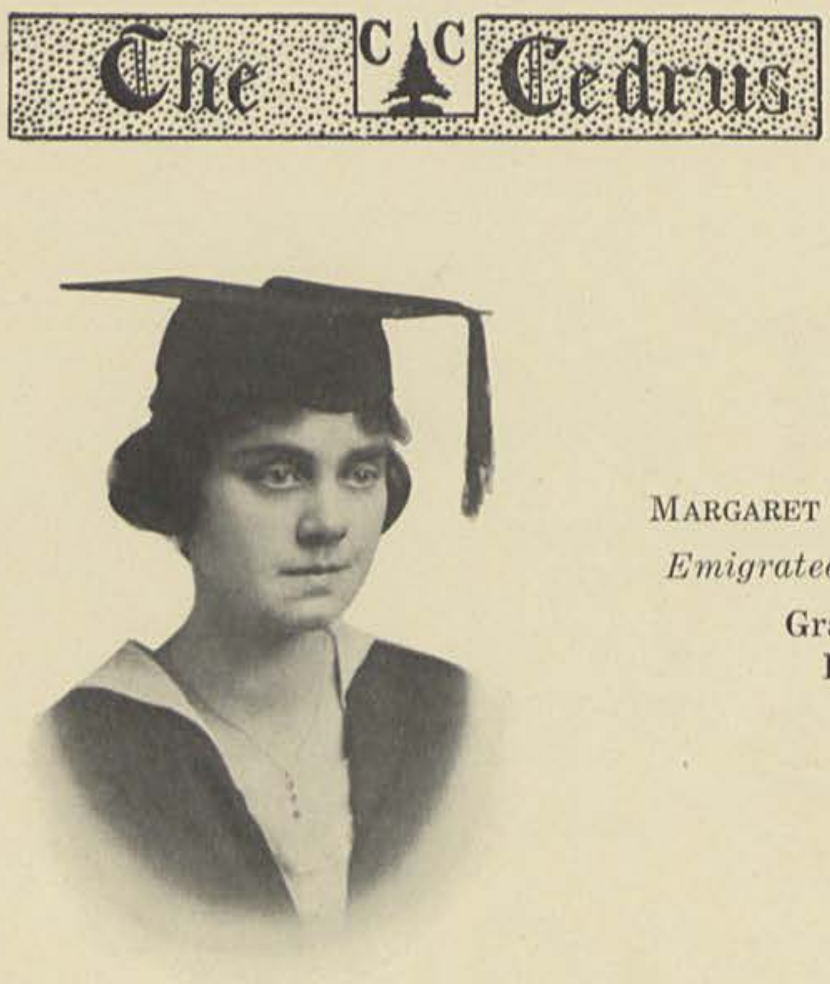

Margaret Louisa Greer, A. B. Emigrated from Pennsylvania

Graceful

Righteous

Engaged

Enchanting

Retiring

Paul Warren Duncan, A. B.

Originated in Western Pennsylvania

Diminutive

Unmarried

Neighborly

Cute

Artful

Natural

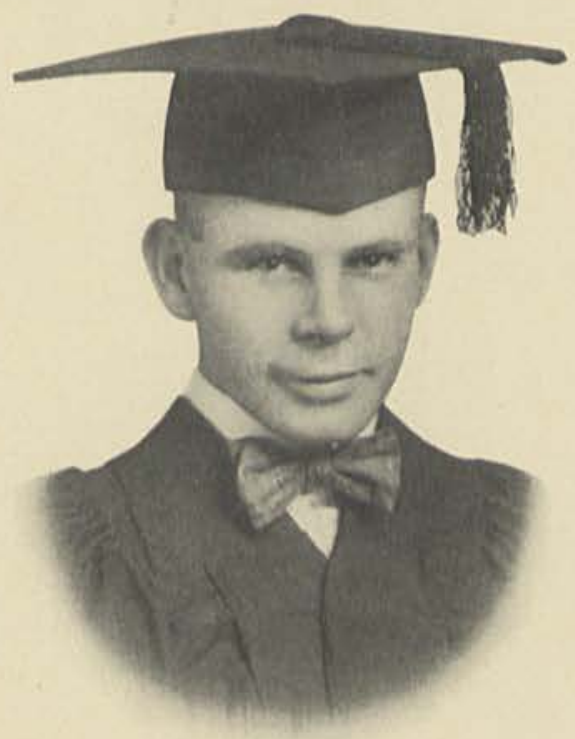




\section{1}
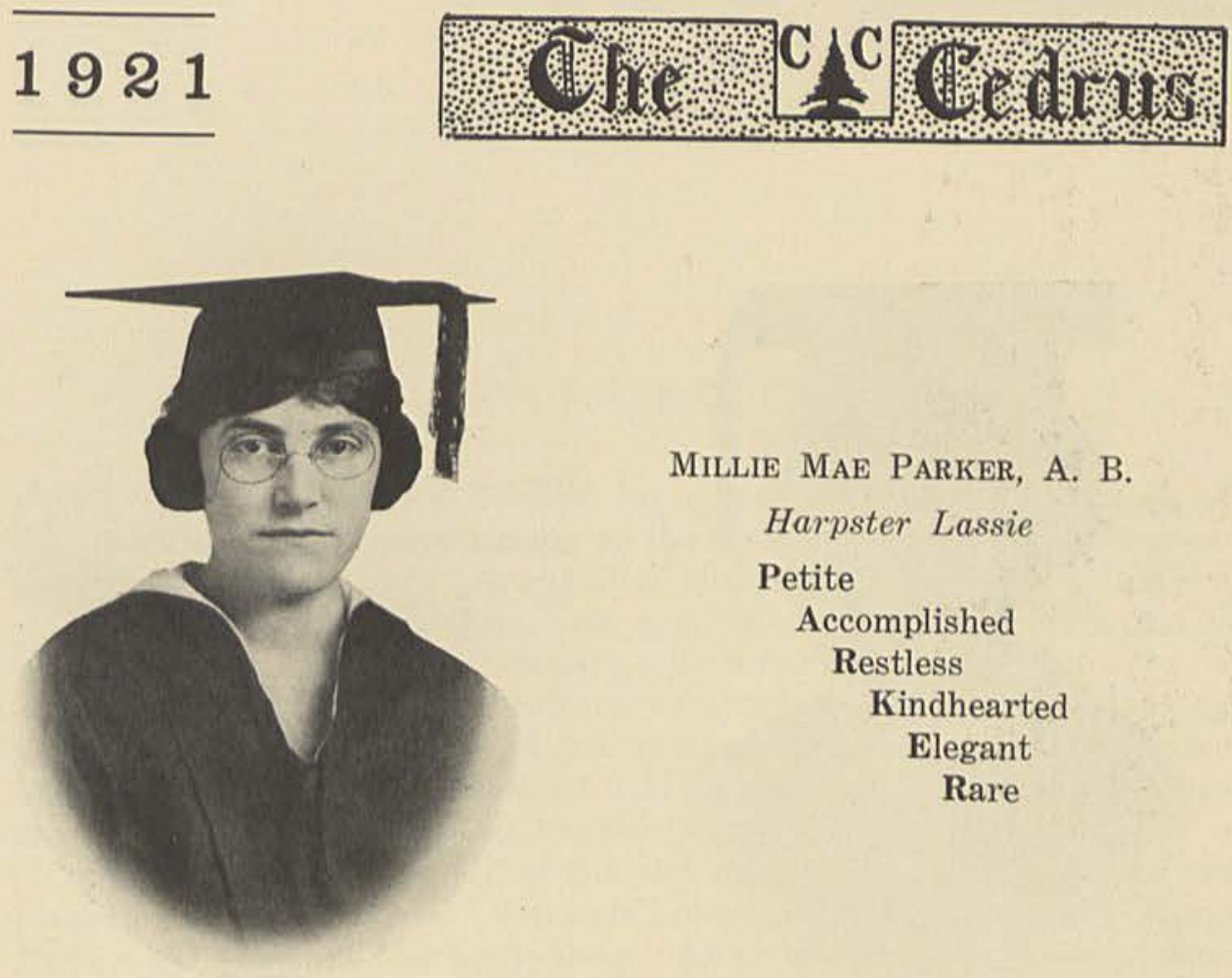

Millie Mae Parker, A. B. Harpster Lassie

Petite

Accomplished

Restless

Kindhearted

Elegant

Rare

Leslie Scott Dean, A. B.

A Product of the Farm

Dubious

Eligible

Agricultural

No Spendthrift

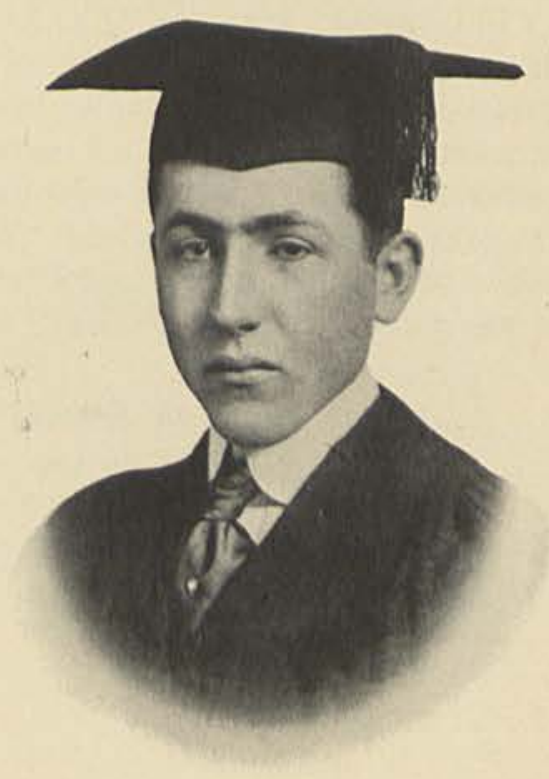



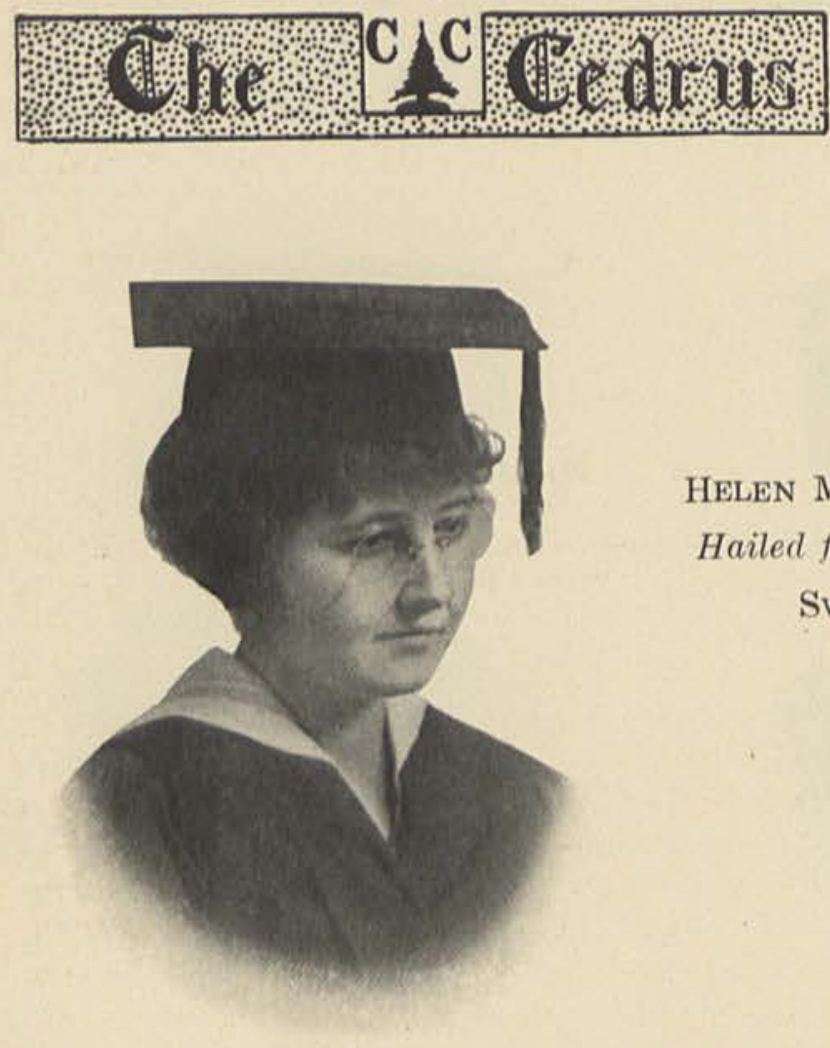

Helen Marie Stewart, A. B.

Hailed from Cedarville, Ohin

Sweet

Teacher

Energetic

Weighty

Affectionate

Round

Timid

DOROTHY TARR

Music

Cedarville High School

Tactful

Accurate

Reticent

Rotund

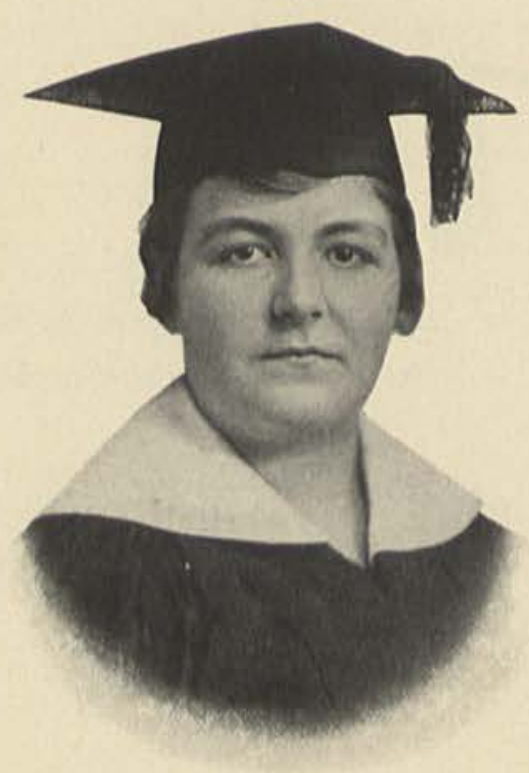




\section{SENIOR CLASS HISTORY}

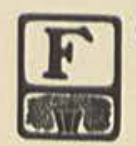

OUR years ago what is now the Senior Class entered the halls of Cedarville College to take up the tasks of Green Little Freshmen. This was a very jolly band of students. The work was quite a change from anything they had ever experienced before, but it was made more enjoyable by spreads, socials and receptions.

The next year when we entered as Sophomores we were joined by Louisa Greer. Many of our former students failed to return. Our country had called and they had responded willingly. By this time our class was very small but amid the difficulties we spent a very enjoyable year.

Our Junior year was full of life and fun. Only two members of the preceding class remained. We were joined by Helen Bradfute, Millie Parker, Paul Duncan and Leslie Dean. All of us remember the good time we had at Helen Bradfute's and also the spread we had at Clifton.

Now we have reached the top of the ladder. We have passed through all of the stages of a Green Little Freshman, a Boasting Sophomore, a Lovesick Junior, and have now acquired the characteristics of a Dignified Senior. Our number was again decreased, because Helen Bradfute was compelled to quit. Our motto is "QUALITY" and not "QUANTITY." As to quality, you can find no better. There is Millie Parker. Who could want a better person? Some day she will be on the stage impersonating different characters. Next is Louisa Greer, the most studious member of our class. She has devoted much of her time to the study of "Bushes" and some day will be a great naturalist. Leslie Dean ranks among the great Greeks and Romans in Oratory and Debating. Last, but not least, is Paul Duncan, known far and near as "Teasing Paul," who can not be surpassed for his speeches in Extempo.

We conclude in the words of the poet:

"We know the night is near at hand,

The mists lie low on hill and bay,

The autumn sheaves are dewless, dry;

But we have had the day."

H. M. S. 


\section{REVERIES}

Oh, what pleasant visions haunt us As we gaze back on the past!

All our friendships formed at C. C. For more we could not ask. Most of all those good professors Haunt us oft, and tarry long; When we think of all their patience As we tried to bluff along. Oh, what gladness, then what sadness As the thought steals o'er our minds That we must leave, like other classes, Those college days behind.

But as we sit so musing Another thought creeps in;

Though we are through at old C. C., In life's school we'll now begin.

So with God as our great teacher, Ever striving in his sight;

May we always be found walking

On the path of truth and right.

M. M. P. 


\section{1}
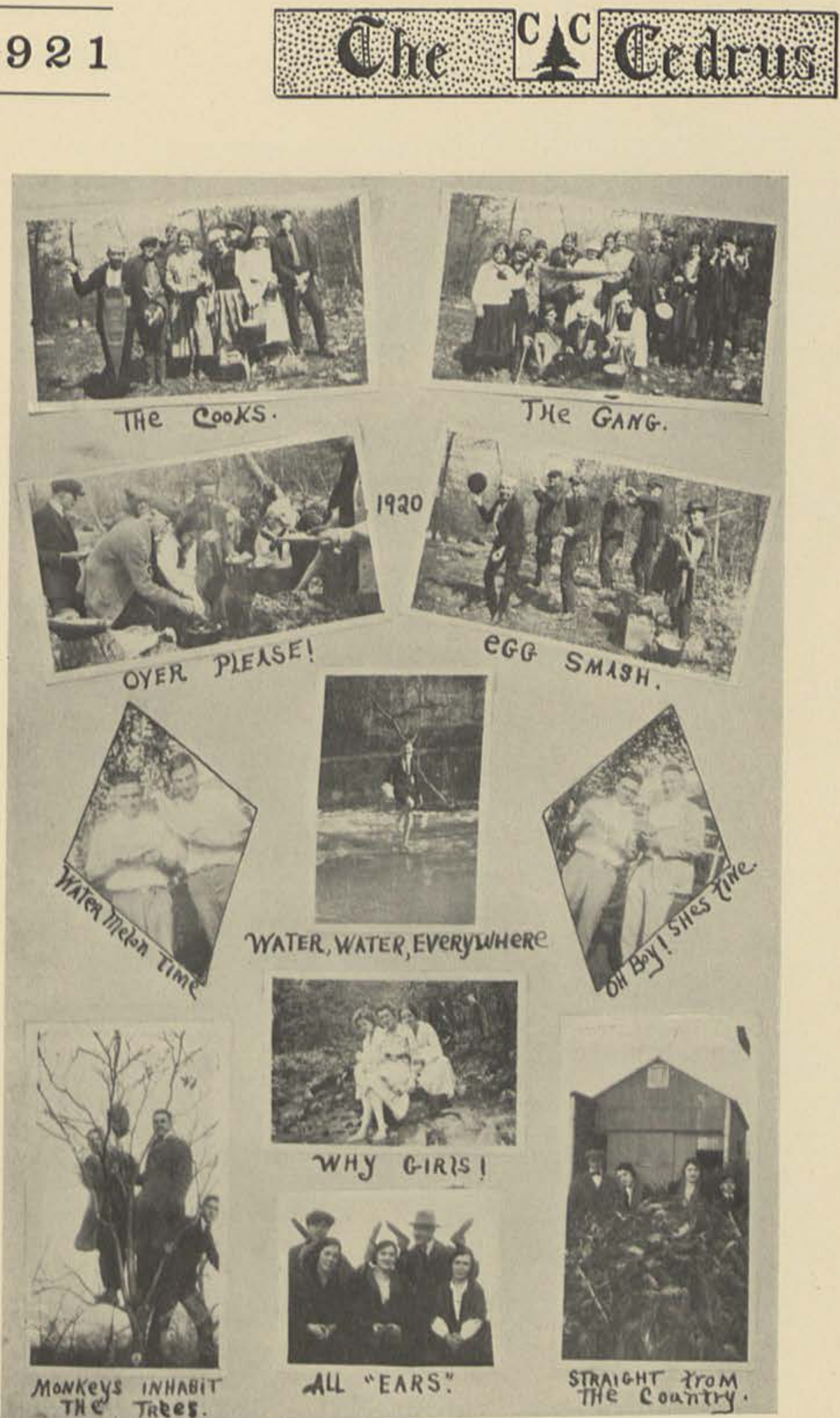

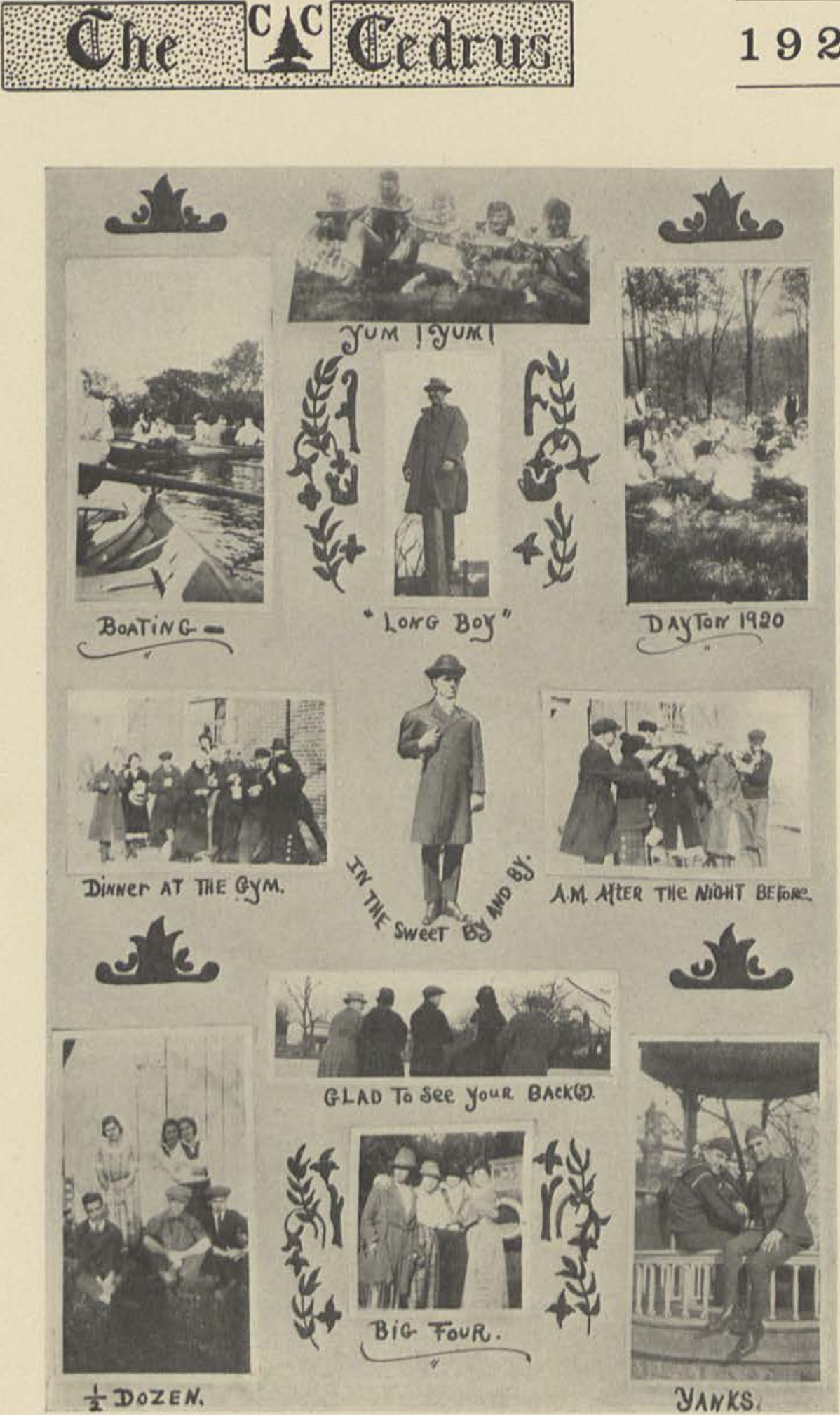


\section{1}
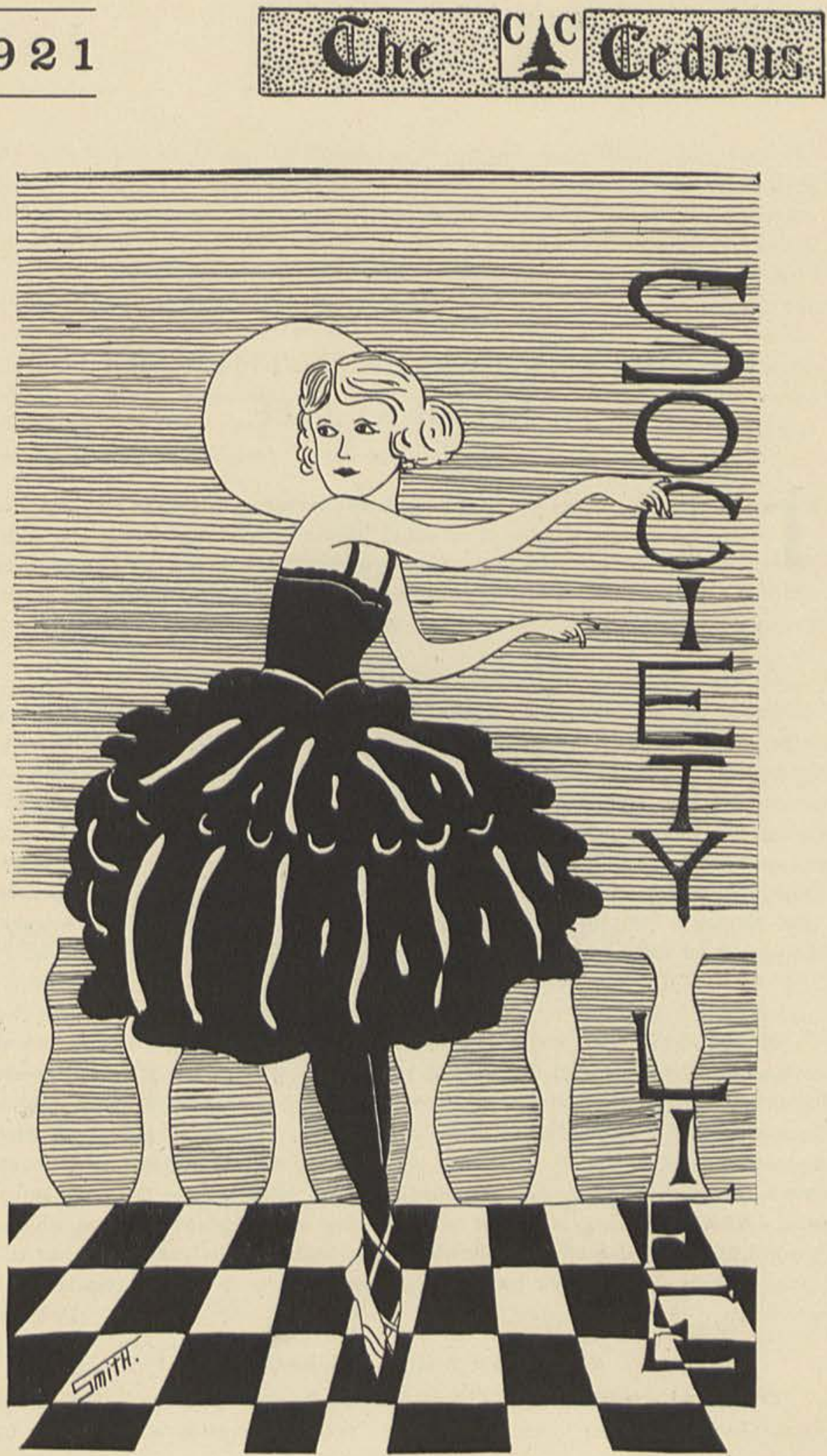


\section{IMPORTANT EVENTS IN THE COLLEGE STUDENT LIFE}

$\mathrm{HE}$ varied activities of the College do not permit us to give an elaborate account of all of the affairs of a social nature transpiring during the collegiate year. However, we will attempt to briefly recount some of the more important events, which together with the class spreads, parties and inter-class functions tend to round out the student socially as well as mentally.

\section{DR. AND MRS. MeCHESNEY ENTERTAIN}

One of the most enjoyable events of the season was the reception and supper given to the college students and faculty on the evening of February 11th, by Dr. and Mrs. McChesney. Their home was thrown open and all of us were made welcome. We mingled together laughing and chatting for some time and then were invited to the dining room where a delicious supper was served. We were then separated into groups, and each group gave a stunt, which every one enjoyed. A contest was conducted in which a box of candy was given to the one finding the most hidden paper hearts. After singing a few songs we departed at a late hour, very grateful to Dr. and Mrs. McChesney for their hospitality.

M. M. P.

\section{HALLOWE'EN SOCIAL}

On Hallowe'en the faculty and the boys of the College were entertained at the gymnasium by the girls of the College and faculty. Every one appeared dressed in fantastic costume. The interior of the gymnasium was very appropriately decorated for the occasion. A number of prizes were given. Miss Alice McKibben, who was dressed as a witch, won the prize for the most appropriate costume, and Charles E. Brown, disguised as an American Indian, won the prize for the most grotesque costume. After unmasking, all joined in the playing of old-fashioned games, which were followed by the serving of refreshments. About midnight the guests returned to their homes, feeling that the girls had made the occasion one to be long remembered as a rare treat.

D. C. R.

\section{CHRISTIAN ENDEAVOR RECEPTION}

The annual reception of the Christian Endeavor Society of the Reformed Presbyterian Church has come to be a traditionary event, anticipated with pleasure by the 
students and faculty of Cedarville College as they make preparations to return for another year of work and fellowship together. The reception, held September 17, three days after the opening of the present college year, marked the first of the many enjoyable social events of 1920-'21. During the first part of the evening it was a pleasure to see little groups collected in various parts of the room, laughing and talking, perhaps discussing the events of the summer vacation and bidding welcome to the new students. One of the most amusing contests centered about the search for the best conversationalist among the girls. The decision of the boys in favor of Millie Parker was practically unanimous. It is not to be doubted that the former studente and the newcomers left the reception, feeling that the spirit of Cedarville College and the loyal interest of the Christian Endeavorers were worth cultivating.

E. B. B.

\section{EPWORTH LEAGUE RECEPTION}

One week after the reception at the Reformed Presbyterian Church, the Epworth Leaguers of the Methodist Church royally entertained the students and faculty of the College. A number of carefully-planned games and contests were enjoyed. Groups of four or five were formed by matching parts of familiar songs. It was the duty of each group, while eating the two-course luncheon to practice the particular song which had been made by putting together the slips of paper. Concerning the songs, which each group was obliged to sing for the enjoyment of the others, suffice it to say that some were musical, some unmusical and some non-musical. At a late hour, as the last echoes of the music died away, all departed homeward.

E. B. B.

\section{UNITED PRESBYTERIAN RECEPTION}

On the evening of October 22, the students and faculty of the College enjoyed a unique and original theatrical treat, given by the Christian Union of the United Presbyterian Church. Ushers met the guests at the door and conducted them to special reserved seats. Soon the curtain was lifted which disclosed the mysteries of the theatrical managers. The splendid dramatic entertainment might be called a medley, composed of vaudeville, motion pictures, musical concert, grand opera and "darktown" minstrel. The thoughtful managers had even provided for the time-worn custom of a visit to the "Greek's" following the evening's performance. After finding partners all went to the Sabbath School room for refreshments. The carefully planned entertainment had certainly been a success.

E. B. B. 


\section{"WHAT HAPPENED TO JONES"}

The people of Cedarville found out what happened to Jones on November 19th, 1920 , when the following cast of characters played to a large and appreciative audience in the Cedarville Opera House. The play, as directed by Miss Brand, was such a success that it was afterwards produced at Ross Township High School and in the Spring Valley Opera House, during the following week.

Jones, who travels for a hymn book houze

LaClede Aloysious Markle Ebenezer Goodly, a professor of anatomy. Dwight Percy McKune

Anthony Goodly, D. D., Bishop of Ballarat. Carl Algernon Duncan

Richard Heatherly, engaged to Marjorie Riley Nehemiah Clarke

Thomas Holder, a policeman. Gavin Higginbottom Reilly

William Bigbee, an inmate of a sanatorium George Hezekiah Colman

Henry Fuller, superintendent of the sanatorium Earle Jehoshaphat Collins Mr3. Goodly, Ebenezer's wife. Florence Mehetabel Smith Cissy, Ebenezer's ward. Marjorie Sophronia Wright Marjorie, Ebenezer's daughter. Marjorie Jochebed McClellan Minerva, Ebenezer's daughier.... Louisa Angelina wreer Alvina Starlight, Mrs. Goodly's sister. Millie Patience Parker

Helma, a Swedish servant girl Calla Goodnight Turner

Between acts the following numbers were rendered:

Reading- "Sockery Kadahcut's Kat"

Anna Harper Male Quartet-"Popular Medley"

LaClede Markle, Carl Duncan, Willard Kyle and Harry Wright Vocal Duet- "'I he Ships 'i hat Pass in the Night"...... Lucile Johnson, Dorothy Oglesbee Reading- "Shadders" Edwin Bradfute Faculty Trio-Mendelssohn's "The Power Behind the Throne" Professors Jurkat, McElhinney and Allen

Other persons to whom credit is due for the above production are:

High Monkey Monk

Prof. Ethel B. Brand Fag Prof. Milicent Louise Hathaway

Grease Slinger Mr. Roy F. Insley

Wind Jammer.... Prof. Leroy Allen

Boodle Gobbler..... Mr.. Robert W. Stewart

\section{OTHER ATTRACTIONS}

In addition to the helpful and entertaining numbers of the Lecture Course, a Minstrel Show was given by the College talent on March 25th, 1921, and a Song Recital was given under the auspices of the College by Mrs. Franceska Kaspar Lawson, of Washington, D. C. She was accompanied by Miss Margaret Louisa Greer and Miss Mary Lucile Johnson. Her program was composed of classical airs, songs from other lands and familiar American songs. 


\section{1}
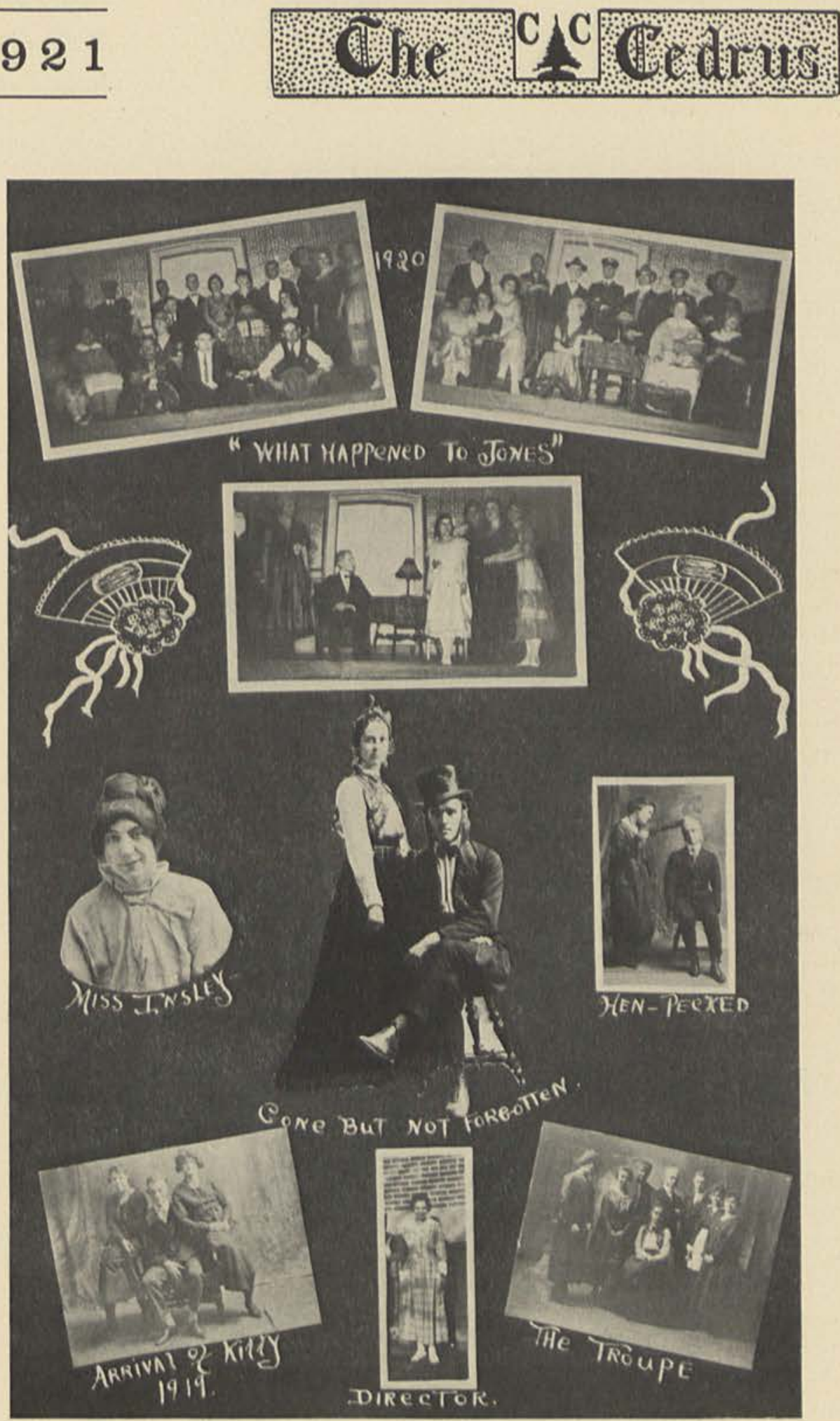


\section{THE GIRLS' PARADE}

Listen, my children, and you shall hear

Of the midnight parade of the lassies dear,

On the twelfth of October, Tuesday eve;

Scarcely a boy that did perceive

The cause of the voices whispering low,

The old moon looking down that night

Saw dark forms stealing from left to right,-

From South to North and from shade to shade,-

The girls were gathering for kimono parade.

Arriving at Ramseys, we had great fun

Laughing, "How slow boy's do catch on,

If they weren't so sleepy, they'd sure turn out

And stop this girls' spread without a doubt."

So we chatted on, eating pickles and cake

'Till the stroke of twelve by the dining-room clock

Warned us that it was time to stop.

Then we donned kimonos bright and gay

And merrily started on their homeward way.

When we came to the graveyard dark and still

With the moon-beams shining on the white stones tall

Our brave hearts within us began to fall,

Not from the fear of spirits walking,

So much as a college-boy 'hind a stone, gawking.

So we passed the soldier silent and grim

Without more fright, than slight quakings within.

When we reached the town, that memorable night

We had things fixed to make noise right;

Rattles and tins, shrieks and yells.

(Alas to say we had no bells)

Made them know that we were in town.

First the strange parade went West,

Serenading White and all the rest;

Markle and Colman, Stormont and Malin.

If they did not wake, it wasn't our failin'.

Next, we favored our professors stern

With cries of a slightly different turn.

In front of their homes we cheered them roundly,

We know they'd like to thank us, profoundly.

But let them, if they will, remember,

We tormented them less than they were in September.

As always, such fun must have an end,

So at twenty of two our ways we wend

Toward home and sleep for a little while.

And there's one thing about which we can boast;

That is, no one was left in the "cooler" to roast,

Because all felt a longing their mothers to see,

When the marshall yelled out, "Just you come with me."

M. A. McK. 


\section{A SUMMER EVENING}

A crescent moon, a lonely star;

A faint flush in the West;

A whispering wind among the leaves;

God's world at rest.

A drowsy child in tender arms;

A sleepy chirping in the nest;

A distant bleat of baby lambs;

God's world at rest.

$$
\text { L. A. D. }
$$

\section{A DAY DREAM}

I know that the distant hills are blue

With the kiss of the sunny sky.

I know that the shade is deep and cool,

And the white-tipped clouds sail by.

I know that the emerald vales dip low

To the edge of the winding stream

Where the pale blue flags of the Southland grow

And the silver minnows gleam.

And there, in the heart of the fairest vale,

Like a jewel that shines apart;

With the hands of fancy that cannot fail

I have builded the home of my heart.

$\mathrm{Oh}$, naught but Love and the summer breeze

Ever cross its sacred shrine,

And the blessings of Heaven, sweetly rests

On this little dream-home of mine.

L. A. D.

\section{THE DEPARTURE}

The summer days had slipped unnoticed past

While Life and Death were hovering near his bed.

His spirit wandered in those regions vast

That border on the land of all earth's dead.

With falling leaves his wondering soul returned,

And reason shone from out his sunken eyes,

Where love and sorrow and strange knowledge burned

For now he knew things hidden from the wise.

Then dimly shining through his pain he saw

A boat upon a river blue and deep

The Boatman at the helm was beckoning,

So, wearily he sighed and fell asleep.

L. A. D. 


\section{The Cedarville College Gazette}

\begin{tabular}{lcc}
$\begin{array}{c}\text { The Weather } \\
\text { Today - - Windy } \\
\text { Tomorrow - Windier }\end{array}$ & “ The Garden Spot of The Earth” & $\begin{array}{c}\text { P:30 a. m. } \\
\text { Twenty-sixth Year }\end{array}$ \\
\hline & Ppril Fool's Day, 1921 & EXTRA \\
\hline & Price: Cedarville, 5c.; Xenia, 10c. & Vol. VII \\
\hline
\end{tabular}

RAILROAD ROBBERY COMMITTED BY THEOLOGICAL STUDENT

On the night of February 11th one of the most unusual and daring incidents ever known to the community took place where, as it is alleged, Mr. Charles Brown stole a Pullman from the company to which it belongs. After much difficulty he succeeded in dislodging it from its usual position and taking it about the streets of the town. It seems that $\mathrm{Mr}$. Brown believes that the Pullman belongs to him, for when confronted with the accusation, his only statement, it is said, was "Iva Pullman."

\section{YOUNG SCIENTIST GIVES} POISON TO A STUDENT

Miss Milicent Hathaway, Professor of Science and Mathematics in Cedarville College, and known to many outside of College society, is said to have committed one of the worst crimes ever known to those in charge of the institution.

The victim of the crime, Mr. Harper Bickett, claims that while he was working in the Chemistry laboratory he went to Prof. Hathaway's desk to ask a question concerning his work. And that while there she knowingly and intentionally gave him several ounces of cyanide of potassium. The unfortunate victim is still living at this writing, although it was feared for some time that the strain produced by carrying the bot- tle of poison from her desk to his own might cause him to lose the use of his right arm.

\section{DEAN OF COLLEGE}

BEATS HIS WIFE UP

Professor Leroy Allen, popular and talented professor and theologian has been accused of beating his wife up.

It is alleged that the act was committed on Saturday morning, March 5th, at their home in Cedarville.

His intimate friends and neighbors all testify to the fact that in the past he has been a model husband and has always shown the greatest consideration for his family.

The only explanation that can be offered is that he had been so engaged with his college work during the past week, that it was quite necessary for him to rise at an early hour in order to complete the preparation for his sermon for the following day. He left on the $8: 15$ a. m. train for Cincinnati as usual.

\section{NEW REGULATION FOR \\ SECURING MAIL}

Due to the heavy mortality resulting from the rushing and jamming while trying to secure the weekly letter from the P. O. Box, it has been found necessary to use force in carrying out the idea of Safety First. Hereafter all students will fall in line, single file, before seeking to receive their mail. 
THE CEDARVILLE COLLEGE GAZETTE

\section{EXPOSE OF CONDITIONS IN CEDARVILLE COLLEGE}

Well founded rumors of a shocking state of affairs prevailing in Cedarville College during the past few years led the Ancient Order of Amalgamated Scandal Mongers, knowing that these reports must be true, because they always are, to appoint a committee of investigation to establish their truth. This committee did its work faithfully and well and submits the following authenticated and anonymous report:

"Your committee respectfully reports that after a careful, prolonged, and arduous inquiry, lasting through more than five whole minutes, it found the situation far worse in every respect than had been anticipnted. It discovered, for instance, that the students, and even, we are sorry to say it, the professors, believe in what they call a "democratic spirit." Under the impetus of this vague entity, the custom has grown up of the students managing their own affairs and even, scandalous as it may sound, of having their own chosen officers for this purpose. We were told, though we hardly know whether to believe it or not, that the faculty even consults the students on matters of common interest. But this we do know, that any student may rise to any position of honor or trust in the institution in spite of the mean position of his family or his lack of money. This is an insult and an outrage that should be remedied at once.

"Furthermore, and worst of all, in our opinion, it is declared to be an actual fact that the students are dominated by what the president of the said institution is pleased to call 'co-operation.' Shades of bye-gone student days-and nights! Whoever heard of the like? Instead of the respectable and dignified rough house of student pranks, class scraps, inter-society rows, and personal rumpuses and feuds that used to hang over the professors' heads (till the strings broke) with such a noble inscription as "Love one another," instead of these, allow us to repeat, we have today-'cooperation'! How a college run on such principles can be blessed is beyond us!

"The ideas prevailing among the members of the faculty we found exceedingly low and grovelling. Instead of lecturing, as they ought to be reminded they are paid to do, on the lofty speculations of the ancient philosophers and the beautiful conceptions of the classic poets, these misguided individuals seem to think that their function is to make the students do the work of their own education. And, by an ingenious system of devices, almost redolent of its brimstonic origin, they succeed in this to a most marvelous degree.

"One of the worst superstitions pervading faculty and student body alike is the strange belief that work and pleasure can be combined, that one may have a good time and yet do good college work. How such an idea ever got started is difficult to see, but so deeply ingrained is it now that to say a word against this popular notion is regarded as the rankest heresy.

"The moral conditions existing among 
THE CEDARVILLE COLLEGE GAZETTE

the students are simply appalling. The crowning proof of their perfidy and apostacy is the apotheosis of 'truth.' Obstinately refusing to be governed by authority, they wilfully insist upon facts. They refuse to acknowledge the self-evident truth that the opinions once established by the ancients are necessarily superior to anything that can now be evolved. In those days the process of thinking was infinitely simpler than now. The ancients could go right ahead and do their thinking untroubled by logic, science or facts (for such things had not yet been invented) and hence arrive unerringly at incontrovertible conclusions, which from henceforth and forever should constitute the sum of human wisdom and knowledge. Seeing that these things cannot be denied, students in all ages ought humbly and thankfully to accept them and go on their way rejoicing. But this the students of Cedarville College will not do. Students have been known to dare to ask questions of their teachers, and once or twice it has been reliably reported that a student differed from an opinion expressed in a text-book. Nay, even, it is asserted that the professors, to whom has been committed the sacred duty of safe-guarding the precious accumulations of the past from the sacrilegious and iconoclastic spirit of the present, tamely acquiesce and excuse themselves for their supine attitude by saying that their duty is to teach their students to think! What folly! Oh, for the oldtime pedagogue whose thunderous ipse dixit none durst question!

"Brethren and Sistern, it is evident that something must be did. We commend the institution to your tender mercy, and recommend clemency. Larger numbers of students are flocking to the college, enticed no doubt by the alluring character of the aforementioned vices that prevail there. Oh, the times and the morals! It will be sufficient, in our humble opinion, if this attendance is reduced. Mild and gentle measures are always best. We recommend that all students who even dream of attending Cedarville College be immediately put to death. If this be done, we doubt not but that the crying evils complained of above will at least be mitigated and we shall have to look elsewhere for trouble.

"Respectfully submitted by, YOUR COMMITTEE." 


\section{1}
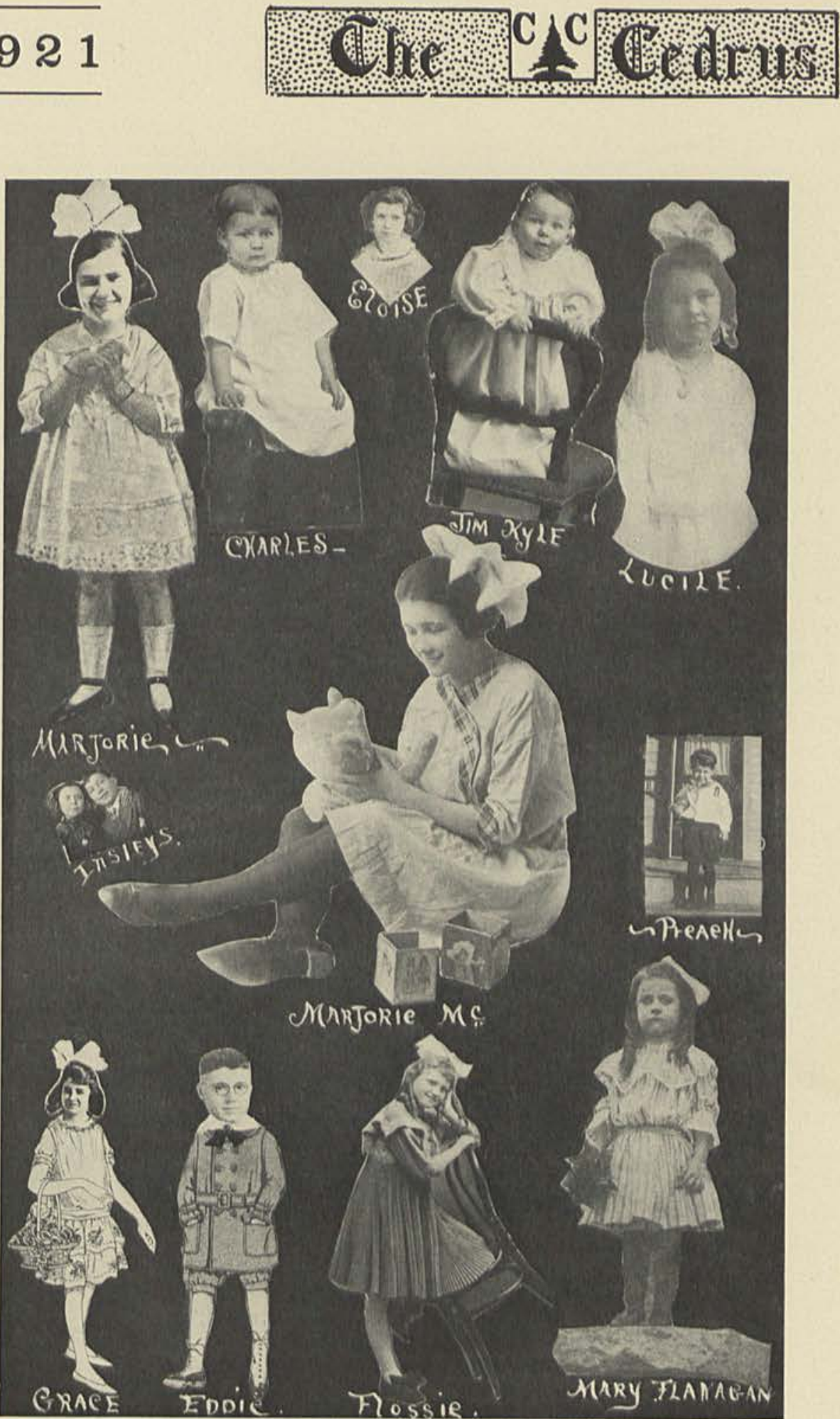

" AS WE ONCE WERE"

51 


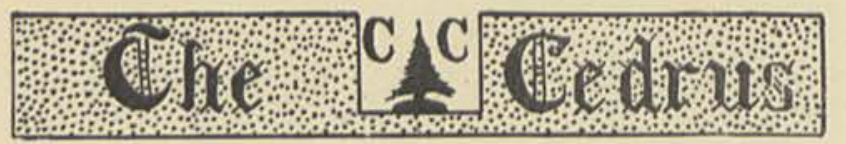

1921

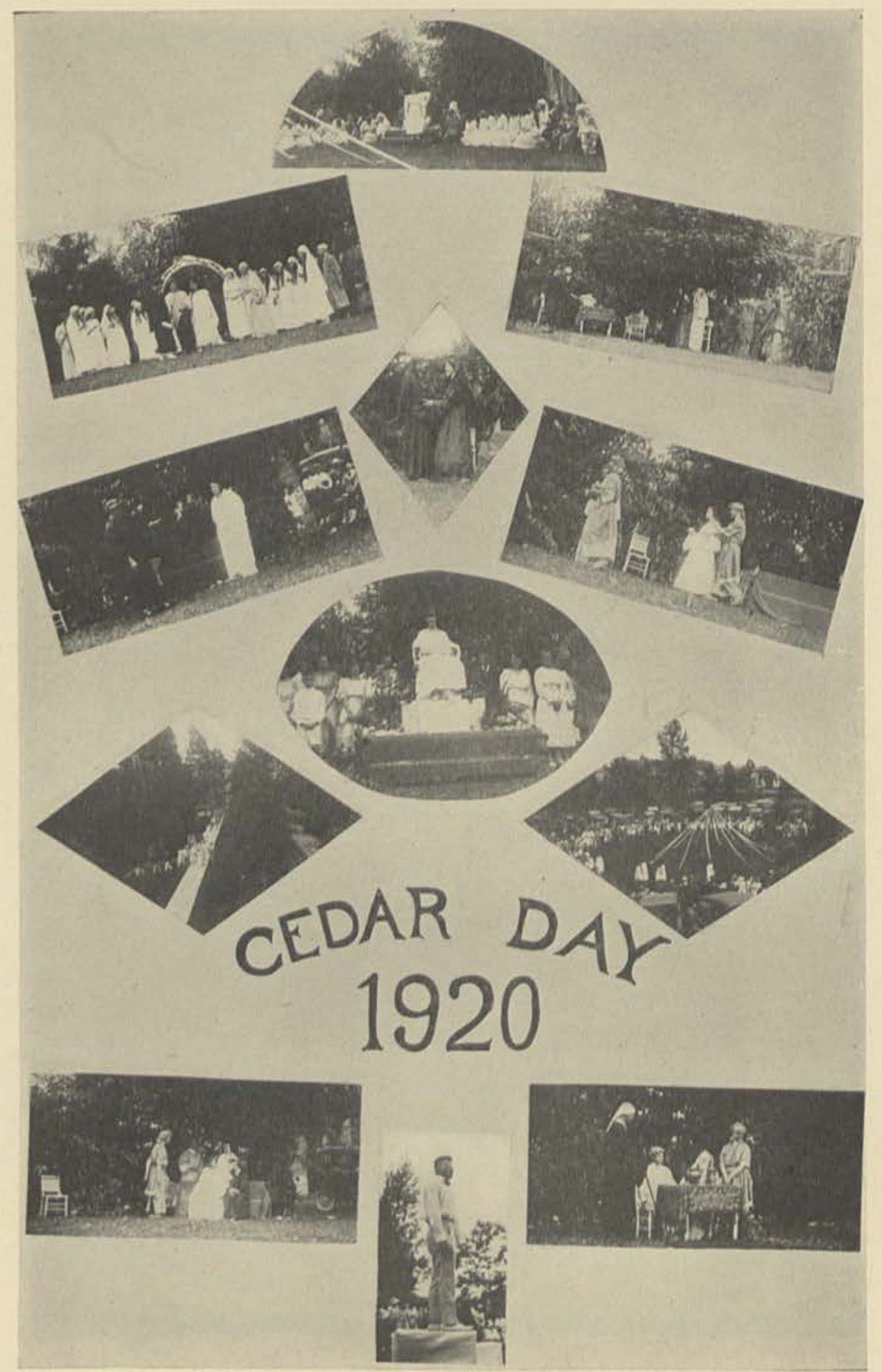




\section{1}

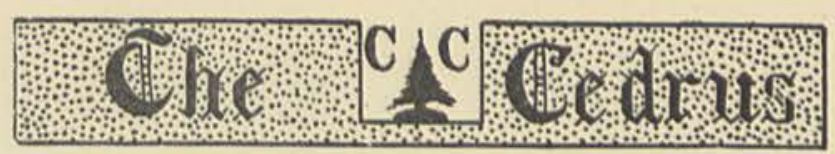

\section{CEDAR DAY}

$\mathrm{T}$ was the fourth of June. There was an air of expectancy about the campus. The birches along the walk swayed slightly to attract attention and the dew on the grass seemed to glisten more than usual. There were no classes being held in the college building. Everything was quiet except for a little group of students who were doing something mysterious with flowers and crepe paper. Something was going to happen.

At about nine o'clock, when the friends of the institution had gathered in a large circle at one side of the main building, they were attracted by the sound of music from an orchestra. Through the front gate and down the walk came a long procession, headed by her majesty, the queen, and her attendants. Next in line came a group of fairies in white. Following them came the nations of the world, each nation being represented by a boy and a girl dressed in their national costume and carrying their respective flags.

The procession having reached the circle, the queen was crowned with all ceremony due such an occasion. One by one each nation marched to the time of its national anthem, stood before the queen and bowed in submission to her. The fairies then entertained her by "tripping the light fantastic" about the May pole.

As soon as the queen could be gracefully dethroned, the spot was converted into an outdoor theatre. There the audience witnessed the play "Ruth," acted by a very Jewish-American looking troupe.

After the Cedar Day oration the audience and all the performers joined in a hearty picnic dinner.

H. E. B. 


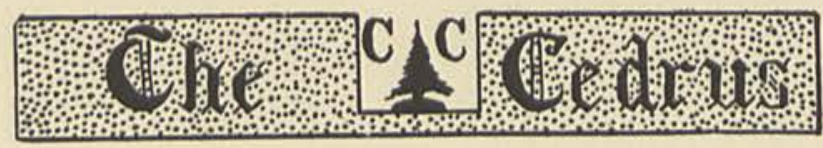

\section{SCHOOL SPIRIT}

BY HAROLD P. MYeRs, '24

10

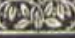

HE game was over and the "gym" was empty. In the dressing room Murray, the coach, and Captain Billy Owen, faced an uncomfortable boy.

"You mean that I was the cause of Fox Hill's defeat?" asked Steve Collins.

The coach nodded his head. The boy's flush became deeper.

"You mean that I purposely-"

"We don't mean that, but all the baskets were made by your forward."

"But I played the running guard, and made a couple myself."

"Steve," said Murray, "there are players who do so much and do it well, and again there are players who get tired out, but as soon as they hear their school yells given are ready to go into it harder than ever, that they may bring victory to their school, the one they love best. After your man made the basket that put them in the lead, I heard you come back to your position, humming."

"You mean I don't care," asked the guard.

"No, I won't put it that way," said the coach, "but just how sorry were you when that final whistle blew and the game was lost?"

"Well, I was sorry."

"Sorry! I've had boys who would have cried like babies."

"Well-I-"

"That's just it, Steve." The coach sighed as he said it. "You haven't what is called school spirit, and without it you cannot put up your best brand of basket ball."

Steve looked straight at the coach. "Are you going to put me on the second team?" he asked.

"I am afraid so," the coach replied.

"How long does it take to get school spirit?"

"It all depends."

"If I get it, shall I let you know?"

"You don't need to," replied the coach, "I will see it."

Steve walked over to the dining room, and in spite of his downfall, ate a hearty 


\section{1}

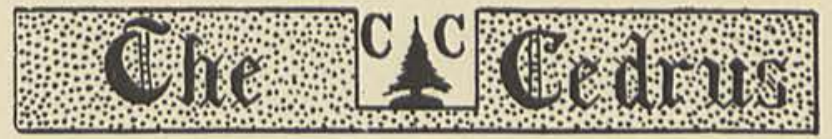

supper. Afterwards in his room he vowed he would try to get the thing that the coach said he lacked.

At practice, Van Winkle took his place at guard, and he played substitute. $\mathrm{He}$ tried to get the school spirit by becoming wildly excited at practice and by trying to get wrought up over the next game from the bench, but all efforts failed.

In discouragement, Steve went to the coach and told him his story.

"You can't force it, Steve," replied Murray, "When it comes, it comes. That's all."

"I hope it comes soon," said Steve gloomilv.

Just three games to play were left on the schedule: Tarlton, Mapleton and Chafin. The boys began to get nervous at the practices and excitement ran high in the school, because it was whispered that Fox Hill didn't have a chance against Chafin.

Steve heard all these rumors, and was somewhat anxious, but he did not feel the dread that the other students of Fox Hill University felt.

Then came the Tarlton game. Tarlton had held Chafin to a tie at the end of the second half, but had lost by two points in the five minutes overtime. She came to Fox Hill ready to annex another victory to her long list, but Fox Hill won. All in the dressing room that evening were nervously excited, but Steve felt that he was out of all this, and that he was missing a lot of fun. There was only one more game before the big game at Chafin. Excitement ran high through the school until Mapleton came and beat Fox Hill twenty-two to fifteen.

Steve walked across the floor with his head down. At the door of the dressing room he bumped into somebody and looked up. It was Murray. "Tough luck," said Steve, and Murray thoughtfully rested his chin upon his hand for a moment.

The last week of the season had arrived. It found Fox Hill weak and shaky. Monday's practice netted nothing but poor passing and few good shots at the baskets. That night Van Winkle complained of a pain in his side, and the next morning the whole school knew that Van had appendicitis. Now Steve must go into the big game. The coach came to him the next day and told him to report for Varsity practice for he would play in the Chafin game.

After Friday afternoon's practice the team caught the 6:10 for Chafin. When they arrived in Chafin they immediately went to a hotel. Steve bought some newspapers to read in his room. He started to read the account of the game to be played the next evening, but all that he saw was line after line, paragraph after paragraph, telling about the weakness of the Fox Hill team. In anger he cast the paper from him. Couldn't any of the sport writers give Fox Hill a kind word?

The next afternoon they went to the gymnasium to get a line on the floor and baskets. They shot a few fouls, but were not on the floor long. 


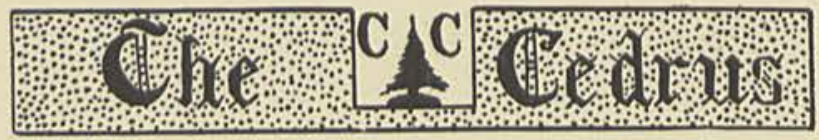

An hour after supper the boys went to the dressing room at the gymnasium. After Steve finished dressing, he waited for the others. His heart was doing queer stunts underneath his ribs. Captain Billy led the team out on the floor, and from the Fox Hill section came a cheer from the few rooters who had accompanied the team. The boys started a little pass-work and basket shooting to get warmed up before the game.

Suddenly a group of red-sweatered, red-stockinged players came running upon the floor from the Chafin dressing-room. The stands arose with a roar. For a moment Steve was stunned. The yell that Fox Hill received was very small compared to the thunderous roar that greeted Chafin. Then, almost before Steve realized it, the big game was on. The ball was tossed up at center and the Chafin center got the knockoff. Then Chafin got the ball and by some neat passwork and some neater shooting annexed the first basket in short order. After the ball had been knocked off the next time, a foul was called on a Chafin player for traveling. Captain Billy shot the foul and the score stood 2-1, in favor of Chafin.

Then both teams settled down to real work, and few baskets were made on either side. Steve had heard one of the Chafin players at the first of the game tell what a cinch they had with Fox Hill and that their scrub team could have beaten Fox Hill's team. This aroused Steve's fighting blood. He was like a streak of lightning. He seemed to be almost a part of the ball, he followed it so closely. Nevertheless, Chafin had two unbeatable forwards and a center that could shoot baskets from any part of the floor.

In the last part of the first half, Steve got a bad fall which bruised him up and dazed him for a few moments. When the whistle blew for the end of the first half, he felt that he had played all he could under any circumstances. The score stood ten to seven in Chafin's favor. Steve went to the dressing room for a rub-down. While lying on the table having his sore and stiffening muscles kneaded, the coach came up and put his hand on Steve's shoulder and told him to listen. From out on the stand, came the Fox Hill college song. It sounded better to Steve than it ever had before. He jumped down from the table and seemed to have more pep than before he got hurt. He had meant to tell the coach he couldn't play the second half, but now he had forgotten all about that, and as the referee blew the whistle for the second half he jumped to his place with a determination to fight written all over his face.

The second half started fast and furious, with Chafin playing the offensive, and Fox Hill trying to break up their clock-like passwork. Steve caught the ball, meant to be passed to the Chafin forward, and shot it down to Captain Billy under the basket and he made it. The score board read-Chafin 10, Visitors 9. However, after this Chafin was more careful and tightened up on their guarding. The Fox Hill rooters 


\section{1}

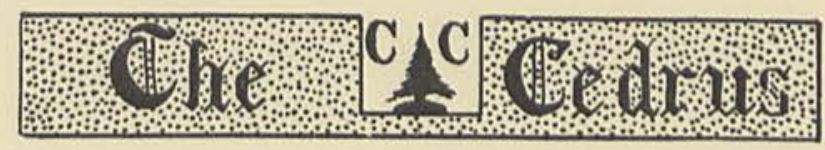

yelled wildly for just one more basket but it seemed as if their pleadings were not going to be heeded. Steve ran after the ball in the last part of the second half and a big Chafin guard ran into him with all of his force. This knocked Steve down and he hit the floor with a loud thud. Captain Billy called time out and all the Fox Hill players ran over to him after they saw that he did not get up. He was stunned by the blow. After cold water was thrown on him he came to and the first thing he heard was the call from the stands:

\section{"Fight, Fox Hill! Fight, Fox Hill! \\ Fight, Fox Hill! Fight, Fight, Fight!”}

All at once Steve's muscles began to throw off their slowness at rising. His head cleared. He asked some one how long there was yet to play. They told him forty seconds. Forty seconds more and the score still against them! The coach whispered something in his ear, but he did not hear him. He went back into the game with new vigor. The ball was tossed up. The Chafin center got the knock-off, as he had almost every time throughout the game. He knocked it toward Steve's forward but Steve jumped high in the air and got the ball. There was a Chafin guard in front of him but by a clever dribble he got past him, and now none of the Chafin players were between him and the basket. He was not much of a basket shooter, but both of the forwards were being closely guarded, and that ball had to go through the net. He took careful aim and shot. The ball went high into the air, fell on the side of the basket, and, after spinning around the hoop, dropped through.

The Fox Hill rooters went mad. Steve's overworked museles refused to act any longer. He dropped to the floor. Captain Billy called time out, and a "sub" was put in for the few remaining seconds, but the time was too short for Chafin to score. The final whistle blew with the score of 11 to 10 in Fox Hill's favor. The game was won for Fox Hill and Steve was the hero.

Steve soon recovered consciousness in the dressing room. The coach was standing over him, and the team was gathered around him.

"Boys," he said, "I know now what school spirit is, and I have it."

(Awarded first prize by Reviewing Committee). 


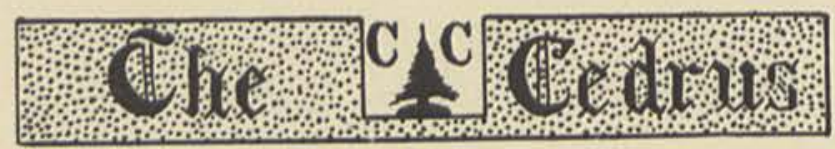

1921

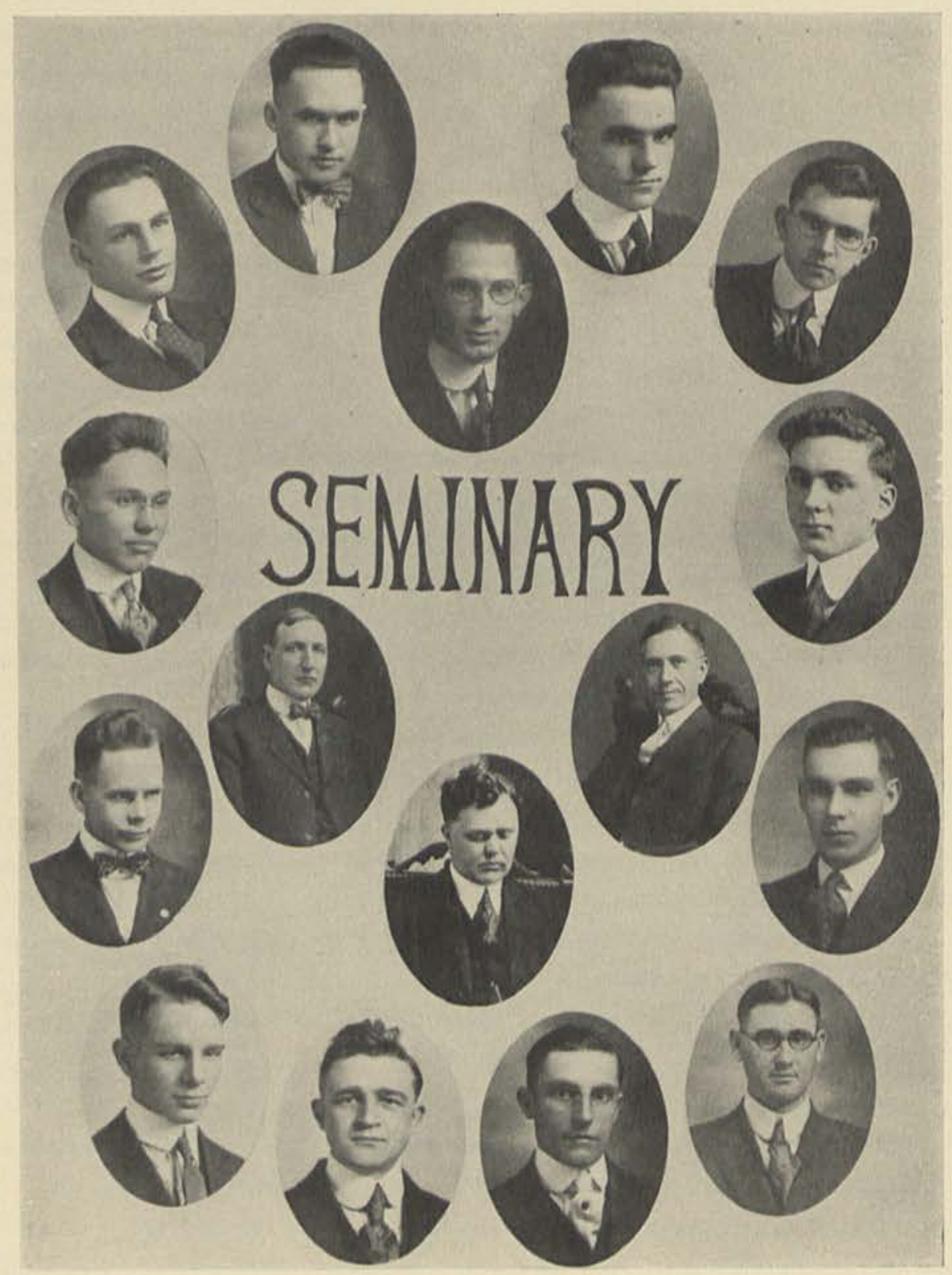




\section{FACTS AND ACTS OF THE SEMINARY}

EPTEMBER, 1920, saw the beginning of the eighth year of the Reformed Presbyterian Theological Seminary in Cedarville; and, also the one-hundred-and-tenth anniversary of its organization, which was accomplished at Philadelphia in 1810. But with all honor and regard for the Past, and especially for those pioneers whose recognition of the need of a trained ministry and of the Power Who provides that ministry enabled them to conceive and to carry out plans for this institution, we wish to suggest some of the activities of the 1920-21 personnel. May those who laid the foundation have builded better than they knew.

With the loss of two of last year's class by graduation (we trust our loss is the world's gain) and the addition of a new member, this body now numbers fourteen, one of whom is absent because of illness. In addition to those who are preparing for the ministry at home and abroad, a number of students from the collegiate department are taking seminary subjects.

After the Christmas vacation the organization began a very important work. According to pre-arranged plans, we proceeded to act upon the responsibility and privilege which had come to us, and are now engaged in teaching sixteen large Sabbath School Classes of boys and girls in the Ohio Soldiers' and Sailors' Orphans' Home at Xenia. This is made possible through the assistance of students from the Collegiate Department who act as teachers or substitutes. The mutual respect and love of Bible Study is of increasing benefit to teachers and classes. We are indebted to Dean McChesney for help on the Sabbath School lessons, given in his splendid Saturday evening lectures.

Seven o'clock A. M., on Friday, does not sound like a favorable hour for a meeting, but it is nevertheless a customary one for the weekly devotional meeting of the organization; these are "times of refreshing."

Most of the students are doing regular or occasional preaching at various points in Ohio, Indiana and Pennsylvania. During the past summer vacation several did missionary work in Kentucky, Michigan and New Mexico. May we lengthen our cords and strengthen our stakes.

$$
\text { C. E. B. }
$$



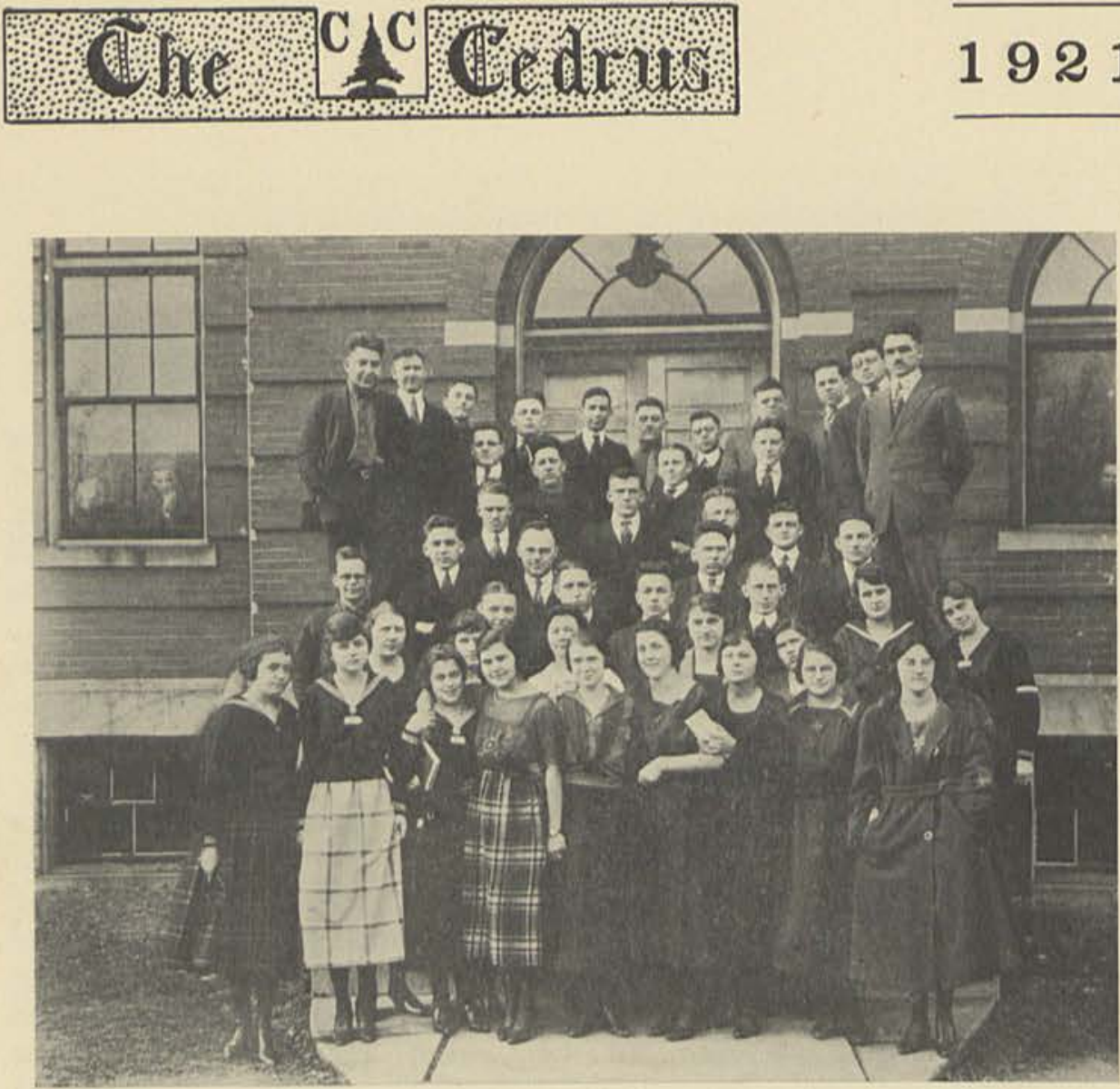

\section{ORANGE AND BLUE LITERARY SOCIETY}

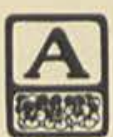

FTER we have been studying our books and hearing the Professors express their thoughts for a time we like to have a chance to express our own. For this purpose the former students of Cedarville College saw fit to organize the Orange and Blue Literary Society. This socjety offers every student who enters College, a chance for this training. (The society meets every two weeks. The entire student body is divided into sections so as to give every student a chance to perform at least once a month. There are committees for arranging the various parts of the program. Practically the entire student body is represented in the society. An attempt is made to make each program as original as possible through having original poems, original composition of songs, impromptu speeches. A college journal is also produced at each meeting wherein jokes, current events, and amusing things that happen among the students are given. The college year 1920 and 1921 marks the most progressive year in the history of the Orange and Blue Society. The majority of the students are anxious to take advantage of the splendid opportunity, which the society offers for training.) $\quad$ C. B. T. 


\section{1}
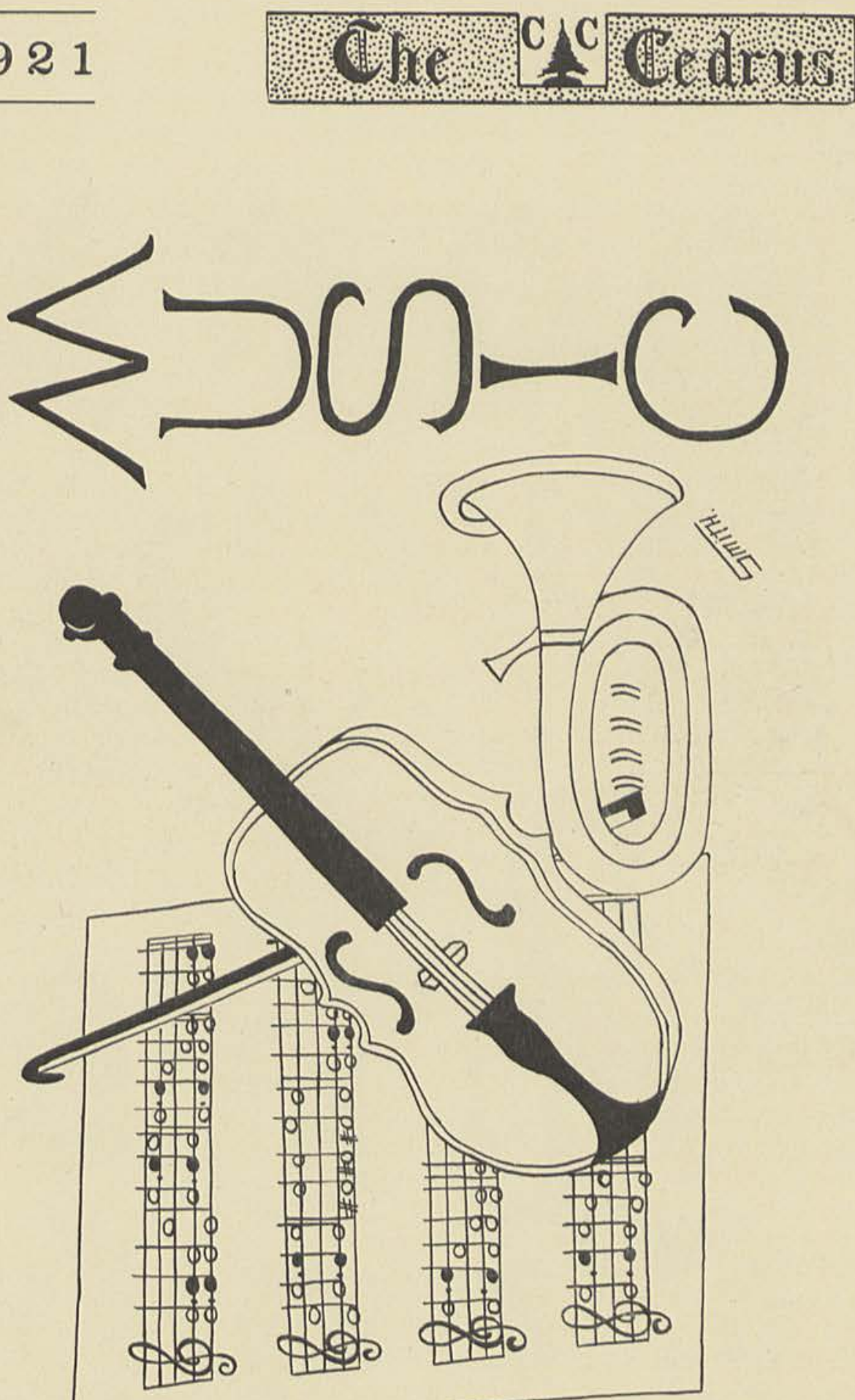


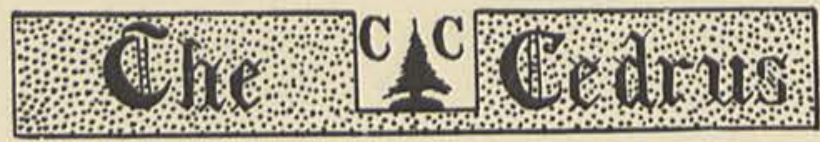

1921

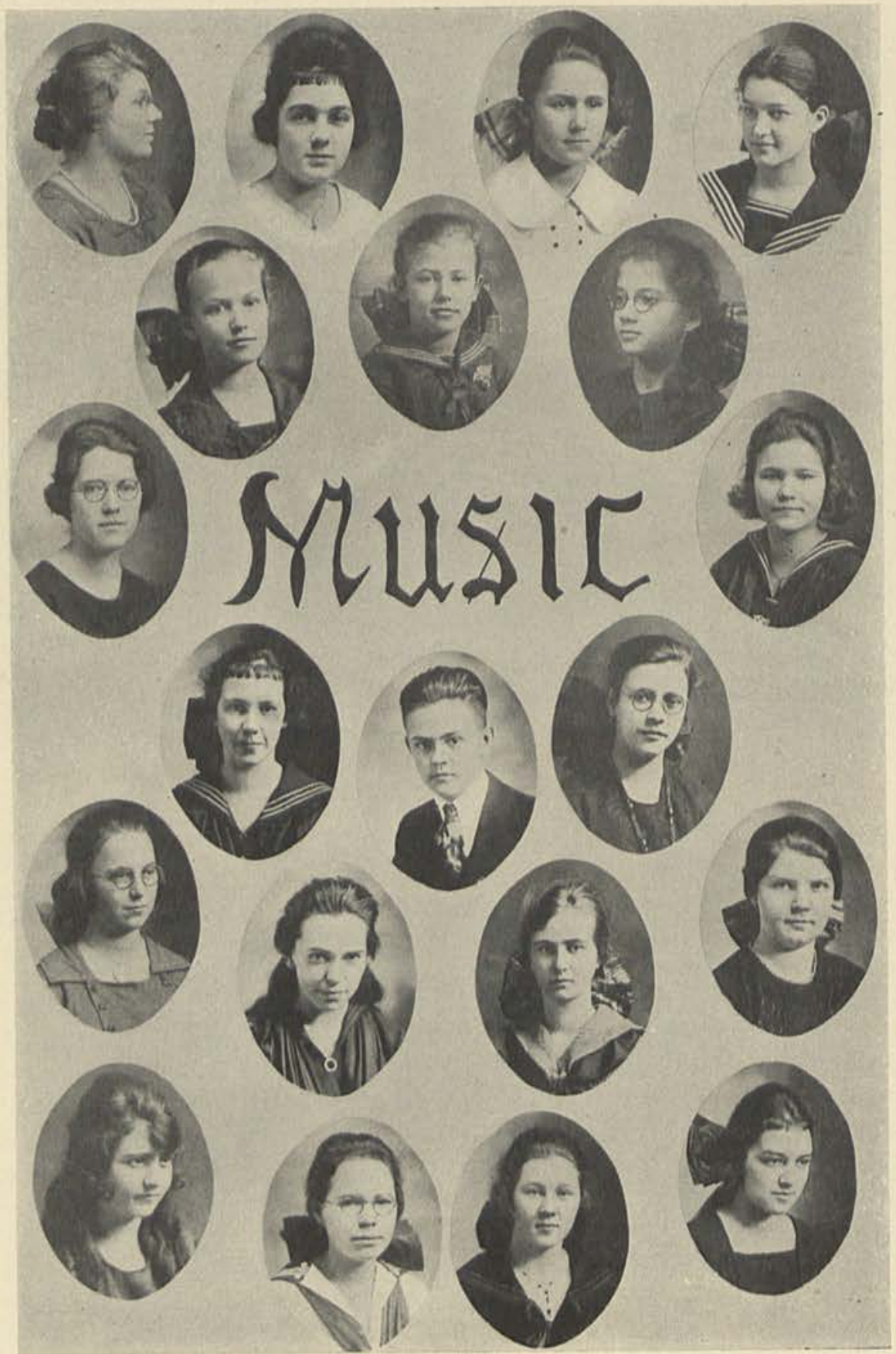




\section{1}
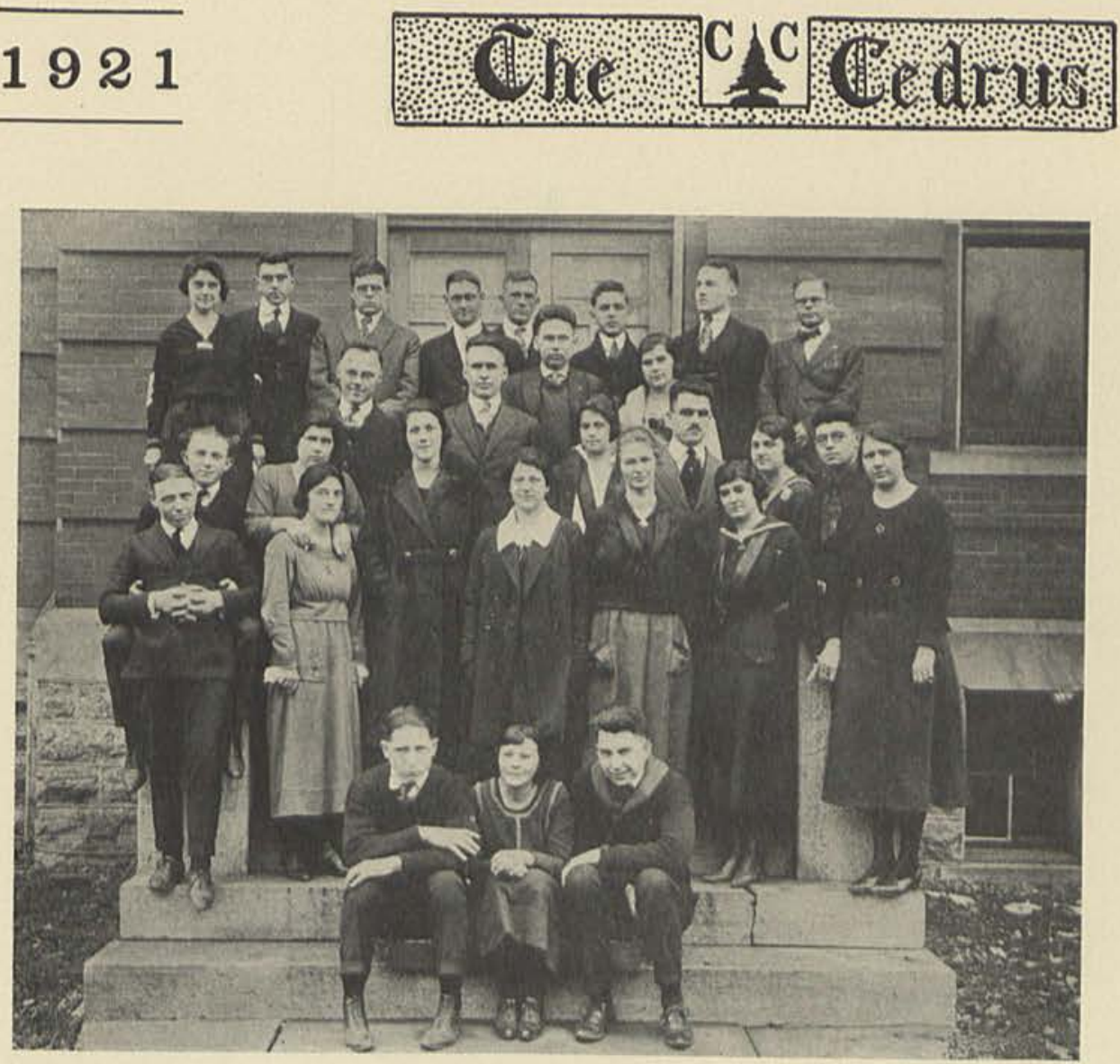

\section{GLEE CLUB}

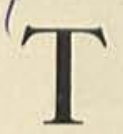

HE Cedarville College Glee Club came into being Thursday evening, October 14, 1920. Miss Mary Goode Royal, of Dayton, Ohio the Professor of Vocal Music in the College, was leader, and Miss Helen Oglesbee was secured as accompanist. A large group of enthusiastic students assembled in Philosophic Hall, and practicing began in earnest. Meetings were held regularly for an hour on Thursday evenings. Part of the time was devoted to separate chorus work and the remainder to the training of the mixed chorus. We made our debut at Ross Township at the Farmers' Institute, Monday, January 24th, when we gave four numbers at the evening meeting. Our singing was compared to that of angel voices, so we know our efforts were appreciated. We had hoped to give a concert this Spring but due to the rush of the Spring semester, it was decided to omit it this year. We hope the Glee Club is not a thing of the past, and that we may have renewed interest and enthusiasm next Fall.)

M. L, H. 


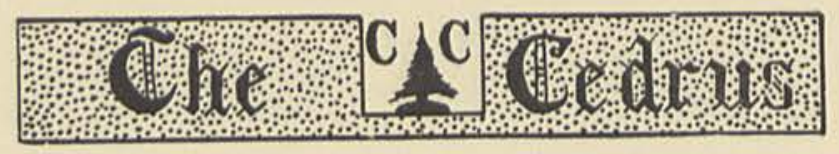

\section{1}

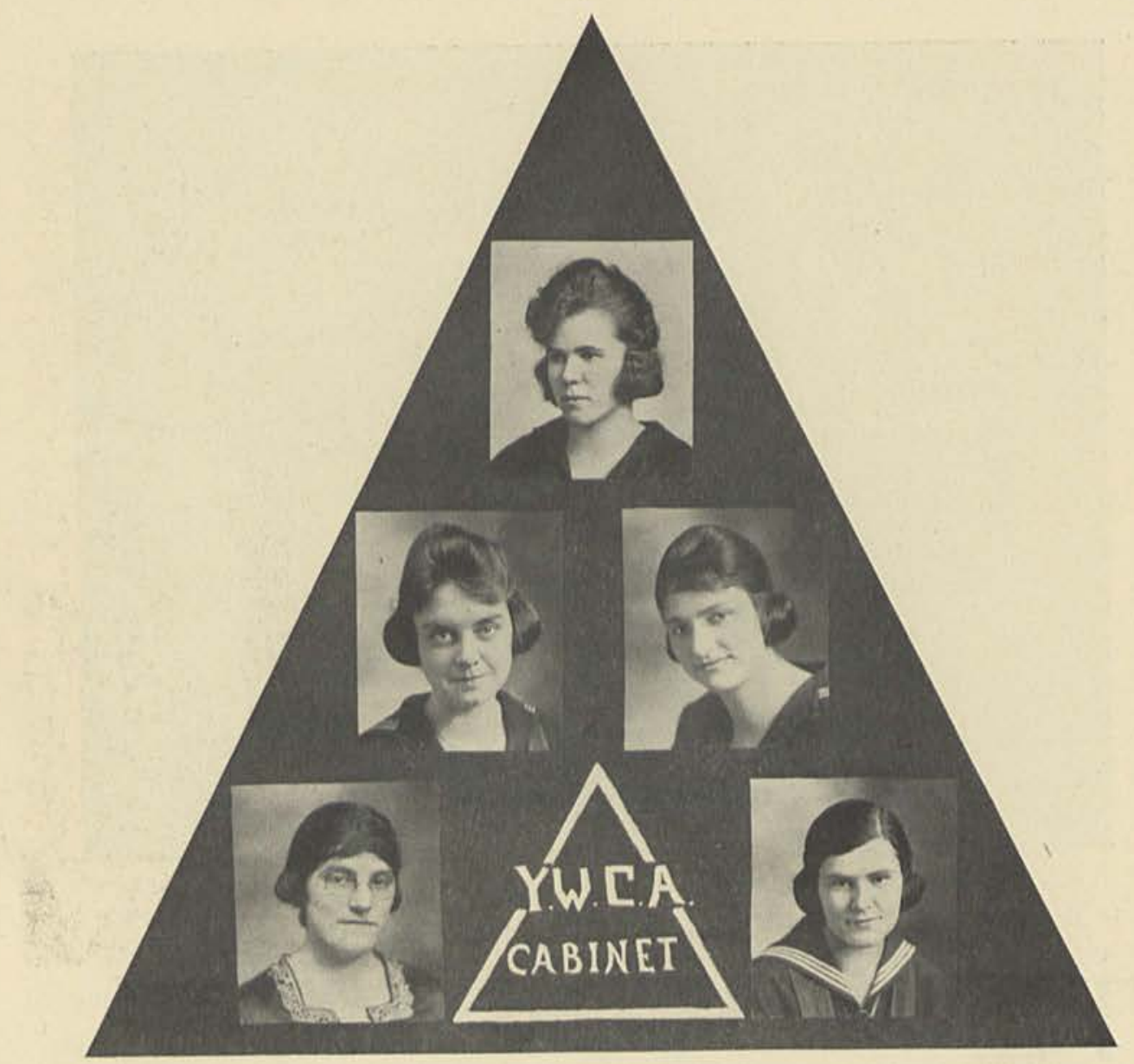

\section{YOUNG WOMENS' CHRISTIAN ASSOCIATION}

7 HE Y. W. C. A. of Cedarville College has enjoyed a large membership this year. Our weekly meetings have been a source of inspiration and pleasure to all of the members. Practically every girl in the college has ably and willingly taken part in these meetings.

(During the last week of February we sent the sum of Ten Dollars to the Chinese Famine Fund. Joint meetings of the Y. M. C. A. and the Y. W. C. A. were held for several weeks during March and April and were addressed by the Rev. J. P. White and Mrs. White. The interest shown by the girls of Cedarville College in spiritual things speaks well for their inner life.)

L. A. D. 


\section{1}
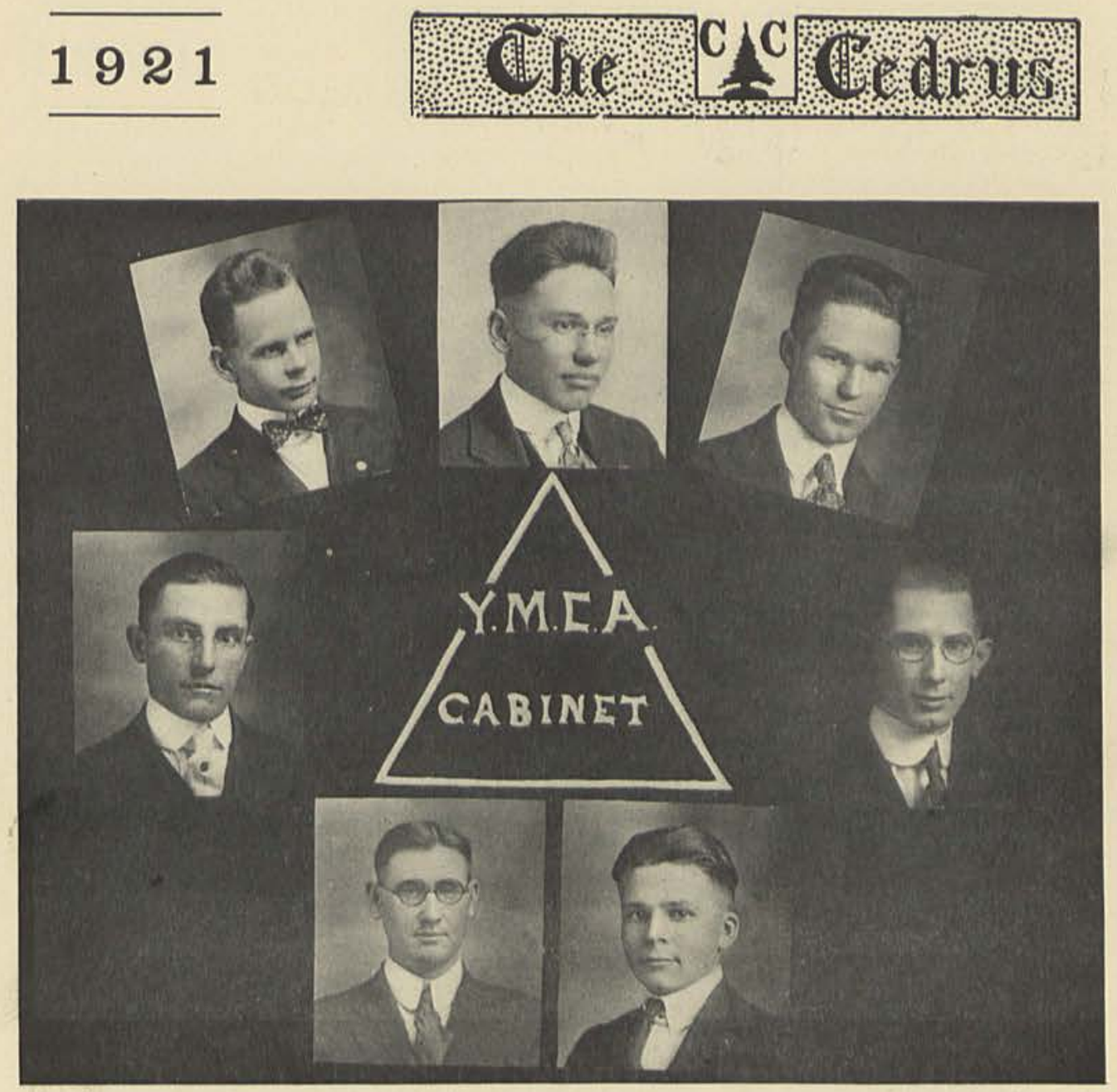

\section{YOUNG MEN'S CHRISTIAN ASSOCIATION}

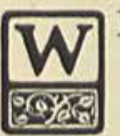

$\mathrm{E}$ feel that the Young Men's Christian Association has meant a great deal to Cedarville College men this year. All the men came back last Fall, deeply interested and the attendance and interest was fine. Toward Spring the attendance began to decrease some but we feel that by every one making himself a missionary along this line that such a thing will never happen again. (After Christmas vacation we divided the Association up into three groups and there was quite a bit of discussion in these groups which was of interest to all present.) These groups were led by Dwight McKune, Wilbur White and Carl Duncan. (At the beginning of the year the Cabinet had Y. M. C. A. membership cards printed and each member was given a card that would entitle him to visitors' privileges in any Y. M. C. A. in the world. Therefore, in summing up, we who have been regular in attendance at the meetings feel that we have been greatly benefitted and have been brought closer to our Lord and Master Jesus Christ.)

The officers for next year are as follows: Edwin Bradfute, President, Charles Townsley, Vice President; Arthur Findley, Secretary; Riley Clarke, Treasurer.

R. W. S. 


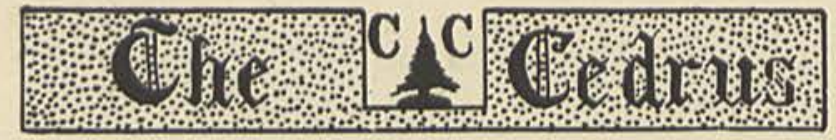

1921

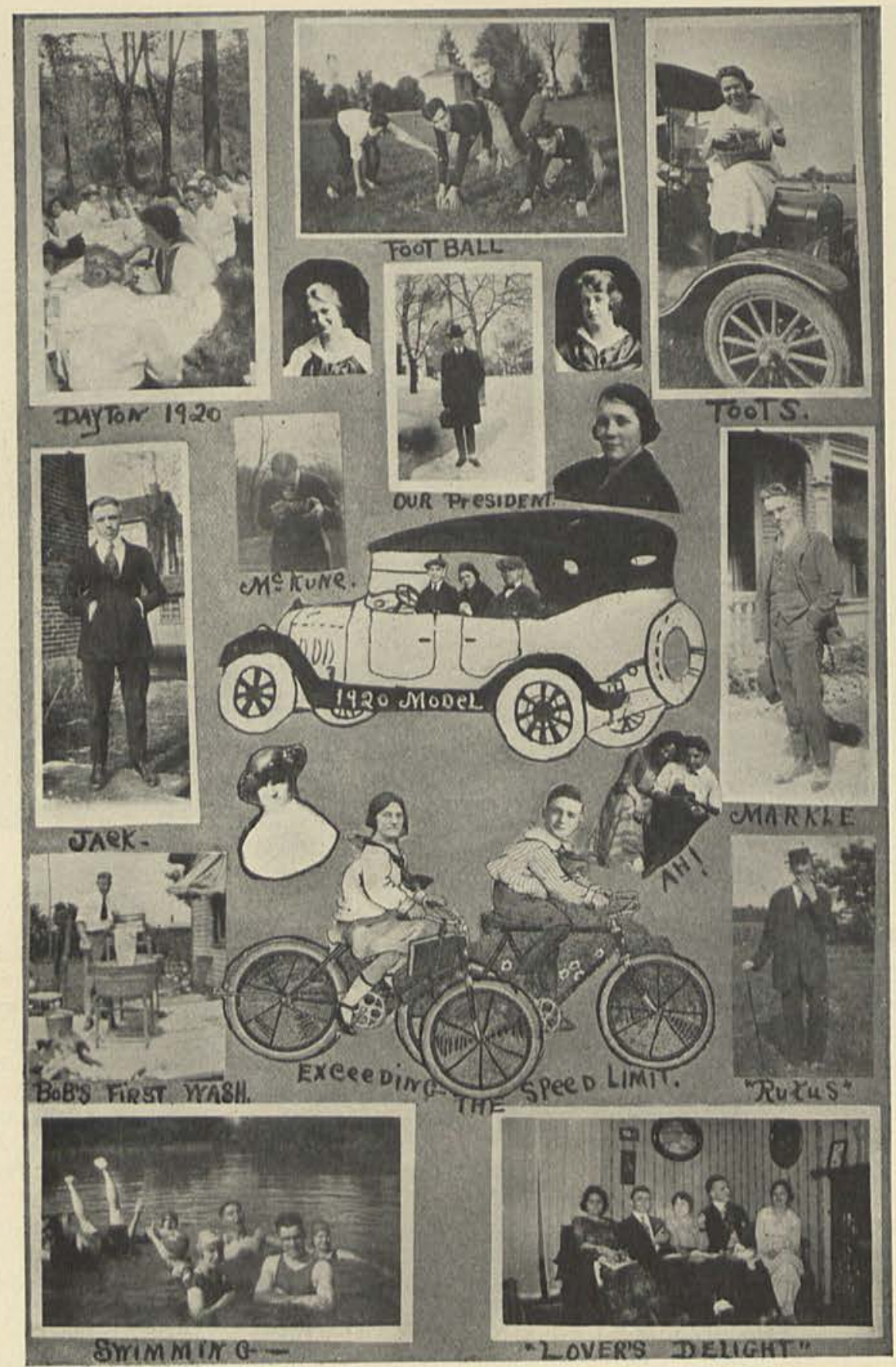


1921
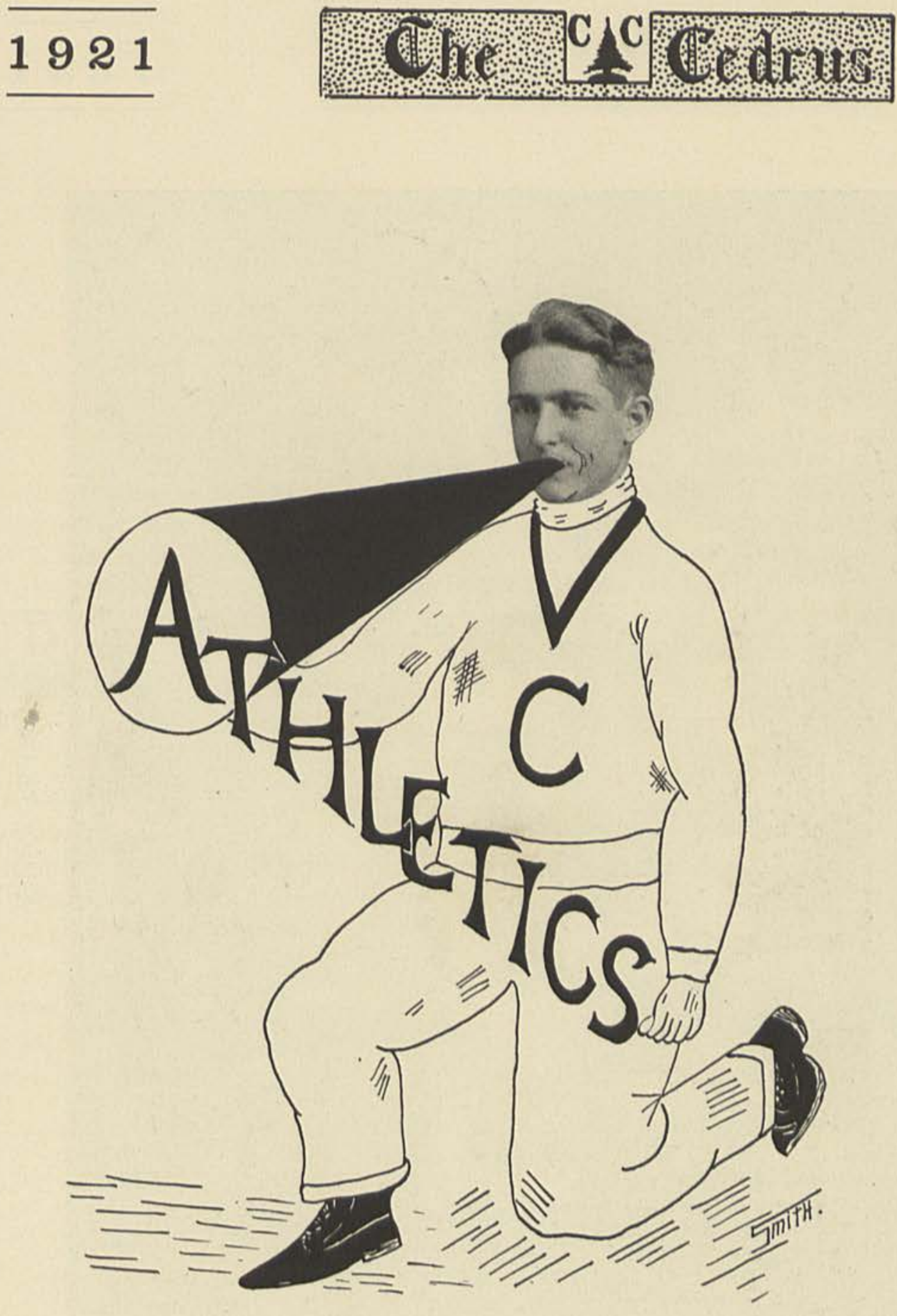

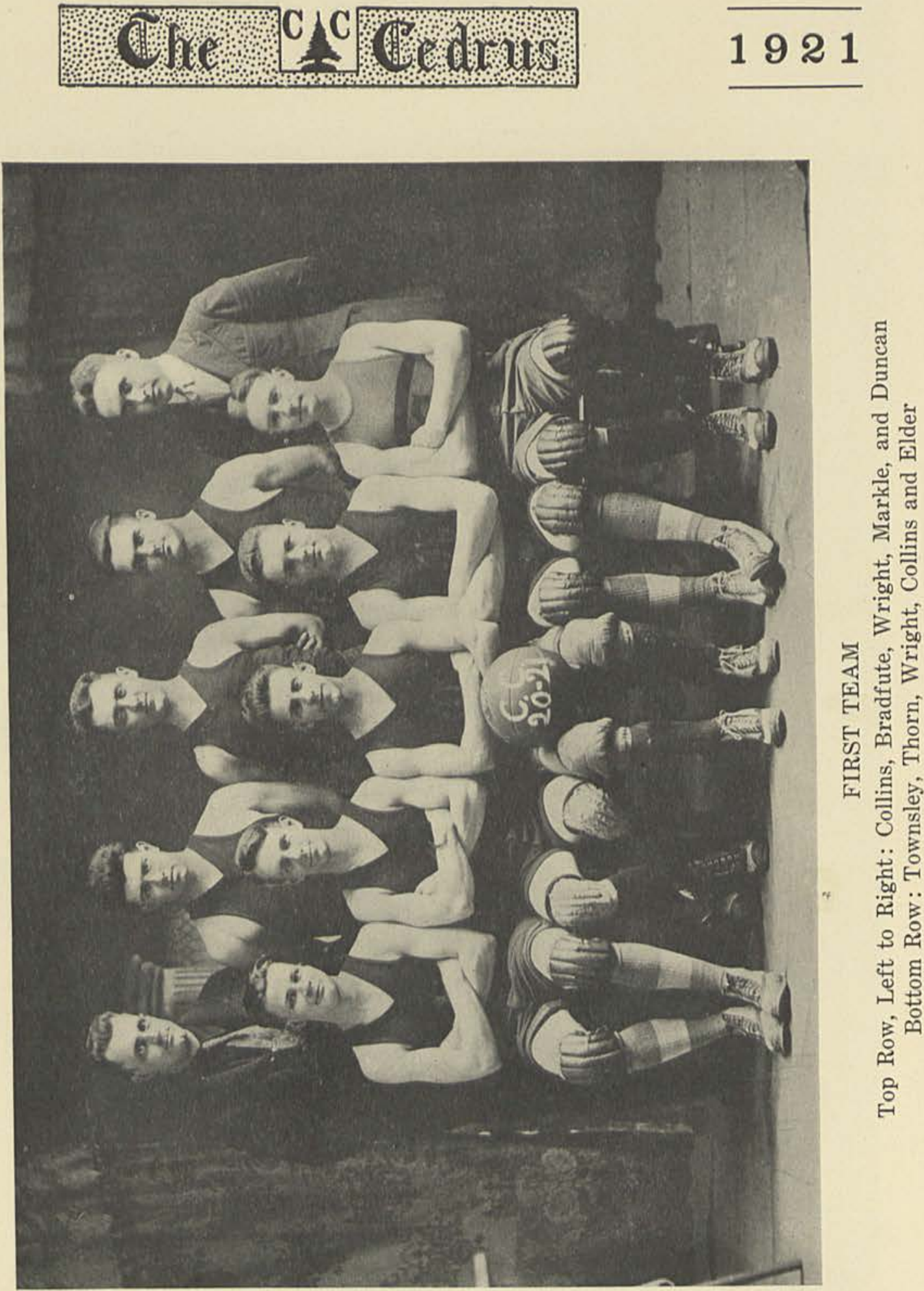


\section{1}

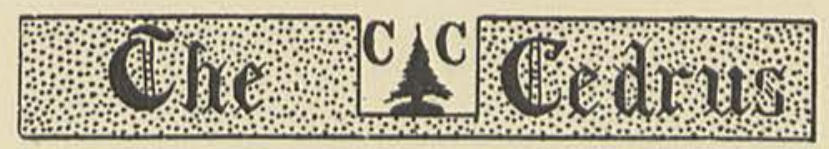

\section{BOYS’ BASKET BALL REVIEW}

URING most of the basketball season the Cedarville team had lots of luck-but it was mostly bad. The fates were against us for although the team played a fast floor game, the shooting was not at all perfect.

The majority of the players were light-weights and this proved quite a handicap when playing some of the heavier teams we met. During the season we played some of the best teams in Southern Ohio. The schedule included Dayton University, Cincinnati University, Muskingum, Marietta, Defiance, Bluffton, Baldwin-Wallace, Bowling Green Normal, Wilmington and Antioch.

At the first of the season the prospects seemed bright for a good team. Four letter men were back and all of last year's second team were here to pick from. A light but fast team was selected but the jinx was with us most of the season.

W. W. W. 


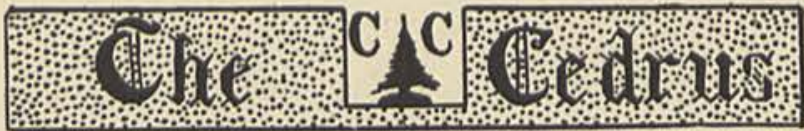

1921

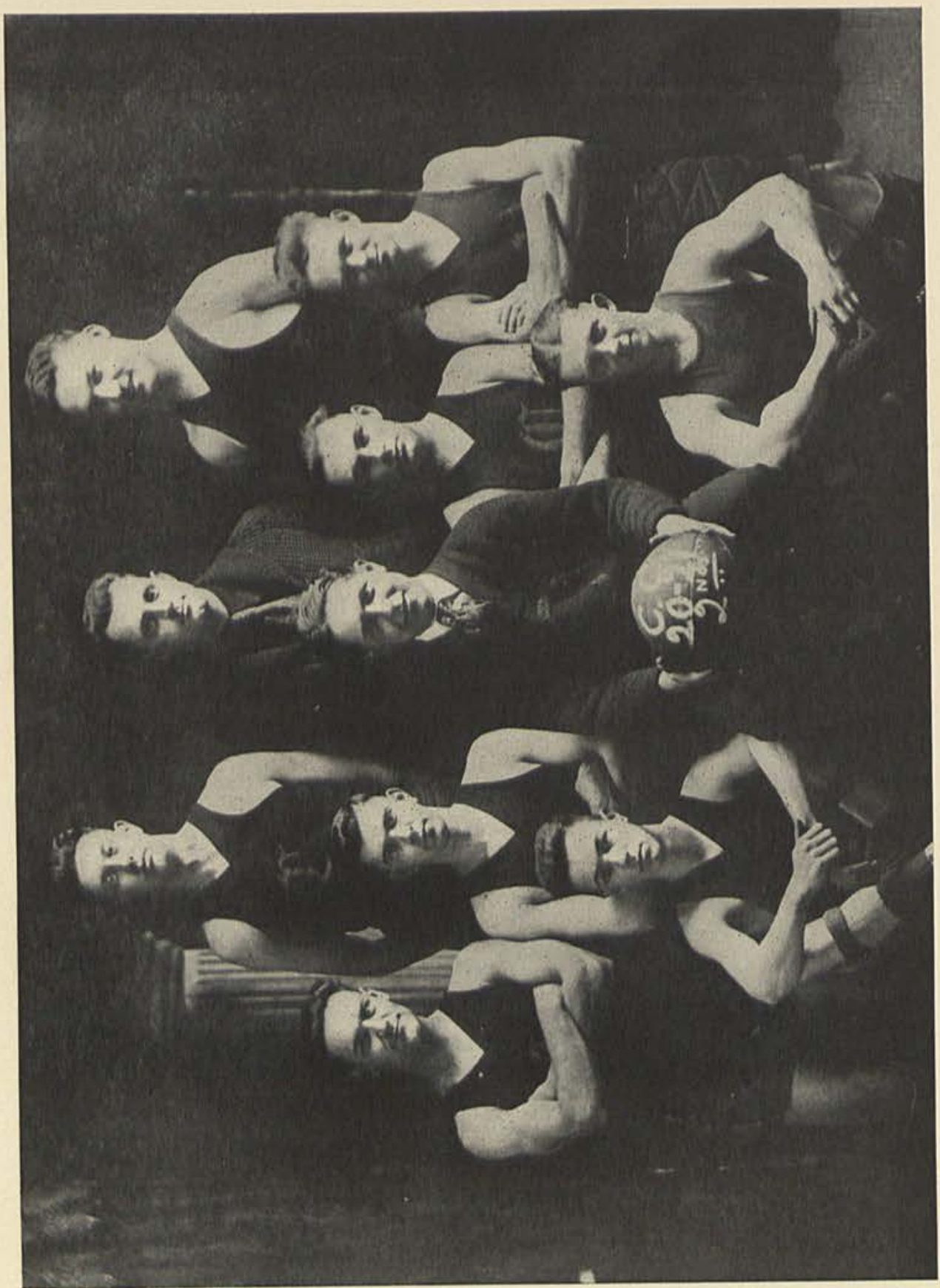

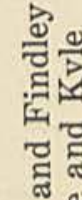

क्ते

寻要

O

४ हี่

되류

동

을

之击焉

نํㅛㅇ

वा

ข

인ㄷㅇ

范舟

ब

올

윤리 

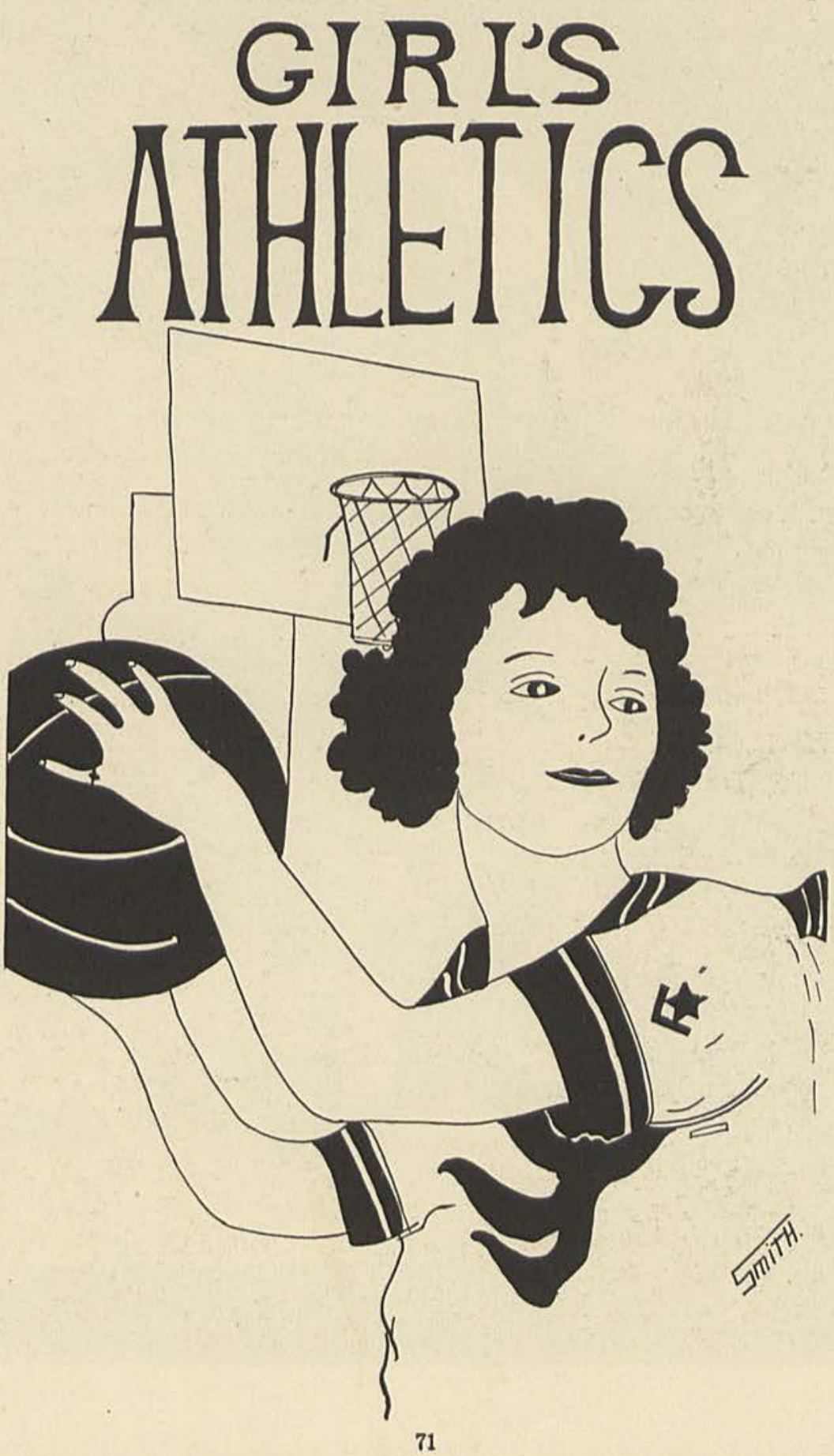


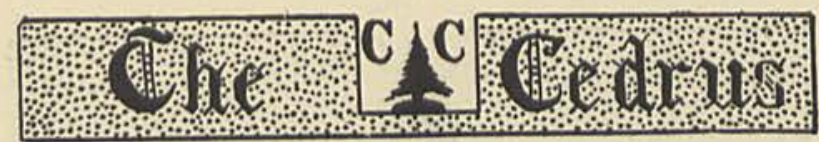

1921

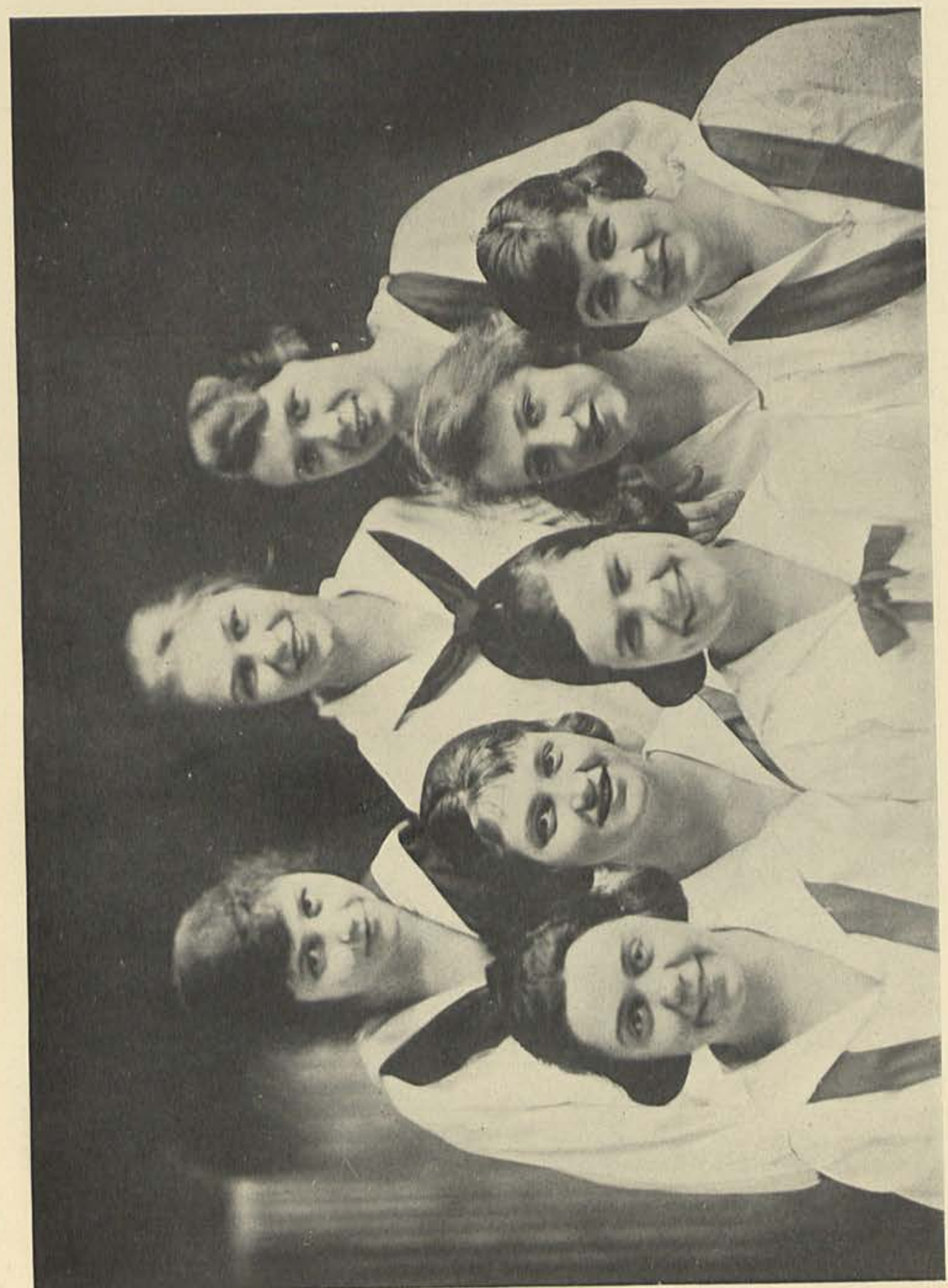

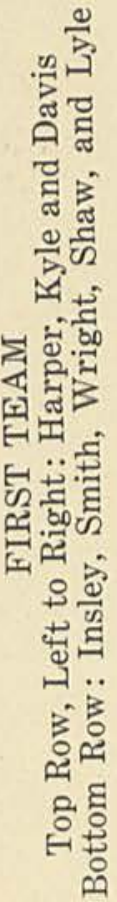




\section{GIRLS' BASKET BALL}

Florence SMith, Captain

Eloise Davis

Christine KYLE

ANNA HARPER

Alice Daines

MARJORIE Wright, Manager

EDARVILLE College has reasons to be proud of her girls' basket ball squad this year. Out of a season of fourteen games they came out victors in ten of these battles. Springfield High and Y. W. C. A. were the only teams that were able to subdue this year's team. The Springfield Y. W. aggregation has played together for five years and it is without a doubt the best of the two squads. The game with the High School was greatly slowed up owing to the fact that our girls had defeated the Quaker Maids the night before by the score of 17 to 7. This accounts for the loss of that game. This is a much better record than the season of '20. Most of this year's team were members of the squad last year so we can be proud of the team that made possible the success of the season just finished.

The trip to Bluffton was by far the most interesting of the season. Ask the girls if they would like to have a- "Ham Sandwich." Bluffton also has the honor of winning from this year's team, by four points. "We are proud of you just the same girls."

Our hopes and prospects for next year's team are very high. This year's squad of all star guards, efficient centers, excelling forwards and "peppy subs" with the prospective candidates will be up and at 'em with oodles of vim, vigor and vitality to produce another state championship sextette. Let us all boost this project and be instrumental in making a Bigger and Better Cedarville College in the near future.

L. $R$. 


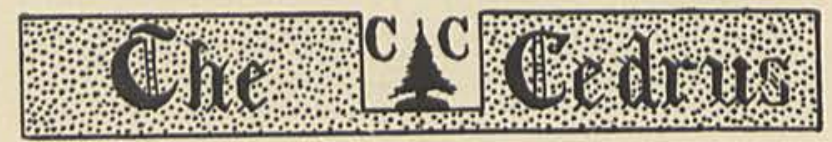

1921

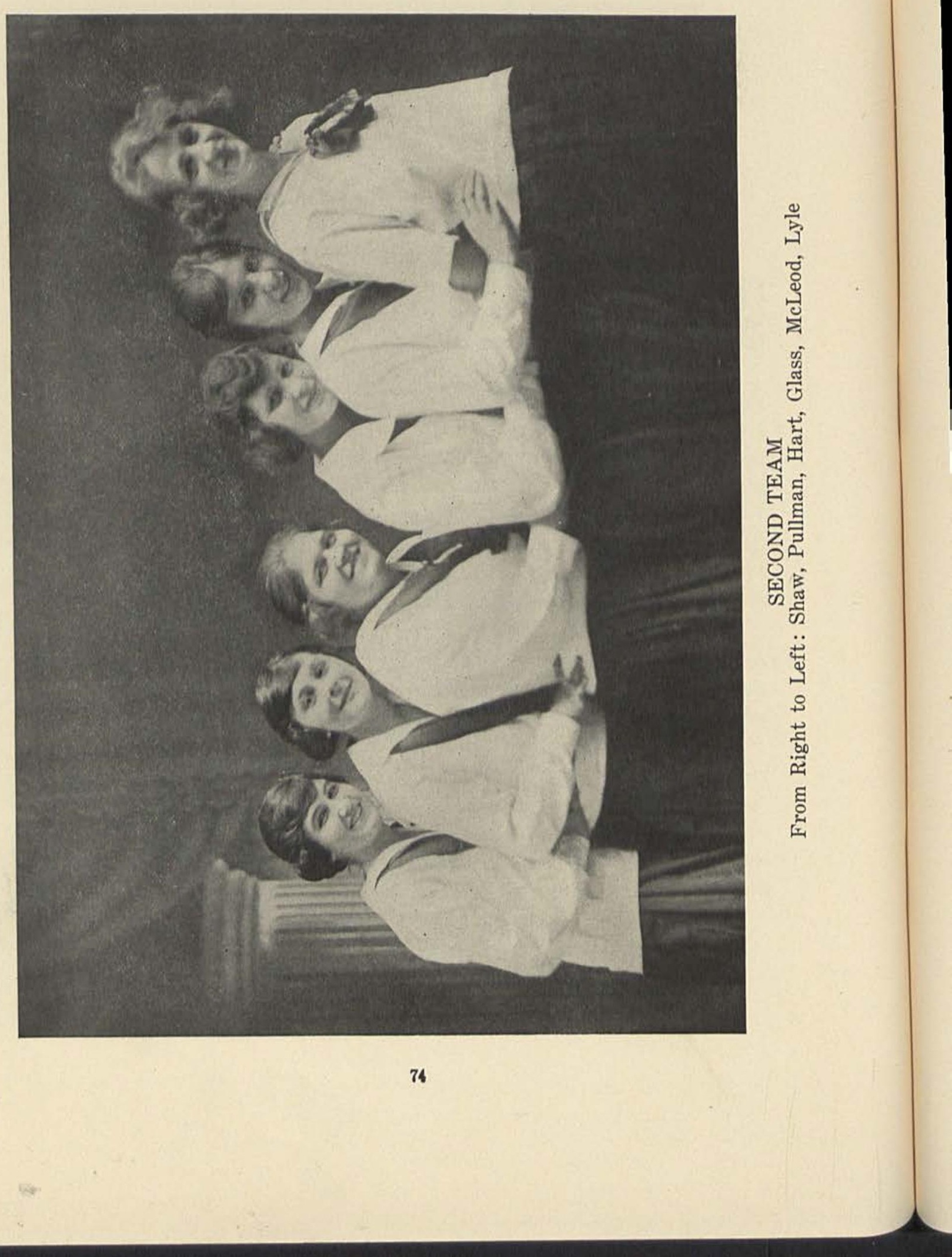




\section{THE STADIA}

OR a College, whose existence covers only twenty-seven years, Cedarville holds an enviable record in Athletics.

Turning back over her history we find that in 1897 her year and for three years she was acknowledged champion in both sports by all of the surrounding Colleges.

Owing to her size it was very difficult for her to send out winning teams but in spite of this she continued to send out football teams until 1911 and baseball has never been taken from her Athletic Calendar.

In 1902 Dr. John Alford presented to the College the old R. P. Church building. This was converted into a gymnasium and the organization of Basketball teams was made possible. Since this time Basketball has been Cedarville's leading sport and many fast teams have represented old C. C. on the floor. Teams from Muskingum, Baldwin-Wallace, Denison University, and Carnegie Tech. have met our teams and found them worthy opponents. The Girls' Team of 1911 were State Champions.

Owing to the War and other unfavorable conditions Cedarville Athletics have taken a slump during the past few years but we have not "given up." No, Sir! Some one has said that "You never do know how hard Cedarville can fight until she's in the last ditch and when you think she has lost she hasn't." We have our plans made for bigger and better Athletics at Cedarville next year. A Football team is assured and the prospects for Basketball and Baseball are bright. No one who is interested in Athletics will make a mistake in coming to Cedarville next year. We are getting set now and next September we are going to GO.

A BOOSTER '23. 

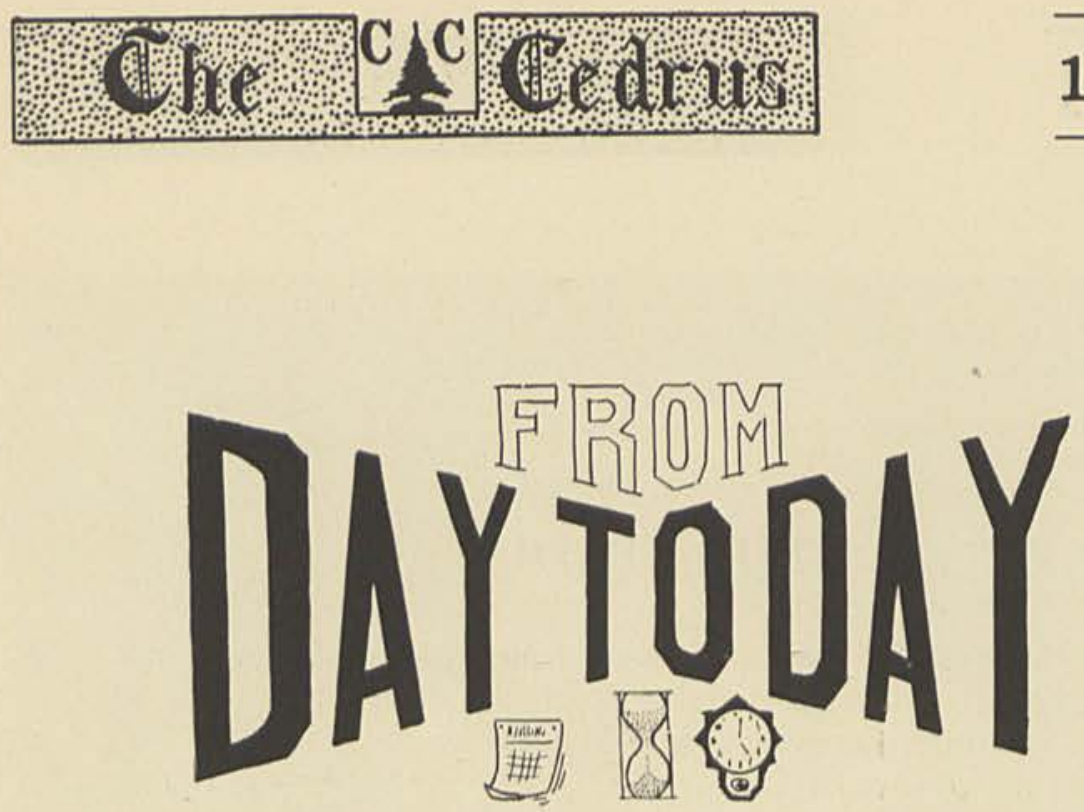

SEPTEMBER 13. Those anxious to begin work arrive in town.

SEPTEMBER 14. Those who were not so anxious arrive just in time, for-

SEPTEMBer 15. School began. Address by Rev. Foster.

SEPTEMBER 16. "Oh, those classes."

SEPTEMBer 17. C. E. reception at the R. P. Church. Yes, we got acquainted and also learned some valuable dope on beauty hints.

SEPTEMBER 20. Talks of having spreads.

SEPTEMBER 21. It really happened. The Juniors had a spread. Just the Juniors, you say? No, the Sophomores did too and many gladly received the rinds from the watermelons.

SEPTEMBER 22. Gentle hints by the Prof's to "cut out spreads during the week."

SEPTEMBER 23. Close watch on the Freshies. Many thought they were going to break loose.

SEPTEMBER 24. Freshies really had a "2 minute" meeting to get acquainted. Epworth League entertained the college students. Some time we had, too. But afterwards! Ask Clarke and Brown about that!

SEPTEMBER 25. Who stacked the rooms?

SEPTEMBER 27. The thoughts of the Sophomores: "The Freshman never will have a spread."

SEPTEMBER 28. Soph's never do study. Another spread.

SEPTEMBER 30 . And-the Freshies had a spread.

OстовеR 1. Chicken feed at the Gym but several Freshies could not stand two nights in succession.

OCTOBER 5. First meeting of the Foreign Mission Study Class. The attendance was fine.

OCTовеR 8. Did you say spreads? Juniors and Seniors had some spread. Freshies and Soph's made a visit to the grave yard.

OстовеR 11. First meeting of Orange and Blue. Splendid attendance and program.

OCTOBER 12. The girls had some spread at Ramsey's and then-kimono parade.

OCTOBER 13. Iron rule of the Seniors teaching.

OCTOBER 14. Glee Club practice.

OCTOBER 15. Boys' spread at Cooper's but do you know our Science teacher seems to have been present? How strange!

OстовеR 19. "The Climax Company" as the first Lecture Course number. There was a fine attendance even if some did go to the wedding. Whose? Why, James Chestnut's.

Octoвer 20. Yes, the Freshmen had a spread. Why didn't we chase them? Really we didn't have time, a good reason.

OCтовеR 22. Sophomore spread. They have nothing else to do. Bible Reading contest tonight with thirteen contestants. Results: McKune, first; C. Duncan, second; Markle, third. 
ОстовеR 23. History class worked on notebooks almost all day.

OCTOBER 25. Too busy for comfort.

OCTOBER 26. Yes, we had play practice.

OCTOBER 28. Continual fear of tests and some fear was not in vain. Miss Klenk talked to students in Chapel.

OCTOBER 29. Annual Hallowe'en party with girls as hostesses. Enioyable event.

NOVEMBER 1. Literary and then-oyster feed at Margaret MeCarty's.

NOvember 2. Cedarville College girls cast their first vote.

NOVEMBER 3. Hurrah for Harding!

NOVEmber 4. Prof. Johnson of Case University spoke in Chapel.

NOVEmBER 7. College Night. Dr. McChesney preached; music by the College.

NOVEMBer 8. We endure the iron rule of classmates during Miss Brand's absence.

November 9. Nel and Helen arrive on the scene, or rather Mr. \& Mrs. Thorn. Bob Colman was given a free buggy ride and we got a treat.

NOVEmber 10. Freshies take all night for a spread!

Novemper 11. Armistice Day. Jun'or-Seninr spread. Party at Smith's.

November 12. Y. P. C. U. entertain the College. Swell time.

November 19. Cedarville found out what happened to Jones. Feed at Smith's.

NOVEMBER 22. Thanksgiving program in Literarv society.

NOVEMPER 23. The theatrical troune plaved for Ross Township audience.

NovEMPER 24. The Spring Vallev folks found out what happened to Jones.

NOVEMBER 29. We enioved Thanksgiving Dav but where did vacation go?

DECEMfER 1. Rev. Mr. Nash begins Evangelistic campaign.

DECEMBER 8. First Basket Ball game of season at Washington Court House.

December 10. Cedarville College brys v Rival B. B. Team, and girls played the Y. W. team from Springfield. The biggest crowd ever!!

DECEMBER 13 and 14 . Tests galore.

TANUARY 4. Vacation of three weeks ended today.

IANUARY 5. Classes again. Louisa hasn't much to say about Xmas gifts!

TANUARY 8. Antioch oame with Junior-Senior feed afterwards.

JANUARY 9. College night at the Methodist Church. McKune preached.

JANUARY 11. Boys left on four day Basket Ball trip.

JANUARY 12. Turkat's History tests begin. How long will they last?

JANUARY 13. Prof. Hathaway reproved at flee Club practice!! The quartet made a great imnression at the W. C. T. U. meeting.

IANUARY 17. Another week of tests, a seeming necessary evil.

JANUARY 18. Freshies fed B. B. fans after Waynesville and Beaver games,

JANUARY 21. French test!! Oh! horrors!

IANuARY 23. The noted Psychologist, Dr. McKeever, speaks in Cedarville.

JANUARY 24. The Glee Club entertained at Ross Twp. High School at the Farmer's Institute. They enioyed the feed afterwards.

JANUARY 25. Faculty attempts fastine but it doesn't work. The very interesting, scientific lecture of Montraville Wood tonight.

JANUARY 28. Mr. Fillmore and Prof. Allen speak in Chapel, the latter asking for volunteers.

FEBRUARY 3. The semester closed, to the delight of many.

FEBruary 7. Bolshevist banquet at Wright's but Anti's get the ice cream. Hammond got a free ride and George Moore got a $c a n$.

FEbruary 8. Opening address of second semester by Rev. Scott.

FERRARY 11. Dr. and Mrs. McChesney entertain, and say, we had a fine time.

FEBRUARY 13. Gavin Reilly preached and College Quartet sang.

FEBruary 14. Rev, Mr. VanKirk exhibited "Wrorld Peace Flag" in Chapel.

FERRUARY 15. Athletic Banquet at R. P. Church. Hammond enioved one reading.

February 16. Miss Brand returns to her duties and all are thankful.

FEBRUARY 17. Rev. Mr. Rife gave a splendid message in Chapel.

February 18. Day of Praver for Colleges. Rev. Harriman preached.

February 22. Washington's Birthday. Mobley's lecture at Opera House.

MARCH 4. Inauguration of President Warren G. Harding. Cedarville B. B. Teams won two games in one evening.

MARCH 11. Cedrus closed to send to printer, Amen! and Amen! M. M. P. 


\section{1}

\section{IN MEMORIAM}

Again death has broken the ranks of the graduates. Joseph Raymond Fitzpatrick, of the Class of 1904, after a lingering and severe illness passed away last Fall, at his father's residence, near Xenia, Ohio. Mr. Fitzpatrick entered Cedarville College from the public schools of Silvercreek township in September, 1898, and graduated with the degree of A. B. in June, 1904. He served as professor of Mathematics and Science in Cedarville College for five years. He received the degree of A. M. in 1907. He did post-graduate work in Ohio State University and in the State University of Pennsylvania. At the time of his death, he was instructor in Chemistry in the latter institution, in which capacity he had served several years. Mr. Fitzpatrick was genial in disposition, thorough in study, faithful in his work, efficient and inspiring as a teacher, beloved and respected by all who knew him. The educational world has lost in his death an able, scholarly and refined gentleman. 


\section{1}

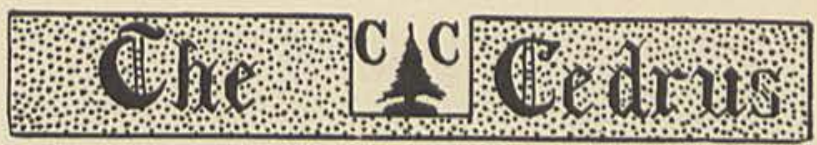

\section{TRULY EDUCATED}

A Professor of the University of Chicago told his pupils that he should consider them educated, in the best sense of the word, when they could say yes to every one of fourteen questions on a list which he presented to them to answer. The list is as follows:

Has your education given sympathy with all good causes and made you espouse them?

Has it made you public-spirited?

Has it made you a brother to the weak?

Have you learned how to make friends and keep them?

Do you know what it is to be a friend yourself?

Can you look an honest man or a pure woman straight in the eye?

Do you see anything to love in a little child?

Will a lonely dog follow you in the street?

Can you be high-minded and hapny in the meaner drudgeries of life?

Do you think washing dishes and hoeing corn just as compatible with high thinking as piano-playing or golf?

Are you good for anything to yourself?

Can you be happy alone?

Can you look into a mud-puddle by the wayside and see anything in the puddle but mud?-Selected.

\section{STATEMENT}

In response to the incessant demand to ascertain whither all the money which has passed through my hands goes, I make the following statement:

ASSETS

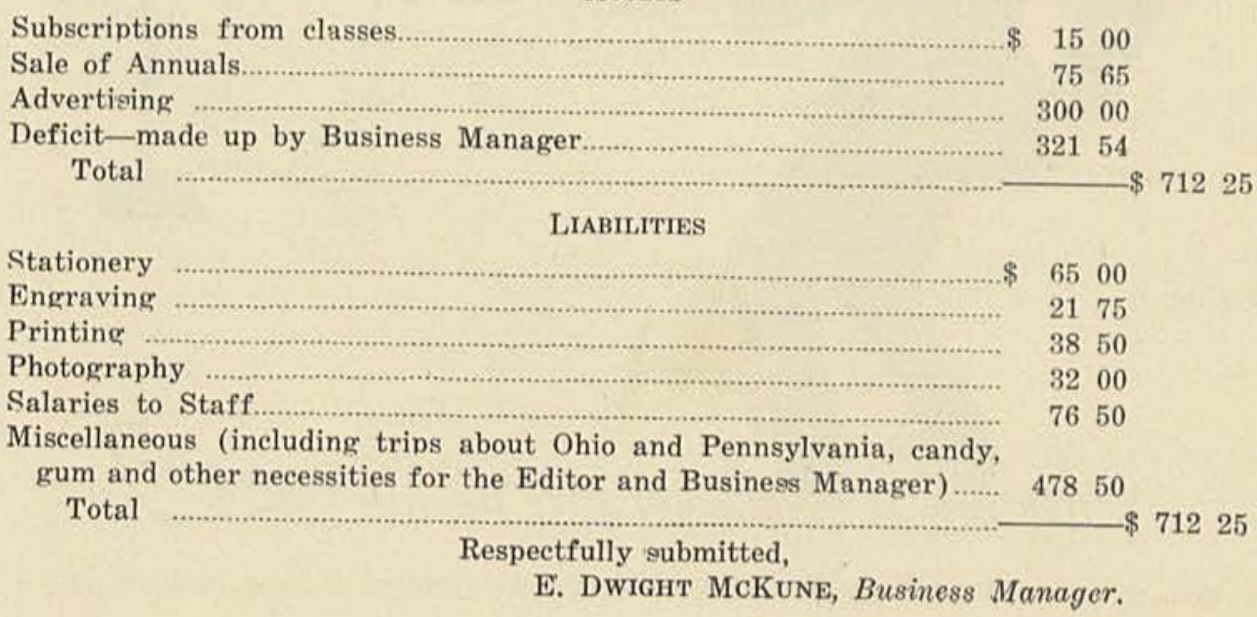




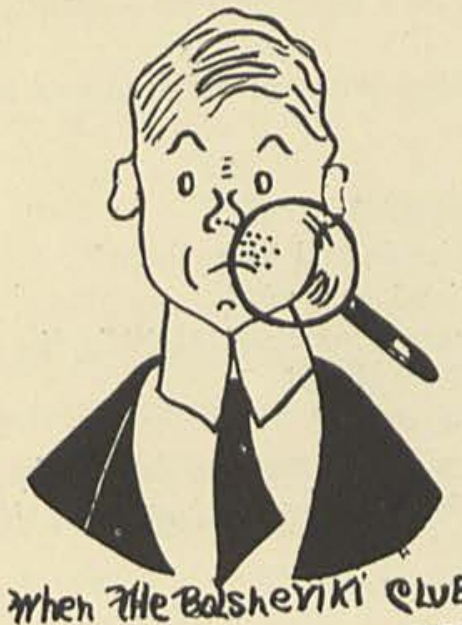

THEY TAKE THEIR HAIR-CUTS Very Peacejully.

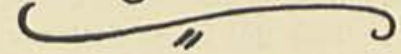
WAS AT ITS HEIGHT.
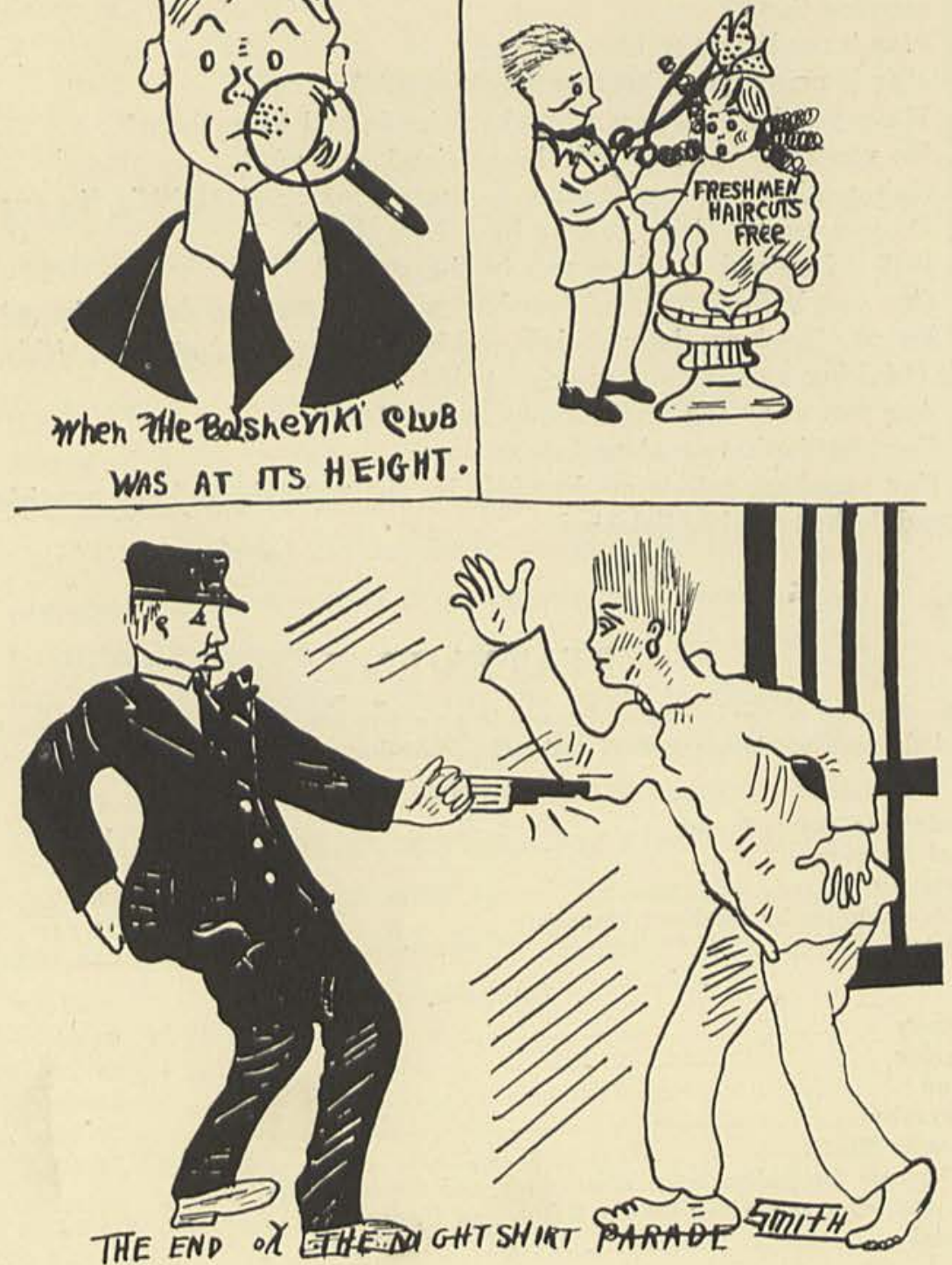


\section{1}
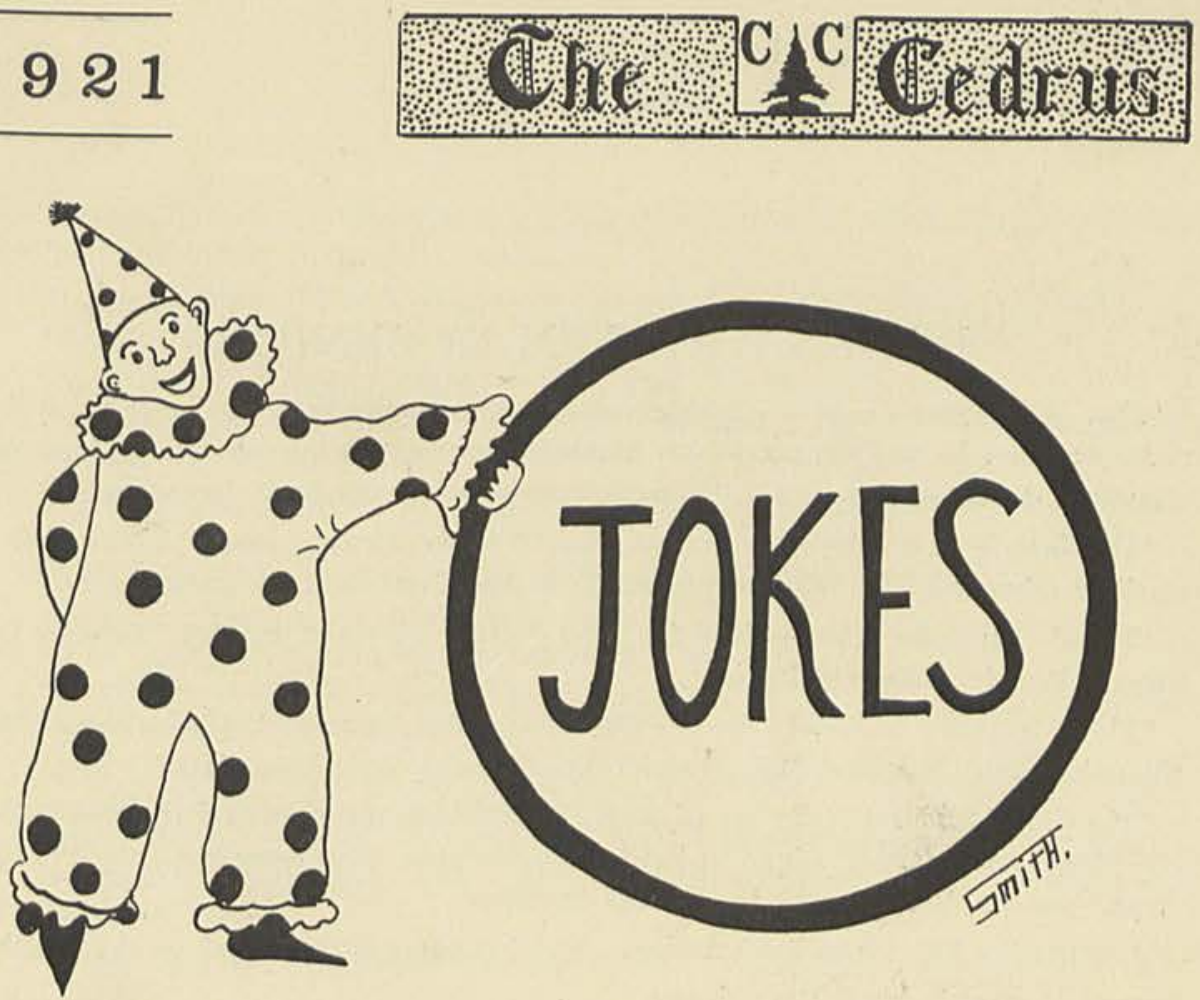

Prof. Brand: "Next semester I am going to require all back work to be in one week ahead of time." Editor's Note: "Traveling some."

Anderson: "If it takes seven days to make one week, how long will it take to make one strong?"

Edith (rather bored and sleepy at 1:30 a. m.) : "I don't know a thing about Base Ball."

Carl: "Let me explain it to you."

Edith: "Very well, give me an illustration of a home run."

They were wandering through the apple orchard on a breezy moonlight night.

Grace: "Oh, Edwin, hear the trees moan and sigh?"

Edwin: "I guess, dear, if you were as full of green apples as the trees are, you'd moan and sigh, too."

Miss Greer (in Biology Class) : "What do bees do with their honey?"

Colman: "They cell it."

A telegram delivery boy knocked at the door of a certain Freshman's house about $1: 30$ a. m., calling: "Is this where Clarke lives?" Lucinda, answering: "Yea, bring him in."

Ashbrook: "Gee, I had a funny dream last night."

H. Wright: "I know, I saw you with her."

English Professor (explaining difficult scenes from Macbeth) : "Now, class, if you had this in your head, you would have it in a nut shell."

West Point Official: "Have you had any military experience?"

Moore: "Yes, indeed. I have worn a wrist watch for years." 


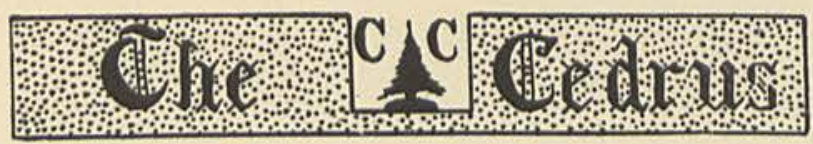

\section{1}

\section{BOOKS WRITTEN BY SENIORS}

"How It Happened"-In his latest book the author tells in a fascinating and dramatic way how he won the girl of his heart. This complete tale abounds in humorous situations, touching scenes, and telling occurrences. Leslie Scott Dean, author.

"The Leap"-Ten volumes. Author, Paul Warren Duncan, says: "I was once as small as other men. In my new booklet I tell how I attained my great height."

"Would You Grow Thin"-Send for Miss Stewart's booklet entitled "How to Lose Twenty Pounds in Twenty Days."

"The Infatuation of Swisı Cheese"-By Millie Parker, humorist, and author of "The Nourishment of Doughnut Holes," and "Why Bachelor Girls Keep Cats."

"The Cry of Children"-By one of them. In this book the recently-discovered authoress, Miss Louisa Greer, brings to light some startling facts concerning the "Faculty Trust" and its dealings with the College Students.

A TOAST: "Here's to Prof. Jurkat. May his years be measured by the length of lessons he gives in his History classes."

Chemistry Lab. Exp. No. 1.

Apparatus-Three boys.

Enter-Two girls.

Result-Three boys turn to rubber.

Stewart (applying for a job) : "What's the chance for a fellow beginning at the bottom and working up?"

Foreman: "None; our job is digging holes."

RENOWNED MEMBERS OF OUR COLLEGE

Bum

Jack Ewbank

Operatic Star

Louisa Greer

Tragedian.

Charles Brown

Comedian

Dick Elder

Character Actor

Marjorie McClellan

Joke

Johnny Waite

Good Sport.

Earl Collins

Masher.

Arthur W. Findley

Vamp

Charlotte McLeod

Rube

Ernest Wright

Bill Hart

G. L. Markle

The Terror

Gavin Reilly

Nobody's Baby

Carl Duncan 
Nelson Thorn: "Surely it's a funny thing that when Cupid hits his mark, he generally Mrs. it."

Helen Davis: "Don't you ever eat your corn off the cob, Olis?"

Olis Hart: "Not this Fall. It butters up my ear puffs so."

Cecil Rife: "Hey, I found a nickel in the hash."

Paul Duncan: "Then henceforth hereafter close your head about not finding no change in the feed here."

Miss Weller: "Why are the muscles in my head smaller than those in my arm?"

Miss Deacon: "Because you don't use them so much."

"Is diss a fire insurance office?"

"Yes, sir; can we write you some insurance?"

"Berhaps you can. You see, mine poss dreadens to fire me next Saturday and I like to get some brotection."

Miss Glass: "So you really think your memory is improving under treatment? You remember things now?"

Miss Smith: "Well, not exactly, but I have progressed so far that I can frequently remember that I have forgotten something if I could remember what it is."

Ernest Wright (upon Curtis' arrival) : “Fellows, I can tell you how to get rich."

"How?"

Ernest: "Buy Curtis for what he is worth and sell him for what he thinks he is worth."

James Kyle: "I hear you are engaged to that young widow who is viisting relatives here. Is it true?"

Harold Myers: "Yes."

James Kyle: "How did you discover that she was the only woman in the world for an old bachelor like you?"

Harold Myers: "Why, she-er-told me so."

She was

A beautiful

Girl-and through

The dull light he

Saw she was very

Beautiful-in fact, so

Beautiful that his

Attention was all hers.

She was sitting next to

Him and finally she opened

Those small lips and

Said. "Kiss me, Henry"-

But his name was

George and she

Was reading the

Title off the

Screen to her

Mother!

$\mathrm{Oh}$ ! My!

\section{Oily to bed}

And oily to rise,

Is the fate of a man

When an auto he buys.

"Love is like an onion;

We taste it with delight,

But when it's gone, we wonder

What ever made us bite." -Lehigh Burr.

"On the mule we find

Two legs behind

And two we find before.

We tickle behind

Before we find

What the two behind before."

-Pelican. 


\section{BUY, Don't Borrow From Your Friends}

The friends of our College, whose names and messages appear on this and the following pages, are deserving of the most hearty and loyal support of all who read this College Annual.

Without their aid it would have been practically impossible to have published this year book and we wish to give the honor to whom the honor is due. THE STAFF.

\section{J. VICTOR TARR, AR'TIST}

\section{THE GOLLEGE PHOTOGRAPHER}

"We make the homely pretty, and the pretty beautiful"

\section{The Exchange Bank}

Cedarville, Ohio

\section{DR. O. P. ELIAS, DENTIST}

Phone 87

New Exchange Bank Bldg.

Cedarville, Ohio

$$
\begin{aligned}
& \text { THE CEDARVILLE HERALD } \\
& \text { Established } 1878
\end{aligned}
$$

\section{E. MASTERS}

\section{GROCERYMAN}




\section{1}
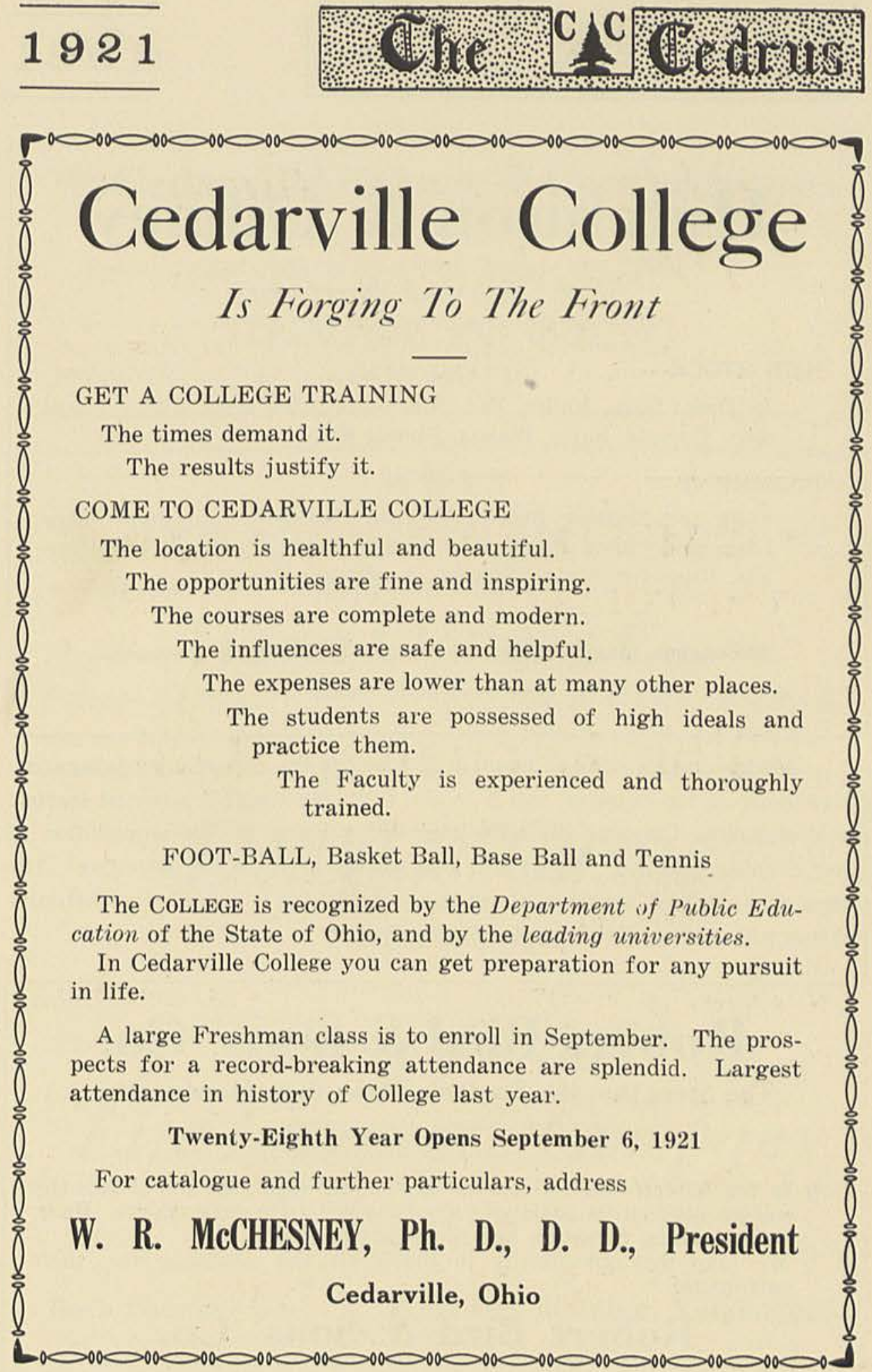


\section{Hutchison \& Gibney}

\section{8th Year of Bargains}

\section{NEW STOCK-}

In Dress Silks, Voiles, Etc., Sheetings, Ginghams, Pillow Cases, Etc., Corsets, Suits, Waists, Skirts, Etc.

\section{BASEMENT-}

Cook and Heating Stoves, Kitchen Cabinets, Aluminum Ware, Glass and China, House Furnishings, Trunks, and Kitchen Utensils, Rugs for Parlor, Sitting and Dining Room.

Thank our many customers for the 1920 Year's Businessthe best in 58 years

Always have a book at hand, and, whether the opportunity brings you two hours or ten minutes, use it to the full. An English scientist learned a language in the time his wife kept him waiting for the completion of her evening toilettes. Every life has pauses between its activities. The time spent in local travel in street cars and ferries is a golden opportunity if one will only resolutely make the most of it.

\section{Robert Bird \& Sons' Co.}

\section{The Store that the Students Make their Headquarters}

$$
\text { We Try To Please Them }
$$

II In our Young Men's Department you will find just the things the college student is looking for: Snappy, up-to-date Shirts, Hose, Collars, Hats, Sweaters and Shoes at the right prices.

If We take this opportunity to thank all the students for their patronage.

\section{Robert Bird \& Sons' Co.}




\section{The Cedarville Bakery \& Confectionery}

Fine Baked Goods and Confections

Special Prices Given to Churches, Lodges and Those Who Buy

in Quantities

"CLEANLINESS AND QUALITY"

Phone 86

OUR MOTTO

\section{WHY?}

WHY can we give U BETTER VALUES in CLOTHING, HATS, FURNISHING GOODS \& SHOES than The BIG CITY STORES? - - On account of our LOW OVERHEAD EXPENSE. TRY US.

\section{Home Clothing Co.}

"Trade At Home"

G. H. HARTMAN, Prop.

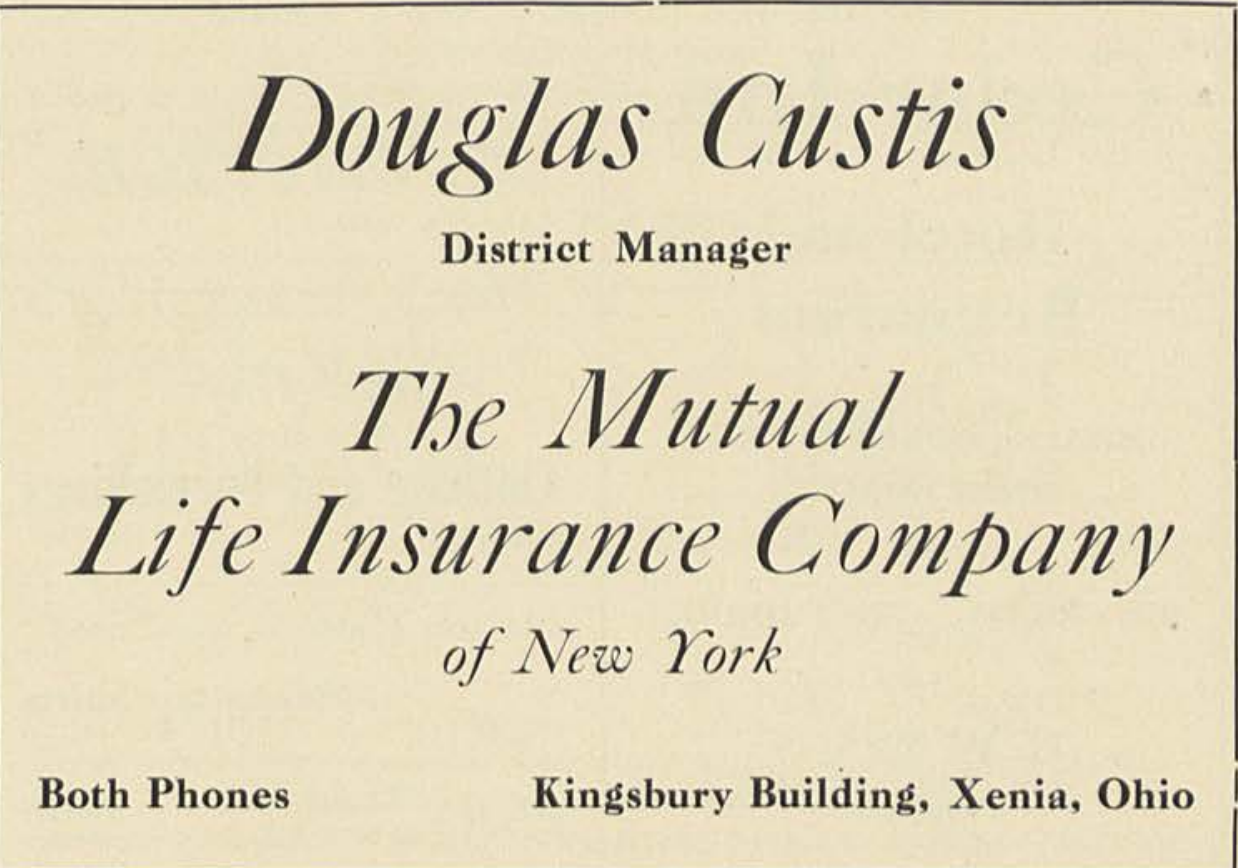




\section{The Tarbox Lumber Company}

Manufacturers of Hardwood Lumber and Retail Dealers in all kinds of

\section{Pine and Hardwood Lumber}

Shingles, Lath, Doors, Sash, Glass, Paints, Etc.

\section{Why You'll Like This Store}

You will find our sales force always eager to serve you. When they make a statement about the merehandise, you can know it is correct. We'll back every statement to the letter. You'll find a spirit of courtesy here, and an ability to please your wishes.

You'll find

\section{HART SCHAFFNER \& MARX CLOTHES}

After you buy, if you find you haven't got just what you want - money eheerfully refunded.

$$
\text { W. D. Alexander \&๐ Co. }
$$

\section{Cedar Inn}

\section{Hotel and}

Restaurant

MEALS COOKED TO SUIT

— THE PUBLIC

ICE CREAM SOFT DRINKS

H. W. EVANS

Proprietor

\section{The}

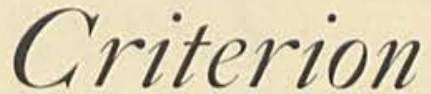

Men's, Young Men's

and Boys'

Clothing and Furnishings

Stetson Hats

Manhattan Shirts

XENIA

OHIO 


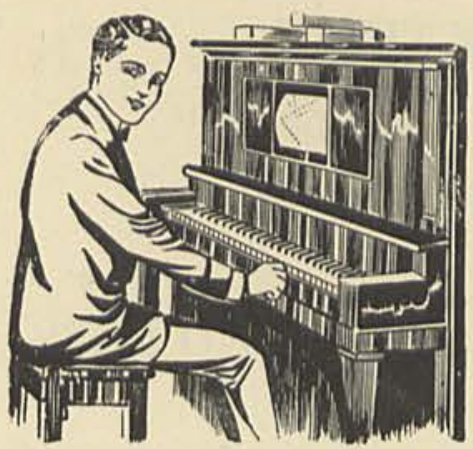

\section{WHEN THE PLAYER} ARRIVES

Nothing grows so well as a good idea, if somebody only takes the trouble to plant it. We are trying to plant in your mind the good idea of having a Player Piano in your home.

You can't be taught much of anything definite except by your own experiences. You'll never know much about the bounteous advantage of having a piano unless you buy one.

Theories are unsatisfactory. Take the plunge. Get a piano-a fine one. If you don't buy today all you lack is the view-pointwhich is all any of us lacks when we postpone a decision.

Just let a piano come into the house, and soon its music warms everybody up. The members of the household get together. Rough angles are smoothed. Grouches are lost. Everyone is happy.

\section{Sawhill-Dolbeer Company, $\begin{gathered}\text { SPINGFIELd } \\ \text { OHIo }\end{gathered}$ KNOX F. HUTCHISON, Loeal Representative}

\section{LANE THEOLOGICAL SEMINARY CINCINNATI, OHIO}

Modern Theological Curriculum, Two Courses. Elective Work leading to B. D. Degree. Co-operation with the University of Cincinnati for Graduate Work and Degree. Cosmopolitan Student Body drawn from Seven Denominations, Fifteen Colleges and Twelve States. Address

President WILLIAN McKIBBIN, D.D., LL.D.

\begin{tabular}{|c|c|}
\hline$\frac{\text { Fred. F. Graham }}{\text { DECORA TOR }}$ & $\begin{array}{c}\text { J. W. Johnson } \\
\text { Watch Repairs } \\
\text { JE W E L E R }\end{array}$ \\
\hline Xenia & Cedarville $\quad-\quad$ Ohio \\
\hline $\begin{array}{l}\text { For Classy Jewelry, } \\
\text { See } \\
\frac{\text { J. Thorb Charters }}{\text { JEWELER }}\end{array}$ & $\begin{array}{c}\text { For Eye Glass, See } \\
\text { L. A. W agner } \\
\text { Eyesight Specialist }\end{array}$ \\
\hline
\end{tabular}




\section{STANDARD ICE CREAM}

"GOODNESS,--How You'll Like It"

$$
\text { reser: }
$$

Sold in Cedarville at

\section{The Student Headquarters}

(Richard's Drug Store)

$$
\text { Dis:er: }
$$

"Eat a Plate of Ice Cream Every Day"

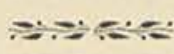

Springfield Dairy Products Co. SPRINGFIELD, OHIO

\section{MILLER TIRES}

Most talked of tire in America by giving Increased mileage making Lower cost per mile and

Less danger of tire trouble.

Every tire a record maker.

Real, genuine service.

\section{XENIA AUTO NECESSITY CO.}

XENIA, OHIO

BEFORE OR AFTER THE SHOW PAY US A VISIT

The Transfer Restaurant 


\section{"Say It With Flowers" Anderson Flower Shop \\ Xenia, Ohio \\ Wilmington, Ohio}

THE BEST HEADS THE WORLD EVER KNEW WERE WELL READ; AND THE BEST HEADS TAKE THE BEST PLACES.

-Emerson.

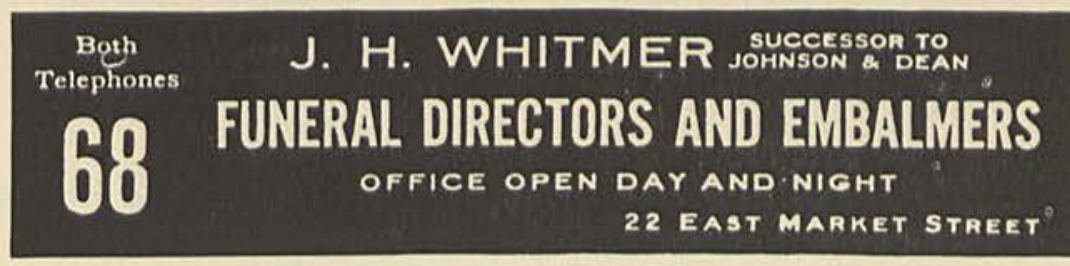

\begin{tabular}{|c|c|}
\hline Leo Anders01, D. V.M. & $\begin{array}{c}\text { W. L. Clemans } \\
\text { Real Estate, Loans } \\
\text { and } \\
\text { Veterinarian }\end{array}$ \\
$\begin{array}{c}\text { Insurance Agency } \\
\text { Established 1896 } \\
\text { Cedarville - Ohio }\end{array}$ \\
Cedarville - Ohio \\
\hline
\end{tabular}




\section{"The Bank Restaurant”}

MOTTO: The Best is None Too Good

We Have the Best

Frank G. Armstrong, Prop.

Cedarville, Ohio

The Bridge Barber Shop

Will Show You

Cedarville - - Ohio

\section{Boring's Book Store}

Stationery, Sporting Goods

Get Your Commencement Presents from Us

6 S. Detroit St. Xenia, Ohio

Why the Editor Left Town:

Somebody sent the editor of the Poketown Gazette a few bottles of home brew. The same day he received for publication a wedding announcement and a notice of an auction sale. Here are the results: "William Smith and Miss Lucy Anderson were disposed of at public auction at my farm one mile east of a beautiful cluster of roses which she carried before a background of farm implements far too numerous to mention in the presence of about seventy guests, including two milch cows, six mules and one bob sled. Rev. Jackson tied the nuptial knot with 200 feet of hay rope and the bridal couple left on one good John Deere gang plow for an extended trip with terms to suit those purchasers. They will be at home to their friends with one McCormick binder and a few kitchen utensils after ninety days from date of sale for responsible parties and some fifty chickens."

-Exchange. 
1921

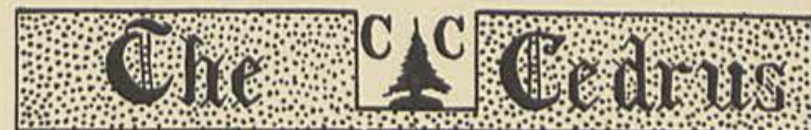

\section{FASHION PARK SPORT CLOTHES HAND TAILORED TO FIT}

All Fabrics Virgin Wool

Prices: $\$ 30$ to $\$ 55$

C. A. WEA VER

Opposite Court House

XENIA, OHIO

Adair's

FURNITURE,

CARPETS

STOVES

VICTOR VICTROLAS

20-21 N. Detroit Street

Xenia, Ohio

\section{Xenia Candy Kitchen}

"The Home of Best Candies and Ice Cream"

"We Strive to Please"

27 E. Main St. Xenia, Ohio

\section{Moser's Shoe Store Xenia, Ohio}

Good Shoes, Good Service, Good Styles We specialize on corrective fitting

XENIA VULCANIZING CO.

102 East Main St.

Xenia, Ohio

"When it is Tire Trouble,

Trouble Us"

"SPORTING GOODS"

Famous Auto Supply Co.

37 West Main Street

Xenia, Ohio
Dollars and Sense-

Will do much $-\mathrm{AT}$

\section{TROUTE'S}

Cash and Carry Grocery

CEDARVILLE

OHIO 


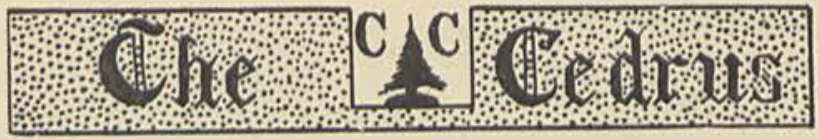

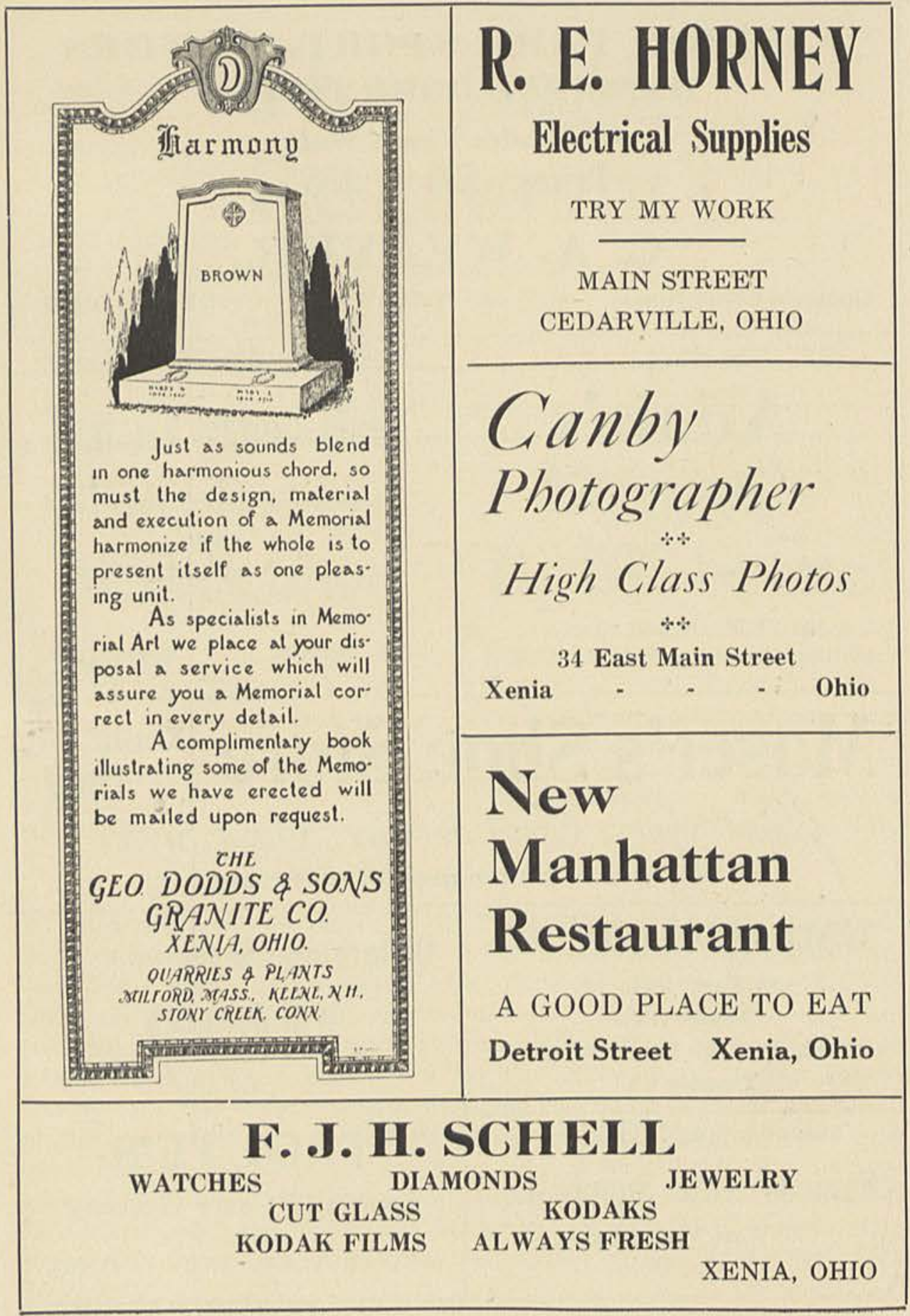




\section{1}

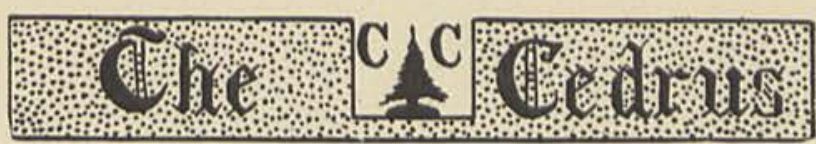

\section{Fored}

AUTHORIZED SALES AND SERVICE

R. A. Murdock

Phone 55

Cedarville, Ohio

Trust men and they will be true to you; treat them greatly and they will show themselves great.

-Emerson.

FIRST CLASS WORK - at a - FIRST CLASS SHOP

BILLY MCCOY, BARBER

Cedarville

Ohio

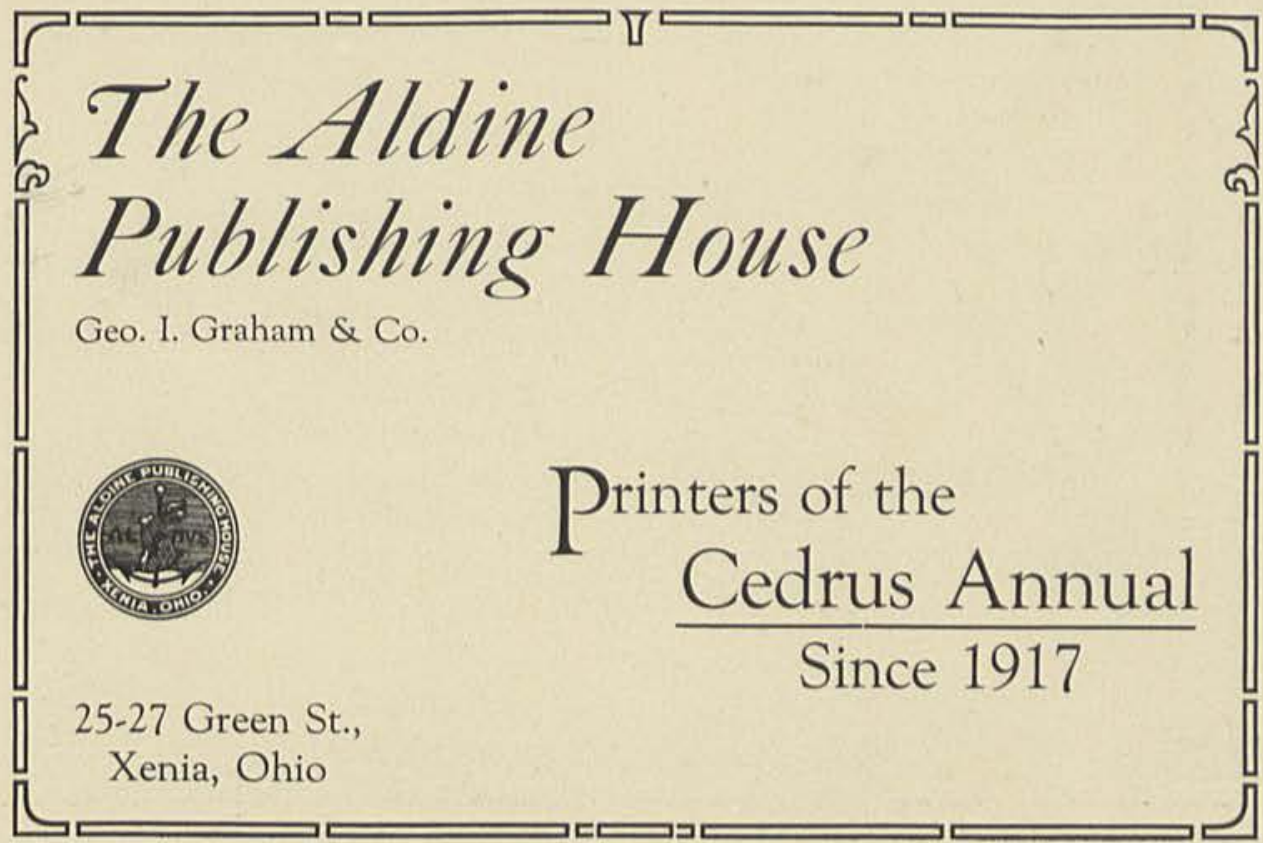




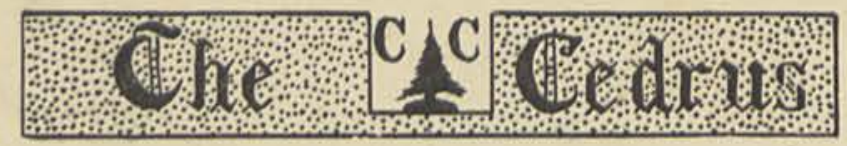

1921

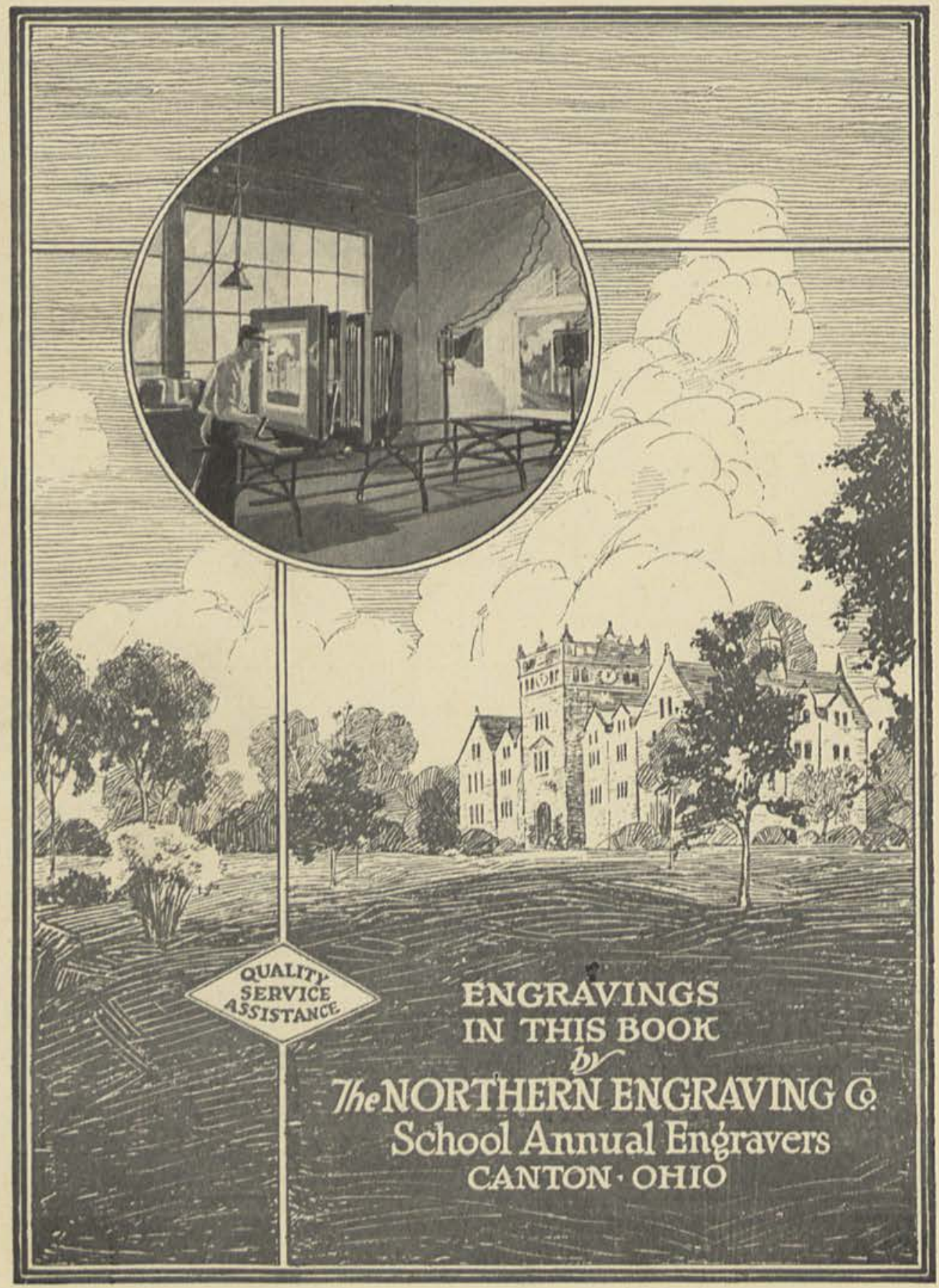




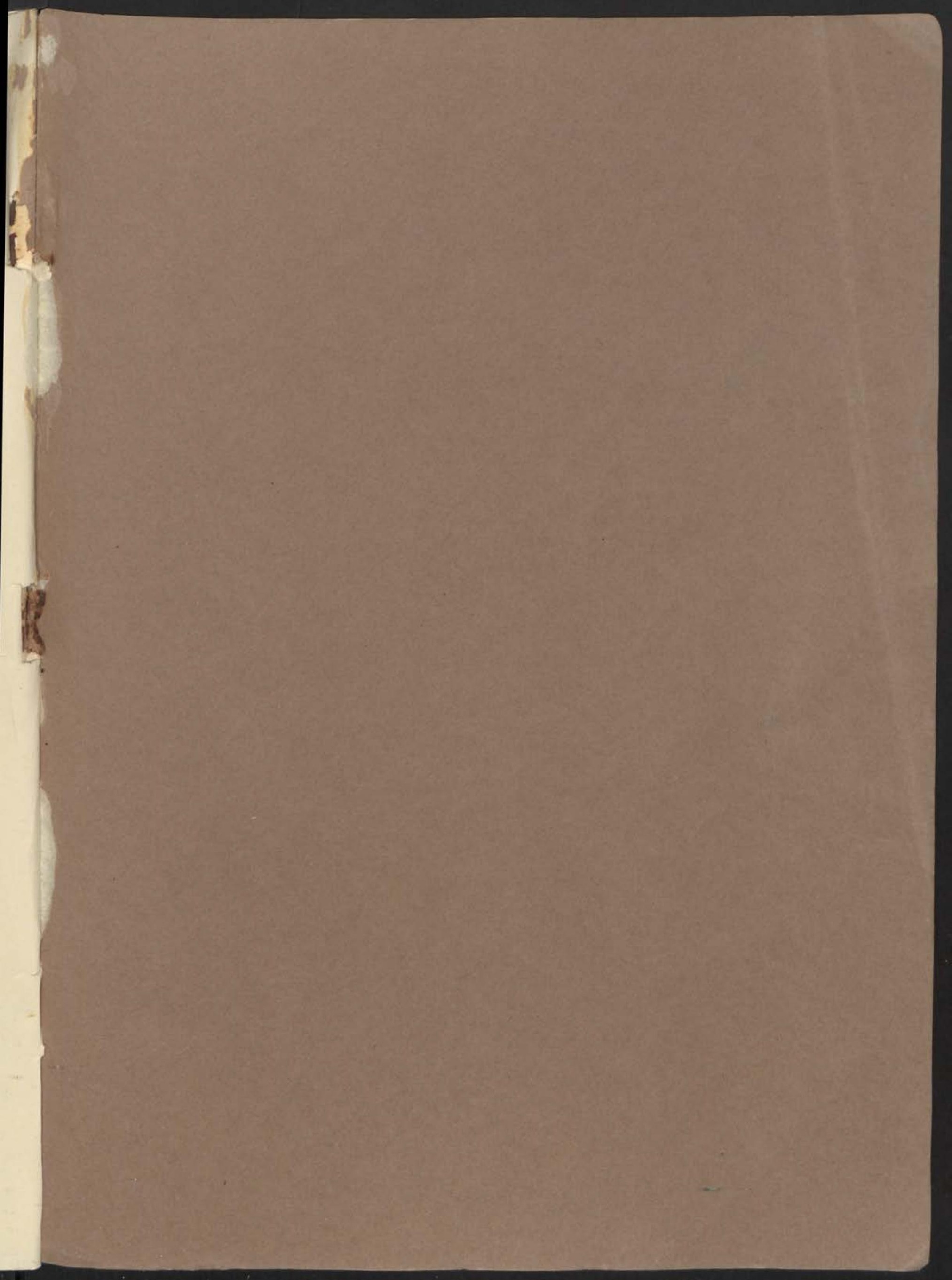


